\title{
Diffúzív és konvektív instabilitás tanulmányozása autokatalitikus reakciófrontokban
}

Doktori $(\mathrm{PhD})$ értekezés

Pópity-Tóth Éva

Témavezetôk: Dr. Tóth Ágota és Dr. Horváth Dezső

Kémia Doktori Iskola

SZTE TTIK

Fizikai Kémiai és Anyagtudományi Tanszék

Szeged, 2012 


\section{Tartalomjegyzék}

1. Bevezetés 1

2. Irodalmi áttekintés 4

2.1. A diffúzív instabilitás elméleti háttere és kísérleti megvalósítása . . . . . . 4

2.2. A konvektív instabilitás kialakulásának lehetőségei . . . . . . . . . . . . 6

2.3. A vizsgált autokatalitikus reakciók . . . . . . . . . . . . . . . 9

2.3.1. A klorit-tetrationát rendszer . . . . . . . . . . . . . . . . 99

2.3.2. A jodát-arzénessav rendszer . . . . . . . . . . . . . . 10

2.4. A diffúziós együttható meghatározása NMR segítségével . . . . . . . . . . 12

3. Célkitúzés 15

4. Kísérleti rész 17

4.1. Oldat- és gélkészítés . . . . . . . . . . . . . . . . 17

4.2. A kísérleti elrendezések . . . . . . . . . . . . . . . . . . . . . . . 19

4.3. Az alkalmazott kísérleti mérốmódszerek . . . . . . . . . . . . . . . . 23

5. Kiértékelési módszerek 26

5.1. A frontprofil és a frontsebesség meghatározása . . . . . . . . . . . . 26

5.2. Diszperziós görbe meghatározása . . . . . . . . . . . . . . . . 27

5.3. A keveredési hossz és az átlagos frontalak definiálása . . . . . . . . . . . . 29

5.4. Spektrumanalízis . . . . . . . . . . . . . . . 30

6. Eredmények 32

6.1. A laterális instabilitás hatása az autokatalitikus frontra . . . . . . . . 32

6.1.1. A mintázatképződés eredményei . . . . . . . . . . . . . 32

6.1.2. Az NMR-mérés eredményei . . . . . . . . . . . . . . . . . 36

6.2. A konvektív instabilitás hatása . . . . . . . . . . . . . . . . . . 41

6.2.1. A skálázási törvény érvényessége . . . . . . . . . . . . . . 41

6.2.2. Háromdimenziós szerkezet tanulmányozása . . . . . . . . . . . . . 47 
6.3. Marangoni instabilitás kísérleti megvalósítása . . . . . . . . . . . . . 52

6.3.1. A klorit-tetrationát reakció esetén kapott eredmények . . . . . . . . 52

6.3.2. Az instabilitás jodát-arzénessav reakcióban történő kimutatása . . . 57

6.3.3. Egyéb reakciók eredményei . . . . . . . . . . . . . . 64

7. Összefoglalás 66

$\begin{array}{ll}\text { 8. Summary } & \mathbf{7 0}\end{array}$

Irodalomjegyzék $\quad \mathbf{7 4}$

Köszönetnyilvánítás $\quad 81$ 


\section{1. fejezet}

\section{Bevezetés}

Nem is hinnénk, hogy a minket körülvevő világban milyen nagy jelentőséggel bírnak a különböző transzportfolyamatok, amelyek során az anyag, az energia, a töltés vagy valamilyen más extenzív jellegú mennyiség egyik helyrôl a másik helyre képes eljutni [1]. Ezek, a természeti jelenségek mozgatórugójaként a mindennapi életünkre is igen nagy befolyással vannak. Gondoljunk csak a 2005 augusztusában New Orleansban pusztító Katrina hurrikánra (1.1. (a) ábra), vagy a 2010-es mexikói-öbölbeli olajkatasztrófára, amelynek következtében több millió nyersolaj ömlött és terjedt szét a tengervízben (1.1. (b) ábra), és ezáltal ökológiai katasztrófát okozott az állat- és a növényvilágban. Szintén 2010-ben történt, hogy Izlandon múködésbe lépett az Eyjafjallajökull vulkán (1.1. (c) ábra), amelynek hatására az európai légi közlekedés megbénult. Sajnos nem kell messzire menni hasonló példák felkutatása miatt, mert ugyan ebben az évben következett be Magyarországon az ajkai vörösiszapkatasztrófa is. Szerencsére nem csak tragédiáknál múködnek közre a transzportfolyamatok, hanem számos egyéb jelenségnél is fellelhetők, mint például a felhők képződésénél. Az erôs

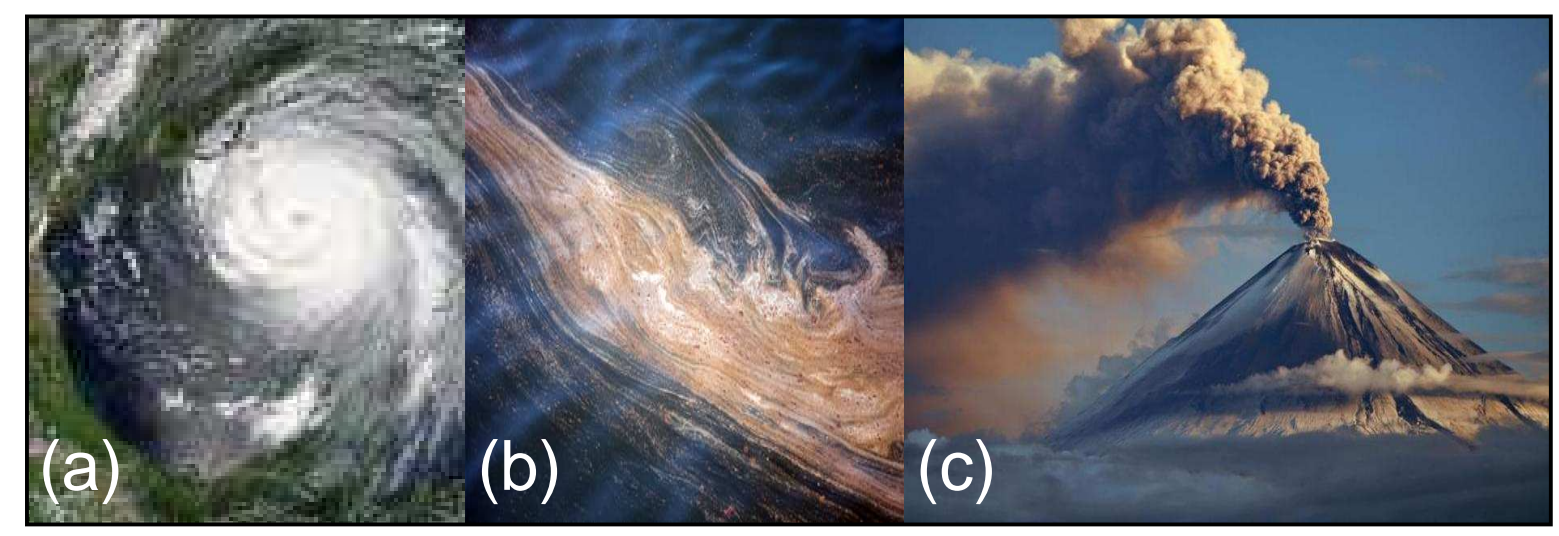

1.1. ábra. A Katrina hurrikán felülnézeti képe (a), az olajszennyeződés szétterjedése a víz felszínén (Mexikói-öböl) (b), az izlandi Eyjafjallajökull vulkán képe (c) [2]. 
napsugárzás hatására a földfelszín közelében lévő, vízgőzt tartalmazó légréteg felmelegszik, és ennek következtében a magasba áramlik, ahol lehúl. Ha a hőmérséklet egy kritikus érték alá csökken, akkor különböző típusú légköri képződmények (bárányfelhő, zivatarfelhő, gomolyfelhő stb.) jönnek létre a kicsapódó vízgőz hatására. Ugyanez a jelenség a hajtóereje az idôjárási frontok és a különféle áramlatok kialakulásának is. Meg kell említeni még a kontinensek elmozdulását a forró, képlékeny magmán a tektonikus mozgások hatására, valamint a láva felszínre jutásának eredményét. A sort még számos példa bemutatásával lehetne folytatni.

Körülményektől függően további heterogén rendszerekben is igen változatos mintázatok létrejöttét figyelhetjük meg, mint például a csapadékképződéssel járó reakciók és a diffúzió kölcsönhatása révén kialakuló csíkos Liesegang-szerkezetek [3], illetve az ozmotikus hatások következtében létrejövő szilikátnövények [4]. A természetben is sok hasonló példát fedezhetünk fel: az állatok kültakarója, az ásványok és a kőzetek mintázatai, a cseppkövek.

Mivel ezek a jelenségek a természet eróinek a megnyilvánulásakor igen erôteljesen hatnak ránk, ezért elengedhetetlen a kísérleti tanulmányozásuk. Az anyagtranszport, azaz a részecskék helyváltoztatása leginkább koncentrációgradiens hatására létrejövő diffúzió révén, a gravitációs erőtérben kialakuló közegmozgás következtében, valamint külső elektromos tér által ionokra gyakorolt migrációval valósulhat meg.

A munkám során többféle autokatalitikus reakciót is vizsgáltam. Autokatalízisről akkor beszélhetünk, amikor egy reakció során valamelyik képződött termék a reakció katalizátora. Ez az egyik legegyszerúbb nemlineáris kémiai jelenség. A nemlineáris szó ebben az esetben azt jelenti, hogy mind a koncentrációkban, mind pedig a reakciók sebességében nem egyenes arányosság szerinti változás, hanem egy hirtelen, ugrásszerú módosulás jön létre, illetve bizonyos változások periodicitását lehet megfigyelni. Az ilyen jelenségeknél a koncentrációk a megszokottól eltérôen, vagyis nemmonoton módon változnak. Ide tartozik az oszcilláció, a káosz és a mintázatképződés is [5].

Az autokatalitikus kémiai reakciók és az anyagtranszport kölcsönhatása egy éles határvonal kialakulását eredményezi a termékek és a reaktánsok között, amelynek a két oldalán állandó sûrúségkülönbség jön létre. Ezt a bizonyos határvonalat, amely egy autokatalitikus reakció tér- és időbeli lejátszódásakor alakul ki, kémiai frontnak nevezzük. A határfelület a vándorlása során a körülményektől függően homogén közegben haladva általában megőrzi az eredeti sík alakját, vagyis stabilis. Bizonyos körülmények között viszont a reaktánselegyben haladó síkfront stabilitását elveszítve, a kísérleti zajok felerôsödéséből, elôrehaladó és lemaradó szegmensekkel jellemezhető cellás szerkezetek jöhetnek létre [6].

A különbözô kísérleti körülmények között a reakcióban fejlődő autokatalizátor diffúziójának az eredményeképpen kialakuló reakció-diffúzió frontok instabilitását tanulmányoztam, hogy a kapott eredményekbőll levont következetésekkel sikeresen vehessünk részt az Európai 
Û́rkutatási Ügynökség (ESA) mikrogravitációs kísérleteiben. Az egyszerúbb jelenség vizsgálata után - mikor csak a diffúzió volt jelen - tértem át az összetettebbre - a diffúzió mellett már a konvekció is fellépett -, amelynek a teljes megértéséhez szükségesek a súlytalanság állapotában végrehajtott kísérletek eredményei is. 


\section{2. fejezet}

\section{Irodalmi áttekintés}

\subsection{A diffúzív instabilitás elméleti háttere és kísérleti meg- valósítása}

Az olyan frontinstabilitást, amikor a front haladási irányára merőlegesen alakul ki a stabilitásvesztés, laterális instabilitásnak nevezzük. Ha konvekciómentes közegben a diffúzióbeli különbségek okozzák ezt a jelenséget, akkor diffúzív instabilitásról beszélhetünk. A síkfront homogén közegben haladva attól függően válik stabillá, illetve instabillá, hogy hogyan viszonyul egymáshoz a reaktánsok és az autokatalizátor diffúziós együtthatója.

Elmondható, hogy a diffúzív instabilitás létrejöttéhez két feltétel egyidejú teljesülése szükséges. Az első az, hogy az autokatalízis megfelelő erősségú legyen, vagyis, az adott reakcióra vonatkozó sebességi egyenletben az autokatalizátor részrendjének mindig egynél nagyobbnak kell lennie. A második pedig az, hogy az autokatalizátor fluxusa kisebb legyen a reaktánsokénál $[6,7]$. A fluxust nemcsak a $D$ diffúziós koefficiens, hanem a front menti koncentrációváltozás is befolyásolja. Az ilyen körülmények között észlelhető laterális frontinstabilitás megvalósulását mutatja be a 2.1. ábra [8]. Az ábrán egy $\mathrm{A}+2 \mathrm{~B} \longrightarrow 3 \mathrm{~B}$ (azaz $\mathrm{A} \longrightarrow \mathrm{B}$ ) köbös autokatalitikus reakció frontprofiljának sematikus rajza látható, ahol A a reaktáns, B pedig az autokatalizátor. A kezdetben viszonylag sík frontalak a reakció előrehaladtával felhasad, és ez cellás szerkezet kialakulását eredményezi. Ha a frontalakzat csak kicsiny részletére fókuszálunk, akkor láthatóvá válik, hogy a front mikroszkopikusan egyenetlen, mivel mindig van a rendszerben kísérleti zaj. Az előrehaladó frontrészlet mentén az autokatalizátor koncentrációja lokálisan kisebb lesz a síkfronthoz képest, hiszen nagyobb térrészbe diffundál, vagyis a reakciófront lassabb lesz a síkfronthoz viszonyítva. A lemaradó frontszegmens mentén viszont azt tapasztaljuk, hogy mivel a B kisebb térrészbe diffundál, a reakciófront elôrehaladása lokálisan felgyorsul a reakció sebességének nagyobb mértékú növekedésével. A reaktáns diffúziója éppen ellenkezőleg hat, és ennek hatására ez a folya- 


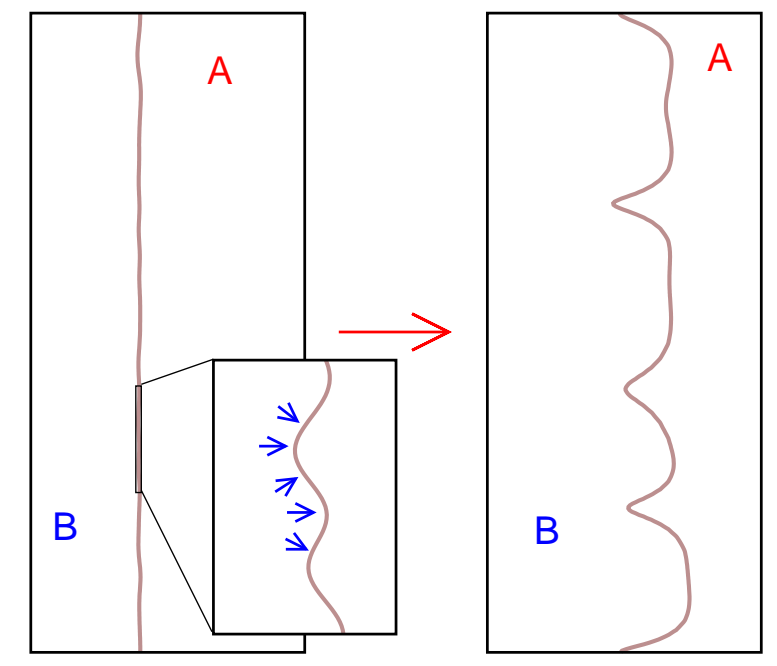

2.1. ábra. $\mathrm{Az} \mathrm{A}+2 \mathrm{~B} \longrightarrow 3 \mathrm{~B}$ kémiai front stabilitásvesztésének szemléltetése, amikor a front balról jobbra halad.

mat tovább növeli a kezdeti torzulásokat. Összegezve elmondható, hogy a B diffúziója révén igyekszik stabilizálni a síkfrontot, az A pedig destabilizálni. A két ellentétes válaszreakció egymással verseng, és ha a reakcó előrehaladtával a reaktáns által okozott változás válik dominánssá az autokatalizátoréval szemben, akkor a kezdeti, planárisnak tekinthető frontból cellás szerkezet fejlódik ki.

Ma már többféle lehetôség is a rendelkezésünkre áll arra, hogy az előzőkben ismertetett feltétel teljesüljön. Olyan esetben, amikor eredetileg az autokatalizátor diffúziója nem lassabb a reaktánsokénál, vagy le kell lassítani, azaz részlegesen meg kell kötni az autokatalizátort [9-12], vagy a reaktánst kell felgyorsítani inhomogén elektromos erótérben [13]. Az előbbi eset elsô kísérleti megvalósítása a jodát-arzénessav rendszerben történt a jodidion megkötésével pufferált közegben. Ennek a kivitelezéséhez $\alpha$-ciklodextrint alkalmaztak, és az így kialakult torzult frontot körülbelül két centiméteres cellák alkották [9]. Ekkor még a mintázatokat csak pár milliméternyi amplitúdóval lehetett létrehozni. Ennél jóval nagyobb, centiméteres nagyságrendú cellás mintázatot sikerült találni a klorit-tetrationát sav katalizált rendszerben $[10,12]$. A gyorsabban diffundáló hidrogéniont immobilis karboxilátcsoportokat tartalmazó vegyület alkalmazásával kötötték meg reverzibilisen az alábbi egyenlet alapján:

$$
\mathrm{H}^{+}+-\mathrm{COO}^{-} \rightleftharpoons-\mathrm{COOH}
$$

ahol a reaktánsok diffúziója továbbra is akadálymentes marad. A (2.1) egyenletből kitúnik, hogy ha növeljük a karboxilátcsoportok számát, akkor az a szabad hidrogénion-koncentráció csökkenését vonja maga után azáltal, hogy a hidrogénion fluxusa kisebb lesz, vagyis bizonyos karboxilát koncentráció felett frontinstabilitás lép fel. A kívánt mértékű fluxuscsökken- 
tés a gélbe polimerizált nátrium-metakrilát [10,12] vagy pedig poli(nátrium-metakrilát) [14] révén érhetô el. Megfelelố nagyságú és irányú állandó elektromos erőtér alkalmazása szintén lehetővé teszi a cellás szerkezet kialakulását a front mögötti koncentrációk változtatásával [15].

\subsection{A konvektív instabilitás kialakulásának lehetôségei}

A közegmozgást három tényező, a sûrúségkülönbség, a viszkozitás és a felületi feszültség változása befolyásolja. Az elkövetkezendőkben mindhárom esetet szeretném részletesebben is kifejteni. Először is vizsgáljuk meg a két, egymásra rétegzett és egymással nemelegyedő, eltérő sûrúségú folyadék között kialakuló határfelület viselkedését gravitációs térben. Abban az esetben, ha a nagyobb sưrüségú folyadékra helyezzük a kisebb sưrűségút, akkor a kezdetben sík határvonal megő́rzi hidrodinamikai stabilitását. Az eset fordítottja sokkal izgalmasabb, hiszen ekkor lehetőség nyílik a közegmozgás kialakulására. Ennek a jelenségnek az elméleti hátterét még 1883-ban Rayleigh jegyezte le [16]. Az 1900-as évek közepén ezt a munkát folytatva Taylor a gyorsulás hatására bekövetkező határfelületi stabilitásvesztés elméletét kutatta [17]. Éppen ezért ma a gravitációs erőtér hatására a sûrúségkülönbség miatt fellépő stabilitásvesztést Rayleigh-Taylor instabilitásnak nevezik. Mindezt kísérleti úton pedig Lewis vizsgálta meg víz-benzol, víz-glicerin és víz-szén-tetraklorid rendszerekben [18].

Azonos feltételek mellett, csak különböző viszkozitású folyadékok esetében Taylor és Saffman tárta fel a jelenség kémiáját [19]. A viszkozitáskülönbség miatt létrejövő közegmozgást Saffman-Taylor instabilitásnak szokás nevezni, bár a jelenséget igazából elsôként Hill publikálta [20]. A viszkozitás változására létrejövő mintázatok elméleti modellezésre csak az 1990-es években került sor [21,22]. A hatás vizsgálata kutatócsoportunk érdeklődését is felkeltette [23].

Sưrűségkülönbség hő hatására is létrejöhet, és ekkor beszélhetünk Rayleigh-Bénard instabilitásról [24]. A jelenség első kísérleti megfigyelését Bénard végezte el, míg a stabilitásvesztéssel Rayleigh foglalkozott. Bénard a kísérlet során egy fúthetô fémlapra még a milliméternél is vékonyabb olajréteget helyezett el vízszintesen. Megfigyelte, hogy az olajréteg levegővel érintkező felületén fütés hatására hexagonális rács alakú mintázat alakult ki. Ennek az volt a különlegessége, hogy a szabályos hatszögek közepén az olajfelszín bemélyedt, szélein viszont kiemelkedett. Ez azért következik be, mert a forró fémfelszínnel érintkező meleg folyadékrész a kisebb sûrúsége miatt felfelé áramlik, viszont a nagyobb súrúségú, levegôvel közvetlenül határos rész lefelé halad, és így konvekciót indukál.

A kapillárisokban haladó reakció-diffúzió frontok tanulmányozása után az mondható el, hogy a frontok terjedésének sajátosságai függnek a haladásuk irányától és a cső átmérőjétől is [25-27]. Megállapítható, hogy a gravitációnak igen jelentős szerepe van a mintázatkép- 
ződésre. Töltet nélküli csövekben növelve az edény keresztmetszetét, a kezdeti sík alak valamilyen irányba torzul [28-30]. A 2.2. ábra segíti a jelenség megértését, mikor a nagyobb sûrûségû folyadék a kisebb sûrúségű folyadék felett helyezkedik el. Az alkalmazott kísérleti reakcióedény geometriai paraméterei nagy hatással vannak a közegmozgásra, hiszen azok befolyásolják a konvekció mértékét. A legvékonyabb csőben a front előrehaladása során mindvégig megôrzi sík alakját az adott súrúségkülönbség ellenére is, mivel a közegmozgáshoz nincs elegendô tér, egyetlen egy konvekciós gyưrú kialakulásának sincs hely. A csőátmérô növekedésével először aszimmetrikus, majd szimmetrikus alakzatok fejlődnek ki azáltal, hogy a nagyobb sûrúségú folyadék belesüllyed a kisebb sûrúségú folyadékba. A mintázat függ attól, hogy hány konvekciós gyưrú kifejlődésére van elegendő hely.

Az exoterm reakciók során bekövetkező hőtermelődés szintén sưrűségváltozást idéz elő, és így nagyobb lesz a reakciófront menti keveredés, aminek a hatására nő a frontok sebessége [31-33]. A klorit-tioszulfát rendszer vizsgálatakor azt is megállapították, hogy adott cső́atmérô esetében a frontsebesség hogyan függ a cső orientációjától, a függőlegestől való megdöntésétől [26]. Cellás szerkezet létrejöhet a kémiai összetétel változásából adódó súrűségkülönbség $\left(\Delta \rho_{c}\right)$ miatt, valamint a folyamatot kísérő hőmérséklet-változás okozta sûrúségváltozás $\left(\Delta \rho_{T}\right)$ eredményeképpen. Egyszerú konvekcióról van szó abban az esetben, ha a $\Delta \rho_{c}$ a meghatározó [28]. Ha a $\Delta \rho_{c}$ és a $\Delta \rho_{T}$ összemérhetővé válik, akkor már összetett konvekcióval állunk szemben [31].

A kutatók élen jártak a kísérletek elméleti hátterének megteremtésében is. Kezdetben Huang és Edwards azt tételezte fel, hogy egy kémiai reakció két különböző sûrúségú folyadék esetében csak egy nagyon vékony front mentén játszódik le [34,35]. A vékonyfrontközelítés helyett ma már elhanyagolásmentesen a teljes frontot veszik figyelembe az elméleti számításoknál. Ezen elgondolások mellett De Wit és munkatársai leírták már a RayleighTaylor instabilitásnak, azon belül is leginkább a konvekciónak, a mintázatra gyakorolt hatá-
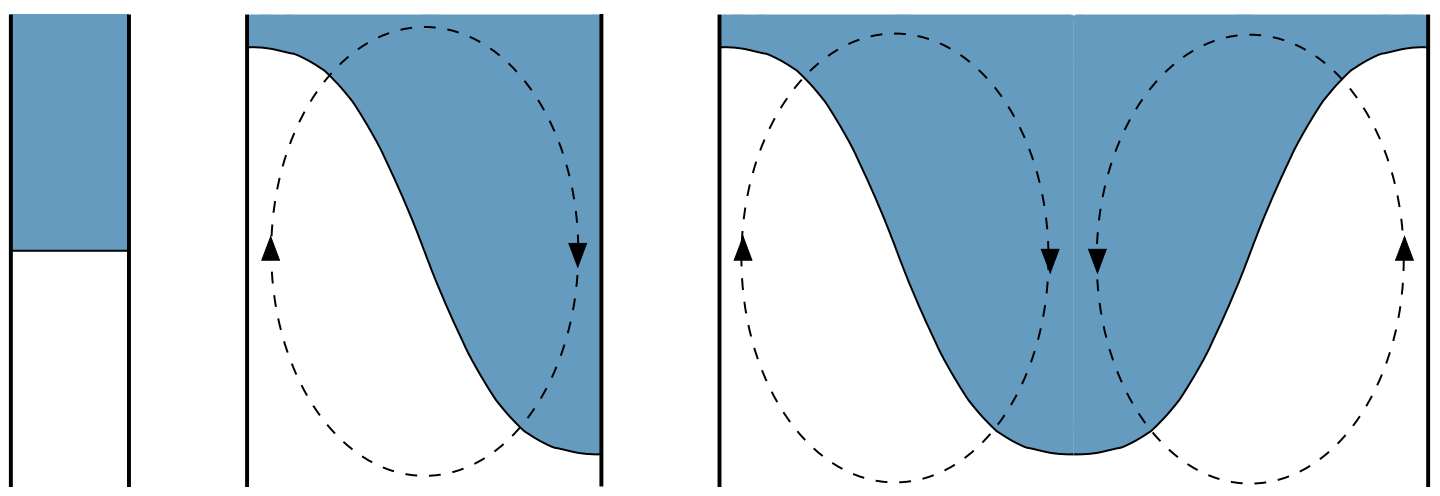

2.2. ábra. A csőátmérő növekedésével létrejövő frontalakok. Felül helyezkedik el a nagyobb sûrűségú oldat, míg alul a kisebb súrúségú. Az ellipszisek a konvekciós gyưrúket jelképezik. 
sát [36-40]. A mennyiségi leírás fejlődése lehetővé tette a számolások és az empirikus vizsgálatok közti kapcsolat létrejöttét. A kezdeti mintázatképződés jellemzésére a diszperziós összefüggés használata vált elterjedtté [41], ami a komponensek növekedési együtthatóinak hullámszámtól való függését jelentette. A kialakult mintázatok továbbalakulásának jellemzésére már az alakzatok torzulását mennyiségileg jellemzô keveredési hossz értéke bizonyult a legmegfelelőbbnek [43].

A Marangoni instabilitás szintén a közegmozgás egyik megnyilvánulásának a lehetősége, ami a felületi feszültséggradiens hatására létrejövő anyagátvitel következtében lép fel a folyadék/gáz határvonal mentén. Ennek az a lényege, hogy a nagyobb felületi feszültségú folyadék magára húzza a kisebb felületi feszültségú folyadékot a határfelületnél. Ezt a jelenséget 1855-ben azonosították a "bor könnyeként", de először csak 1865-ben publikálta Marangoni olasz származású fizikus, és éppen ezért róla nevezték el. A bor az alkohol és a víz elegye. Az alkohol párolgása gyorsabb, és a felületi feszültsége is kisebb a vízénél, ezért a pohár falánál, a levegő határfelületnél a borban az alkohol koncentrációja kisebb lesz, mint a belsô, tömbfázis esetén. Az itt előforduló oldatréteg vízben töményebb, nagyobb a felületi feszültsége, és a Marangoni jelenség hatására ebbe az irányba a kisebb felületi feszültségú belsô rétegek felől folyadékáramlás következik be. A folyadékszint megemelkedik a pohár falánál, majd egy idő után a cseppek a saját súlyuknál fogva visszazuhannak a tömbfázisba. Ez a határfelületi jelenség egy boros pohár oldal-, valamint felülnézeti képén látható leginkább, amit a 2.3. ábra mutat be.
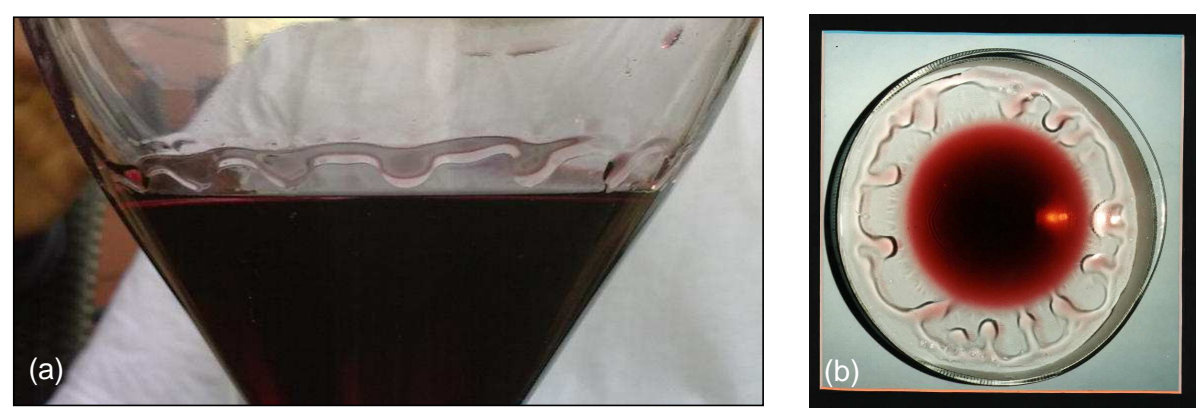

2.3. ábra. Egy boros pohár oldal- (a), illetve felülnézeti képe (b) [42].

Rongy és De Wit a jelenség elméletét már számos szemszögból megvizsgálta [44, 45], és lejegyezte. Kísérletileg ezt vízszintesen haladó reakció-diffúzió frontok esetében lehet jól tanulmányozni [46]. Vegyünk egy függőleges térállású reakcióedényt, amelyben vékony oldatréteg esetén a vízszintesen haladó stabil reakciófront elveszítheti stabilitását, ha más a reaktáns és a termék sûrúsége. Ha nem lenne sûrúségbeli különbség a reaktáns- és a termékoldat között, akkor a kezdeti sík front a reakció előrehaladása során végig megốrizné a sík alakját, ahogyan azt a 2.4. (a) ábra szemlélteti. Elmondható a kísérleti tapasztalatok alapján, hogy ahogy nô az edény magassága, úgy növekszik a mennyiségi leírásra szolgáló keveredési 

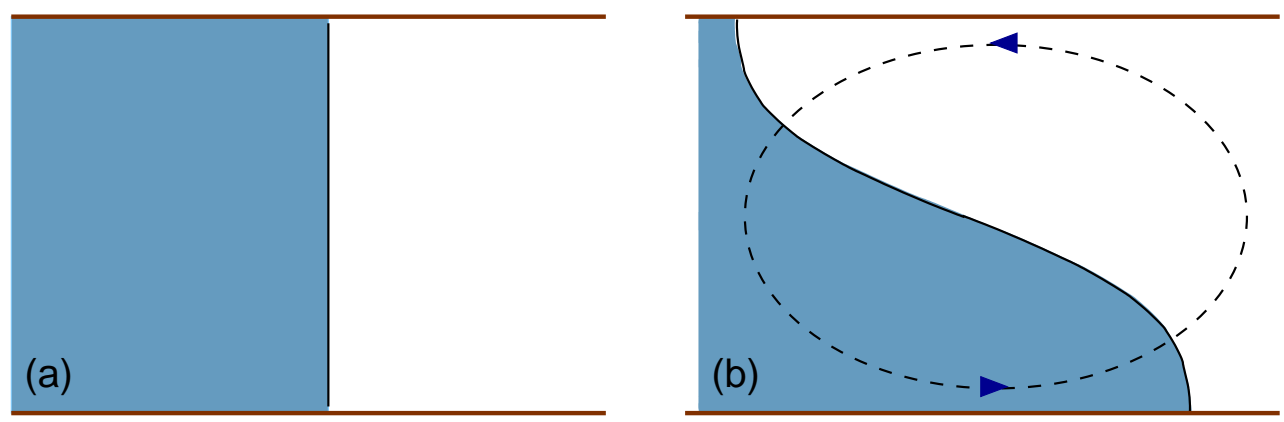

2.4. ábra. Balról jobbra haladó függóleges reakciófront sematikus rajza. Baloldalt helyezkedik el a kék színú, nagyobb sûrúségú termék, míg jobboldalt a kisebb súrúségú reaktánsoldat.

hossz értéke is. A kezdeti sík front elveszíti a stabilitását, mivel a gravitációs mező hat rá, és ennek a következtében a nagyobb súrúségú termékelegy alá csúszik a kisebb sûrúségú reaktánselegynek (lásd a 2.4. ábrán). Ha olyan anyagot adunk a rendszerhez, ami megváltoztatja a kezdetben fennálló egyenlőséget a felületi feszültség értékek között, akkor a reakciófront a 2.5. (a) vagy (b) ábra szerint módosul úgy, hogy az növeli vagy csökkenti a termékoldat felületi feszültségét $\left(\gamma_{t}\right)$, vagy éppen ellenkezőleg a reaktánsoldat felületi feszültségét $\left(\gamma_{\mathrm{r}}\right)$ változtatja meg.
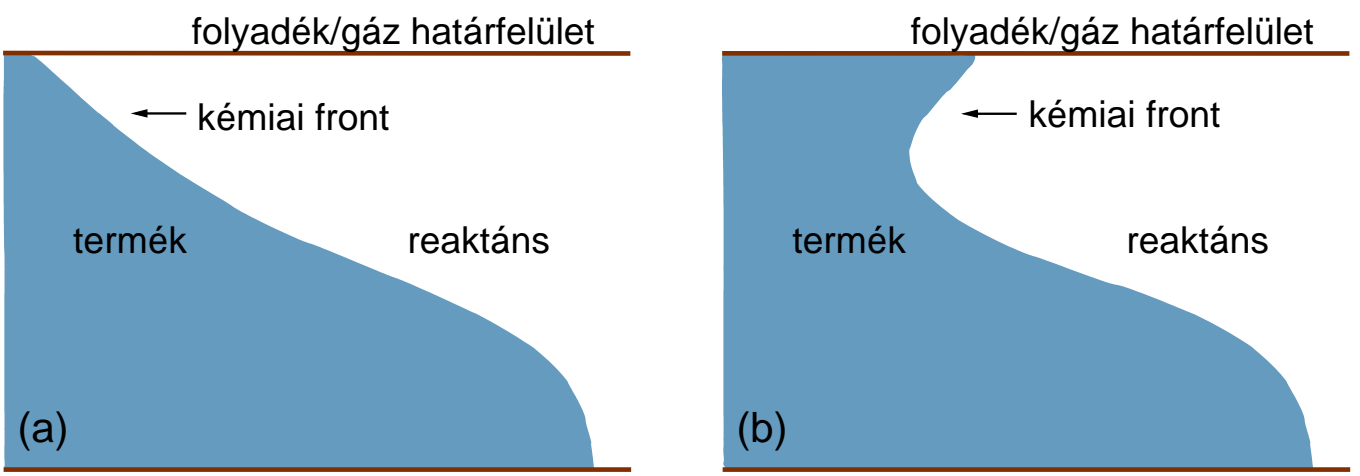

2.5. ábra. A reakciófront deformálódása, ha a $\gamma_{t}>\gamma_{r}$ (a), illetve ha a $\gamma_{t}<\gamma_{r}$ (b).

\subsection{A vizsgált autokatalitikus reakciók}

\subsubsection{A klorit-tetrationát rendszer}

A hidrodinamikai instabilitás egyik modellreakciója, amikor a tetrationátion klorition hatására oxidálódik. A csoportunkban régóta foglalkoznak ezen reakció kísérleti tanulmányozásával [47]. A klorit-tetrationát (CT) autokatalitikus reakció egy savas frontreakció [48], amellyel egyszerú dolgozni, és jól reprodukálható eredményeket ad. A reakció lejátszódá- 
sát nagymértékben befolyásolja a reaktánsok kiindulási koncentrációjának aránya, és ez a végbemenő teljes mechanizmust is megváltoztatja [49]. Kis kloritionfelesleg szükséges a következő bruttó reakció lejátszódásához:

$$
7 \mathrm{ClO}_{2}^{-}+2 \mathrm{~S}_{4} \mathrm{O}_{6}^{2-}+6 \mathrm{H}_{2} \mathrm{O} \rightarrow 7 \mathrm{Cl}^{-}+8 \mathrm{SO}_{4}^{2-}+12 \mathrm{H}^{+}
$$

Valójában ez a folyamat a legkedvezőbb termodinamikai szempontból. Ez csak a klorités a tetrationátion közti reakció kezdeti szakaszát írja le. A teljes mechanizmus nagyon összetett [50,51], több reakciólépésen keresztül jutunk el a végtermékekhez. A folyamat reakcióentalpiáját $\Delta_{\mathrm{r}} \mathrm{H}=-3960 \pm 50 \mathrm{~kJ} / \mathrm{mol}$-nak határozták meg [47]. Az 1986-ban az órareakciók tanulmányozásakor megalkotott sebességi egyenlet az előző bruttó reakcióra a következő [52]:

$$
\mathrm{r}=-\frac{1}{7} \frac{\mathrm{d}\left[\mathrm{ClO}_{2}^{-}\right]}{\mathrm{dt}}=\mathrm{k}_{\mathrm{CT}}\left[\mathrm{ClO}_{2}^{-}\right]\left[\mathrm{S}_{4} \mathrm{O}_{6}^{2-}\right]\left[\mathrm{H}^{+}\right]^{2}
$$

ahol a $k_{C T}$ sebességi együttható értéke $10^{9} \mathrm{M}^{-3} \mathrm{~s}^{-1}$.

Az empirikus sebességi egyenletből látszik, hogy a diffúzív instabilitás kimutatásának első feltétele teljesül, vagyis az autokatalizátor - ami a jelen esetben a hidrogénion - részrendje kettô. A második feltétel alapesetben nem teljesül, de ahogyan azt már a 2.1 fejezetben írtam, a megvalósítására már számos lehetőség fennáll.

A reakció során sưrúségváltozás következik be, méghozzá úgy, hogy a képződött termékoldat sû́rúsége nagyobb lesz a kiindulási reaktánséhoz képest. A folyamat során fellépő exotermicitás viszont a reakciófront közelében hőmérséklet-emelkedést idéz elő, ami lokális sûrűségcsökkenéshez vezet. Ennek köszönhetően megfelelő körülményeket biztosítva ebben a reakcióban az egyszerú és az összetett konvekció is nyomon követhetô. Számos paraméter változtatásának kísérleti hatását vizsgálták már meg a CT reakció esetében, mint például az edény orientációjának, az oldatréteg vastagságának, a hőelvonásnak, a kiindulási koncentráció változtatásának és az edény periodikus modulációjának a hatását [47,53-55].

\subsubsection{A jodát-arzénessav rendszer}

A másik, a csoportunk által is sokat tanulmányozott modellreakció, az arzénessav jodátionnal történő oxidációja (IAA). Az elég régóta ismert reakció [56] többféle bruttó reakció szerint mehet végbe a jodátionok és az arzénessav kezdeti koncentrációjának arányától függően.

$\mathrm{Ha}[\mathrm{As}(\mathrm{III})]_{0} /\left[\mathrm{IO}_{3}^{-}\right]_{0} \leq 2,5$, mikor a jodátion sztöchiometriai feleslegben van, és a végtermék jód, akkor a bruttó reakció [57]:

$$
2 \mathrm{IO}_{3}^{-}+5 \mathrm{H}_{3} \mathrm{AsO}_{3}=\mathrm{I}_{2}+5 \mathrm{H}_{2} \mathrm{AsO}_{4}^{-}+\mathrm{H}_{2} \mathrm{O}+3 \mathrm{H}^{+} .
$$

$\mathrm{Ha}[\mathrm{As}(\mathrm{III})]_{0} /\left[\mathrm{IO}_{3}^{-}\right]_{0} \approx 8 / 3$, amikor egyik komponens sincs feleslegben, és a végtermék a 
$\mathrm{I}_{2}+\mathrm{I}^{-}=\mathrm{I}_{3}^{-}$reakció során képződött trijodidion, akkor a bruttó reakció a következő:

$$
\mathrm{IO}_{3}^{-}+8 \mathrm{H}_{3} \mathrm{AsO}_{3}=\mathrm{I}_{3}^{-}+8 \mathrm{H}_{2} \mathrm{AsO}_{4}^{-}+3 \mathrm{H}_{2} \mathrm{O}+6 \mathrm{H}^{+}
$$

Ha viszont $[\mathrm{As}(\mathrm{III})]_{0} /\left[\mathrm{IO}_{3}^{-}\right]_{0} \geq 3$, mikor az arzénessav van feleslegben, és jodidion képződik, akkor az alábbi bruttó reakcióval állunk szemben:

$$
\mathrm{IO}_{3}^{-}+3 \mathrm{H}_{3} \mathrm{AsO}_{3}=\mathrm{I}^{-}+3 \mathrm{H}_{2} \mathrm{AsO}_{4}^{-}+3 \mathrm{H}^{+}
$$

Ezen sztöchiometriai arányok között az egyes bruttó reakciók lineáris kombinációja figyelhető meg.

A reakciómechanizmus összetett, ami általánosságban két részfolyamatra bontható fel. Első lépésként a jodátion a jodidionnal lép reakcióba, és köztitermékként jód képződik, mint ahogy az a (2.7) egyenletből is látható [57,58]

$$
\mathrm{IO}_{3}^{-}+5 \mathrm{I}^{-}+6 \mathrm{H}^{+}=3 \mathrm{I}_{2}+3 \mathrm{H}_{2} \mathrm{O}
$$

A második részfolyamatban az arzénessav a képződött jóddal reagál, és mindeközben arzénsav-molekulák és jodidionok képződnek. Az arzénessav gyengébb sav az arzénsavnál, ezért az utóbbi termékként egy hidrogéniont leadva egyszeresen negatív töltésú dihidrogén-arzenátionként lesz jelen a termékoldalon [59]

$$
\mathrm{H}_{3} \mathrm{AsO}_{3}+\mathrm{I}_{2}+\mathrm{H}_{2} \mathrm{O} \rightleftharpoons 2 \mathrm{I}^{-}+\mathrm{H}_{2} \mathrm{AsO}_{4}^{-}+3 \mathrm{H}^{+}
$$

Az első reakció a Dushman reakció, amelyre a sebességi egyenletet 1904-ben határozták meg

$$
-\frac{\mathrm{d}\left[\mathrm{IO}_{3}^{-}\right]}{\mathrm{dt}}=\left(\mathrm{k}_{1}+\mathrm{k}_{2}\left[\mathrm{I}^{-}\right]\right)\left[\mathrm{I}^{-}\right]\left[\mathrm{IO}_{3}^{-}\right]\left[\mathrm{H}^{+}\right]^{2}
$$

ahol $k_{1}=4,5 \cdot 10^{3} \mathrm{M}^{-3} \mathrm{~s}^{-1}$ és $k_{2}=1,0 \cdot 10^{8} \mathrm{M}^{-4} \mathrm{~s}^{-1}$ [60]. A második reakció már a Roebuck reakció, amelyre a sebességi egyenlet [61] a következő

$$
-\frac{\mathrm{d}\left[\mathrm{I}_{2}\right]}{\mathrm{dt}}=\mathrm{k}_{3}\left[\mathrm{I}_{2}\right]\left[\mathrm{H}_{3} \mathrm{AsO}_{3}\right] /\left(\left[\mathrm{I}^{-}\right]\left[\mathrm{H}^{+}\right]\right)
$$

ahol $k_{3}=3,2 \cdot 10^{-2} \mathrm{M}^{-1} \mathrm{~s}^{-1}$.

A mechanizmus során az elsô lépés a sebességmeghatározó, éppen ezért a bruttó folyamatban mind a jodidionok, mind pedig a hidrogénionok autokatalizátorként vesznek részt. A (2.9) sebességi egyenletből jól látható, hogy a diffúzív instabilitás elsô feltétele mind a hidrogénionra, mind pedig a jodidionra nézve teljesül. 
A reakció lejátszódását nagyban befolyásolja a kezdeti pH értéke, mert ettôl függ a front sebessége, vagyis hogy kellő mértékben és tanulmányozható időn belül képes a reakciófront végig terjedni a közegen, illetve ez befolyásolja a végső pH-t is [62]. A IAA reakció során fordított a sưrűségváltozás a $\mathrm{CT}$ reakcióhoz képest, vagyis a termékképződést sûrúségcsökkenés kíséri. Éppen ezért ebben az esetben a felfelé haladó frontok válnak instabillá, míg a lefele haladók megórzik sík alakjukat gravitációs erôtérben.

\subsection{A diffúziós együttható meghatározása NMR segítségé- vel}

Számos módszer létezik a diffúziós koefficiensek meghatározására, mint például a vezetôképesség mérésén alapuló eljárás, a Schlieren módszer, vagy a PFGSE-NMR-rel való mérés. E technikák közül az utolsót mutatom be ebben a fejezetben. A mágneses magrezonancia spektroszkópia rendkívül sokoldalú, hatékony, gyorsan fejlődo, és éppen ezért igen nélkülözhetetlen mérési technika a természettudomány, valamint az ipar számos területén. Napjainkban már nemcsak nagymúszeres szerkezetkutatási mérőmódszerként alkalmazzák, hanem a molekulák szerkezetének és dinamikájának tanulmányozására, biológiai folyamatok megismerésére, illetve az egészségügyben orvos-diagnosztikai céllal is. Az NMR-technika jelentőségének egyik nagy bizonyítéka az is, hogy ebben a témakörben számos Nobel-díjat is kiosztottak már az elmúlt 70 évben [63]. A kezdeti időszakában, ami 1945 és 1970 közé tehető, a folytonos pásztázás elvén alapuló módszereket (a gyenge, állandó amplitúdójú rádiófrekvenciás tereket) alkalmazták. Ma már leginkább a jóval fejlettebb impulzustechnikákkal dolgoznak, ahol rövid idejû, erôs rádiófrekvenciás impulzusokat használnak a gerjesztésre. Az alkalmazott mágnessel szemben támasztott követelmény a megfelelő erősség, a homogén és stabilis mágneses mezô. A szupravezető mágnesekkel elérhetô nagyobb mágneses tér a nagyobb érzékenység mellett, sokkal jobb spektrális felbontást is biztosít.

A PFGSE (pulsed field gradient spin echo) NMR módszert először 1983-ban használták a $\alpha$-ciklodextrin komplexek zárványainak jellemzésére [64]. Az egyik alkalmazási területe a HR-DOSY (high resolution diffusion ordered spectroscopy), ami második dimenzióként képes kezelni a diffúziót a 2D NMR spektrumban [65,66]. Általában így vizsgálják a természetben előforduló óriás szerves molekulák oldatbeli mozgását [67]. A DOSY egy precíz, matematikailag elhanyagolásmentes és kellő érzékenységú módszer a molekulák és a komplexek mérettől, alaktól és a közegtôl függő transzlációs diffúziós együtthatójának meghatározására, valamint oldatszerkezeti információk szerzésére is [68].

Ha egy feles spinú atommagot erôs, homogén mágneses indukciójú mezőbe $\left(\mathbf{B}_{\mathbf{0}}\right)$ helyezünk, akkor spinje a lehetséges kétféle orientáció egyikébe kerülhet [69,70], a z-tengellyel párhuzamosan. A két állapot betöltöttsége közti $\Delta E$ energiakülönbség a mag és a mágneses 
mező közti kölcsönhatás erősségétől függ. Termikus egyensúly esetén az egyes atommagoktól származó mágneses momentumok egy, a 2.6. ábrán bemutatott z-tengely körüli kúppalást mentén precesszálnak statisztikus eloszlás szerint. Ekkor $z$ irányú $\mathbf{M}_{\mathbf{0}}$ eredő mágnesezettség lép fel, ami a $\mathbf{B}_{0}$-val párhuzamos. Ez arányos az alap és a gerjesztett állapotok populációjának különbségével.

A termikus egyensúlyban minden magspin a saját Larmor-frekvenciájával $\left(\omega_{0}\right)$ precesszál a z-tengely körül. Ekkor a mintára monokromatikus rádiófrekvenciás (RF) sugárforrásból egy rövid, intenzív $\mathbf{B}_{1}$ mágneses indukciójú impulzust kibocsátva $\left(\omega_{1}=\omega_{0}\right)$ a megfelelő hosszúságú impulzus az $\mathbf{M}_{\mathbf{0}}$-át az xy-síkba forgatja. Ennek hatására fáziskoherencia alakul ki a momentumok között, mivel nem lesz véletlenszerú a magok mágneses momentumának eloszlása az $x y$-síkban. Az idő előrehaladtával ezen összhang felborul, és így a mágnesezettség vektor exponenciálisan csökkenni kezd, miközben az $x$-tengelyben elhelyezett tekercsben egyre gyengébb jelet indukál. A detektálható periodikusan csillapodó jel a szabad indukciós jel, vagyis a FID (free induction decay) [71]. Valójában ez sok oszcilláló hullám összege, amelyet Fourier-transzformációval analizálhatunk. Ennek eredményeképpen az intenzitások időbeli eloszlását intenzitás-energia spektrummá alakíthatjuk át, ami az NMR spektrumot jelenti.

Az egyes molekulák mozgásának detektálása érdekében a $\mathbf{B}_{\mathbf{0}}$ sztatikus mágneses térrel párhuzamosan létre kell hoznunk egy lineáris gradiensteret, amely által a spinek precesszálásának frekvenciája a z-koordináta függvénye lesz. A molekulák diffúziója miatt azonban fáziseltolódás fog kialakulni az idő előrehaladtával, és ez megjelenik a jel csillapodásában. A jeldetektálás javítása érdekében a BPP-LED (bipolar pulse pair longitudinal eddy current delay) szekvenciát szokták alkalmazni, mikor is csak a RF impulzus után adják a gradienst négyszögimpulzusban a rendszerre az echó szekvencia két szakaszában, miközben csökken-

(a)

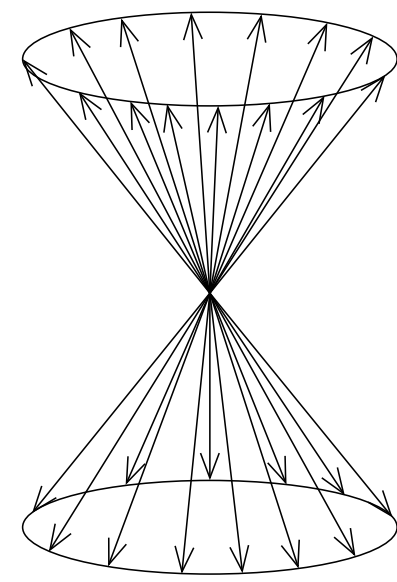

(b)

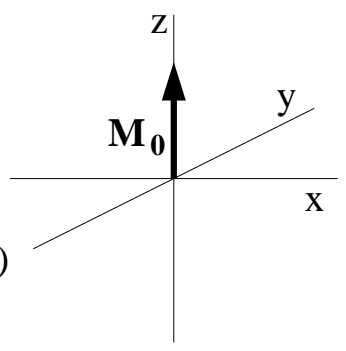

2.6. ábra. Termikus egyensúlyban lévő atommagok halmazának vektormodellje (a). Az $\mathbf{M}_{\mathbf{0}}$ eredő mágnesezettség, ami z-tengely irányába mutat (b) [69]. 
nek az örvényáramok (lásd a 2.7. ábrát).

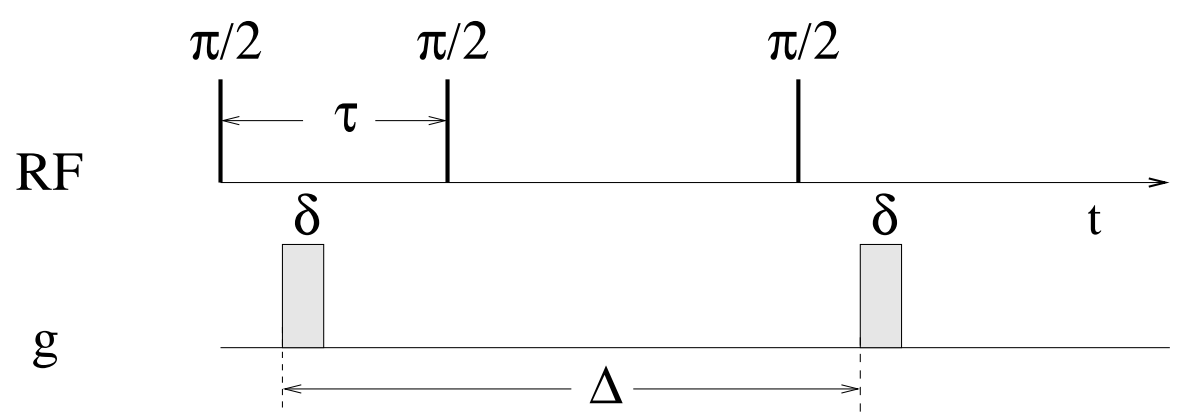

2.7. ábra. Az alkalmazott BPP-LED impulzusszekvencia sematikus rajza.

A jelcsillapodás így a módosított Stejskal-Tanner egyenlettel [72] adható meg:

$$
I(g)=I(0) \exp \left[-\gamma^{2} g^{2} \delta^{2} D\left(\Delta-\frac{\delta}{3}-\frac{\tau}{2}\right)\right]
$$

ahol $I(g)$ a jel intenzitása, $I(0)$ a gradienstér nélküli jelintenzitás, $\gamma$ a hidrogénatom giromágneses hányadosa, $\Delta$ a gradiensimpulzusok kezdete között eltelt idő, $\delta$ a gradiensimpulzus időtartama, $g$ a gradiens-térerősség, $\tau / 2$ a két ellentétes polaritású és $180^{\circ}$-os RF impulzussal elválasztott gradiensimpulzus közötti időeltolódás, $D$ pedig a diffúziós koefficiens. Ezen egyenlet segítségével számolhatók ki a diffúziós együtthatók exponenciális lefutású görbék illesztésével.

A kétdimenziós impulzusszekvencia a gradiens-térerő növekvő értékeinél az idő függvényében rögzített FID-ek sorozatát eredményezte, azaz a mi esetünkben a második dimenziót a növekvő gradienstér képezte, és így a diffúzió könnyen tanulmányozható volt. 


\section{3. fejezet}

\section{Célkitúzés}

Frontszerúen terjedô kémiai reakciókban létrejövô mintázatképzôdéseket vizsgáltam a doktori munkám során. Az elsố célom a diffúzív instabilitás kimutatása volt a jodát-arzénessav reakcióban a hidrogénionok megkötésével. A különböző tér- és idôbeli alakzatok regisztrálása és mennyiségi jellemzése mellett, bizonyos esetekben megmértem magában a reakcióösszetételnek megfeleló közegben a kinetikai szempontból számunkra fontos komponensek diffúziós együtthatóját. Ehhez az in situ módon is alkalmazható pulzusgradiens spin echó NMR módszert használtam, hiszen már korábban is sikeresen alkalmaztuk ilyen jellegú mérésekre $[73,74]$. Előnye, hogy nem igényel koncentrációgradienst, kevés minta szükséges a méréshez és kellő mértékben pontos.

Rongy és munkatársai elméleti számítások során azt jósolták, hogy a vízszintesen terjedó frontok mennyiségi jellemzóje - ami nem más, mint a keveredési hossz - a reakcióedény magasságának második hatványával arányos [75]. A korábbi kísérletek arra engedtek következtetni, hogy ez az arányosság nem pontosan így áll fenn, ezért célul túztem ki a skálázási törvény kísérleti meghatározását is a jodát-arzénessav reakcióban olyan kémiai összetétel mellett, ahol a jodátiont nem redukáltuk teljesen jodidionná.

Továbbá megnéztem azt is, hogy a klorit-tetrationát autokatalitikus reakcióban történő makroszkopikus önszervezôdésre milyen hatással van a harmadik dimenzió kiszélesítése. Ez azért volt fontos, mert korábban a csoportunkban polielektrolit hozzáadásával oszcilláló mintázatot tudtak kimutatni [76]. A jelenség kialakulásának oka még nem egyértelmú, ezért polielektrolit nélküli rendszerekben, szélesebb edényekben kívántuk tanulmányozni az általunk vizsgált reakciókat.

A kutatócsoportunkban eddig igen behatóan tanulmányozták már a migrációt, a diffúziót, valamint a súrúség- és a viszkozitásváltozás következményeképpen fellépő konvekciót [55,77-79]. Éppen ezért a munkám befejező részében a Marangoni instabilitás hatására kialakuló közegmozgást tanulmányoztam, ami a felületi feszültségváltozás eredményeképpen alakul ki. 
Feladatom volt megkeresni a megfelelő modellreakciókat, kidolgozni a jól alkalmazható recepteket, finomítani az alkalmazott programokat a precíz kiértékelés érdekében. A konvekciómentes felületi feszültségváltozás vizsgálata céljából megalkottam a kísérletekhez szükséges cellákat, amelyek majd alkalmasak lesznek a mikrogravitációs kísérletek végrehajtásához is. 


\section{4. fejezet}

\section{Kísérleti rész}

\subsection{Oldat- és gélkészítés}

A diffúzív frontinstabilitást csak a jodát-arzénessav rendszerben vizsgáltam meg, míg a közegmozgás mintázatképződésre gyakorolt hatását két rendszerben (IAA, CT) is tanulmányoztam. A reaktánsoldatok elkészítéséhez minden esetben a következô analitikai tisztaságú vegyszereket és kétszer ioncserélt vizet használtam: nátrium-metaarzenitet (Reanal), arzén-trioxidot (Reanal), kálium-jodátot (Reanal), poli(akrilsavat) (Aldrich, $M_{r}=10^{5} ; 35$ tömegszázalékos oldat), sztearinsavat (Reanal), nátrium-hidroxidot (Spektrum 3D), káliumtetrationátot (REANAL), 80 \%-os tisztaságú nátrium-kloritot (Aldrich), nátrium-szulfit-7hidrátot (Reanal), poli(vinilalkoholt) (Fluka, $\left.M_{r}=9000-10000\right)$. Indikátorként először kongóvöröst - ami igen karcinogén hatású -, majd később brómfenolkéket alkalmaztam, hogy a megfelelő színváltozást figyelemmel kísérve a reakció követhetô legyen.

A IAA reakcióban fontos a kiindulási $\mathrm{pH}$ értéke, mivel ez jelentősen befolyásolja a reakciósebességet [62]. Kezdetben a pH-t 8-ra állítottam 1 M koncentrációjú kénsavoldat (Spektrum 3D) segítségével Orion 420 típusú pH-mérôt alkalmazva, majd 7-re a front könnyebb iniciálása végett. Ezen a pH-n a reakciófront sebessége közel független a kiindulási pH-tól, továbbá itt még szabad az autokatalizátor kötôhelyeinek a többsége. Abban az esetben, amikor az autokatalizátor megkötése volt a cél, vagy poliakrilamid-oldat (PAA) és nátrium-polimetakrilát-oldat (PMA) 3:1 molarányú kopolimerét használtam, vagy pedig nátrium-metakrilát tartalmú poliakrilamid-gélt alkalmaztam. Mindkét módszernél a polimerláncban lévő immobilis karboxilátcsoportok segítségével csökkenthető le a hidrogénion diffúziója. Végezetül egy polielektrolitot, a poli(akrilsav) nátrium sóját is kipróbáltam, ami szintén karboxilátcsoportokat tartalmazott. A kísérletek reprezentálhatósága érdekében ebből háromnaponta friss oldatot készítettem.

A térhálós poliakrilamid polimert különböző összetételekben készítettem el, hogy megnézzem, adott megkötésnél, milyen szerkezetek alakulnak ki. Térhálósítás céljából N,N’- 
metilén-bisz-akrilamidot használtam, ugyanis ez képes hidakat képezni a gyökös polimerizációval létrehozott hosszú polimerláncok között. Az aktivátor trietanolamin-oldat, az iniciátor pedig kálium-peroxo-diszulfát volt. A tömbbe beépített nátrium-metakrilát a karboxilátcsoportok forrásaként szolgált. Az egyes anyagok mennyiségét úgy változtattam, hogy a kettős kötések száma a különböző gélekben azonos legyen. Az alkotók pontos mennyiségét a 4.1. táblázat foglalja össze.

4.1. táblázat. A különböző megkötésú gélek összetétele. A BA az N,N'-metilén-biszakrilamidot, az AM az akrilamidot, a TEA a $30 \mathrm{v} / \mathrm{v} \%$-os trietanolamin-oldatot, a $\mathrm{NaM}$ a 0,15 M koncentrációjú nátrium-metakrilát-oldatot, a KPDS a 0,11 M koncentrációjú káliumperoxo-diszulfát-oldatot jelöli [78].

\begin{tabular}{||l||c|c|c|c|c|c|c||}
\hline \hline Megkötés & $0 \%$ & $20 \%$ & $40 \%$ & $50 \%$ & $60 \%$ & $70 \%$ & $80 \%$ \\
\hline \hline $\mathrm{V}_{\text {víz }} / \mathrm{cm}^{3}$ & 13,7 & 13,1 & 12,5 & 12,2 & 11,9 & 11,6 & 11,3 \\
\hline $\mathrm{m}_{\mathrm{BA}} / \mathrm{g}$ & 0,2 & 0,2 & 0,2 & 0,2 & 0,2 & 0,2 & 0,2 \\
\hline $\mathrm{m}_{\mathrm{AM}} / \mathrm{g}$ & 3,000 & 2,994 & 2,987 & 2,984 & 2,980 & 2,978 & 2,974 \\
\hline $\mathrm{V}_{\mathrm{TEA}} / \mathrm{cm}^{3}$ & 0,3 & 0,3 & 0,3 & 0,3 & 0,3 & 0,3 & 0,3 \\
\hline $\mathrm{V}_{\mathrm{NaM}} / \mathrm{cm}^{3}$ & 0,0 & 0,6 & 1,2 & 1,5 & 1,8 & 2,1 & 2,4 \\
\hline $\mathrm{V}_{\mathrm{KPDS}} / \mathrm{cm}^{3}$ & 1 & 1 & 1 & 1 & 1 & 1 & 1 \\
\hline \hline
\end{tabular}

A gél készítése során minden esetben először feloldottam az N,N'-metilén-bisz-akrilamidot (Reanal) forró desztillált vízben, majd lehûtöttem szobahőmérsékletűre. Ezek után hozzáadtam az akrilamidot (Spektrum 3D), a 30 v/v\%-os trietanolamin-oldatot (Reanal) és a 0,15 M koncentrációjú nátrium-metakrilát-oldatot (Aldrich) kevertetés, illetve $\sim 5^{\circ} \mathrm{C}$-ra történő hû́tés mellett, hogy a polimerizáció ne induljon be idő előtt. A vízsugárszivattyúval történő gázmentesítés - az oldott oxigén eltávolítása céljából - és a kálium-peroxo-diszulfát (Reanal) iniciátor hútött oldathoz való hozzáadása után, az egész elegyet előre egymáshoz rögzített plexi lapok közé fecskendeztem, s a polimerizáció végéig állni hagytam. Az így előállított $1 \mathrm{~mm}$ vastagságú gélt desztillált vízben áztattam 24 órán keresztül, miközben többször is vízcserét hajtottam végre, hogy a polimerizáció után visszamaradó, monomer akrilamid molekulák jelentős részét eltávolítsam.

A CT kísérletek végrehajtása során mindvégig a $\left[\mathrm{NaClO}_{2}\right]_{0} /\left[\mathrm{K}_{2} \mathrm{~S}_{4} \mathrm{O}_{6}\right]_{0}=4$ koncentrációaránynál dolgoztam. A reaktánsoldathoz nátrium-hidroxid-oldatot adtam a reakció eltarthatósága érdekében. Az egyes kísérletek esetében alkalmazott reaktánselegyek összetételét az Eredmények fejezetben tüntetem fel, mivel nagyban függtek a vizsgálni kívánt jelenségtől. 


\subsection{A kísérleti elrendezések}

Kísérleteimet többféle elrendezésben hajtottam végre, attól függően, hogy melyik instabilitást kívántam tanulmányozni. A kis viszkozitású polielektrolitokkal végzett kísérleteknél, a kétdimenziós mintázatok könnyebb megfigyelésének érdekében [80], egy kezdeti viselkedés vizsgálatára alkalmas kis Hele-Shaw reakcióedényt használtam. Ez két egymáshoz közeli párhuzamos plexi lapból állt, és közéjük különböző vastagságú távtartót helyeztem el a vizsgálat céljától függően, ahogy az a 4.1. ábrán is látszik. A folyadékveszteség elkerülése miatt a plexi lapok és a távtartó közé vékony vazelin réteget vittem fel. A cellát igyekeztem buborékmentesen feltölteni a reaktánsoldattal, mert különben a képzôdött gázbuborékok könnyedén befolyásolhatták a kialakuló mintázatot, valamint nagymértékben megnehezítették a mennyiségi kiértékelést is. A megfelelő sík front indításához egy Power supply 18135/18142 típusú tápegységet alkalmaztam. Ezt a reakcióedényhez rögzített két, egymással párhuzamos, 0,25 mm átmérőjú, sík platinaelektródhoz csatlakoztattam. Az anódon hidrogéniont termelő, 3 V feszültségú, 15 - 40 másodperc idejű elektrolízissel indítottam el a savkatalizált reakciókat. Számítógép segítségével 0,6 - 5 másodperces idôközönként képeket rögzítettem a mintázatról. Attól függően, hogy a reakciófrontok viselkedését milyen módon szerettem volna tanulmányozni, az edényeket különböző térállásokban helyeztem el (függőlegesen lefelé, felfelé, továbbá vízszintesen).

Amikor csak a diffúzió okozta mintázatképződés vizsgálata volt a célom, akkor a gélből $6 \mathrm{~cm} \times 7,5 \mathrm{~cm}$ nagyságú, téglalap alakú darabokat vágtam ki, és ezt áztattam 30 percen keresztül $200 \mathrm{~cm}^{3}$ térfogatú reaktánsoldatban, miközben keveréssel biztosítottam a homogén eloszlást. Mindezek után az aktív gél mindkét felérôl szúrőpapírral leitattam a felesleges

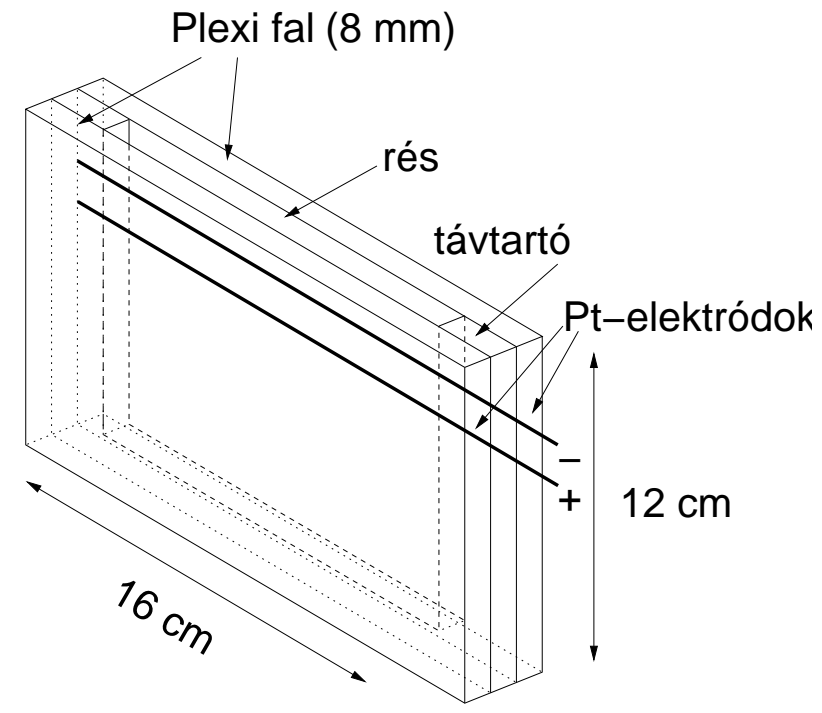

4.1. ábra. A kis Hele-Shaw reakcióedény sematikus rajza. 


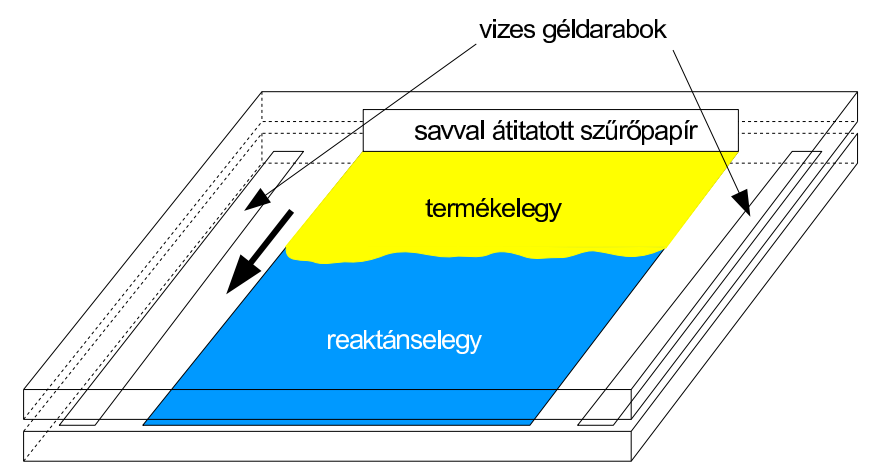

4.2. ábra. Az alkalmazott reaktor vázlatos rajza. A nyíl a front haladási irányát mutatja.

oldatot, majd amint azt a 4.2. ábra mutatja ezt is két plexi lap közé tettem. A vizsgált gél két oldalára egy-egy vizes maradék géldarabot helyeztem el, hogy ezzel megakadályozzam a gél széleinél bekövetkező gyorsabb fronthaladást. Az egész reaktor ragasztószalaggal való körbe tekerése biztosította a reaktánsoldat gélbeni koncentrációjának állandóságát [78]. A reakciót egy kénsavba áztatott szúrőpapírral iniciáltam, mivel a platinaelektródokkal történő elektrolízis nem bizonyult megfelelő megoldásnak. A hidrogénion nagymértékú megkötése miatt hosszabb elektrolízisre volt szükséges, de ekkor nem lehetett sík alakú frontot indítani. A vastagabb platinaszál alkalmazása pedig azért nem volt jó, mert elvágta az $1 \mathrm{~mm}$ vastag géldarabot. Ekkor a 4.3. ábrán bemutatott elrendezést alkalmaztam a kísérletek nyomon követésére.

A függőlegesen kialakuló frontok hosszútávú viselkedésének tanulmányozására egy hoszszabb Hele-Shaw edényt használtam, amit függőlegesen helyeztem el az optikai padon. A kamera és a reakcióedény közti távolság tetszés szerint volt állítható, attól függően, hogy

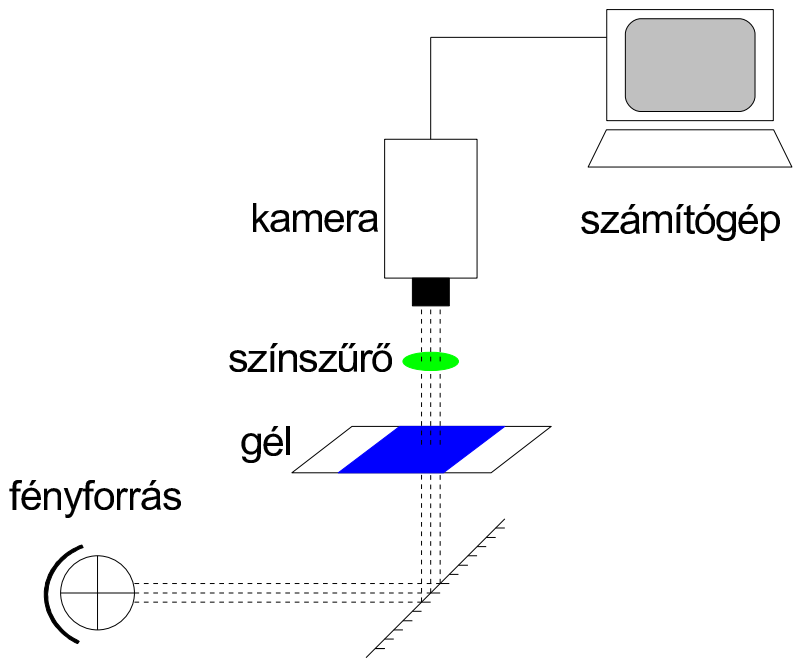

4.3. ábra. A kísérleti elrendezés. 
mennyire nyúlt meg az időben állandó mintázat a vízszintesen haladó stabil reakciófrontoknál. A 4.4. (a) ábrán egy ilyen cella elölnézeti képe látható. A beépített $1 \mathrm{~cm}$ magas és $1 \mathrm{~mm}$ széles falak az edény könnyebb feltölthetőségét segítették a Marangoni instabilitás megnyilvánulásának vizsgálatakor, aminek az oldalnézeti képét a 4.4. (b) ábra szemlélteti. Az edény magasságát 1 és $4 \mathrm{~cm}$ között, vastagságát pedig 3 és $10 \mathrm{~mm}$ között változtattam, miközben az oldatréteg magassága mindegyik kísérlet esetében $1 \mathrm{~cm}$ volt. A folyadékrétegek felett 1 , 2 és $3 \mathrm{~cm}$ magas légréteget biztosítottam, hiszen ekkor nyílt lehetôség az instabilitás kialakulására. Csak a sûrúségkülönbség miatt kialakuló mintázatot is megvizsgáltam $1 \mathrm{~cm}$ magas edényben, ahol nem volt légréteg a reakciótér felett, és ekkor a Marangoni instabilitás sem tudott fellépni (lásd oldalnézetből a 4.4. (c) ábrán).

(a)

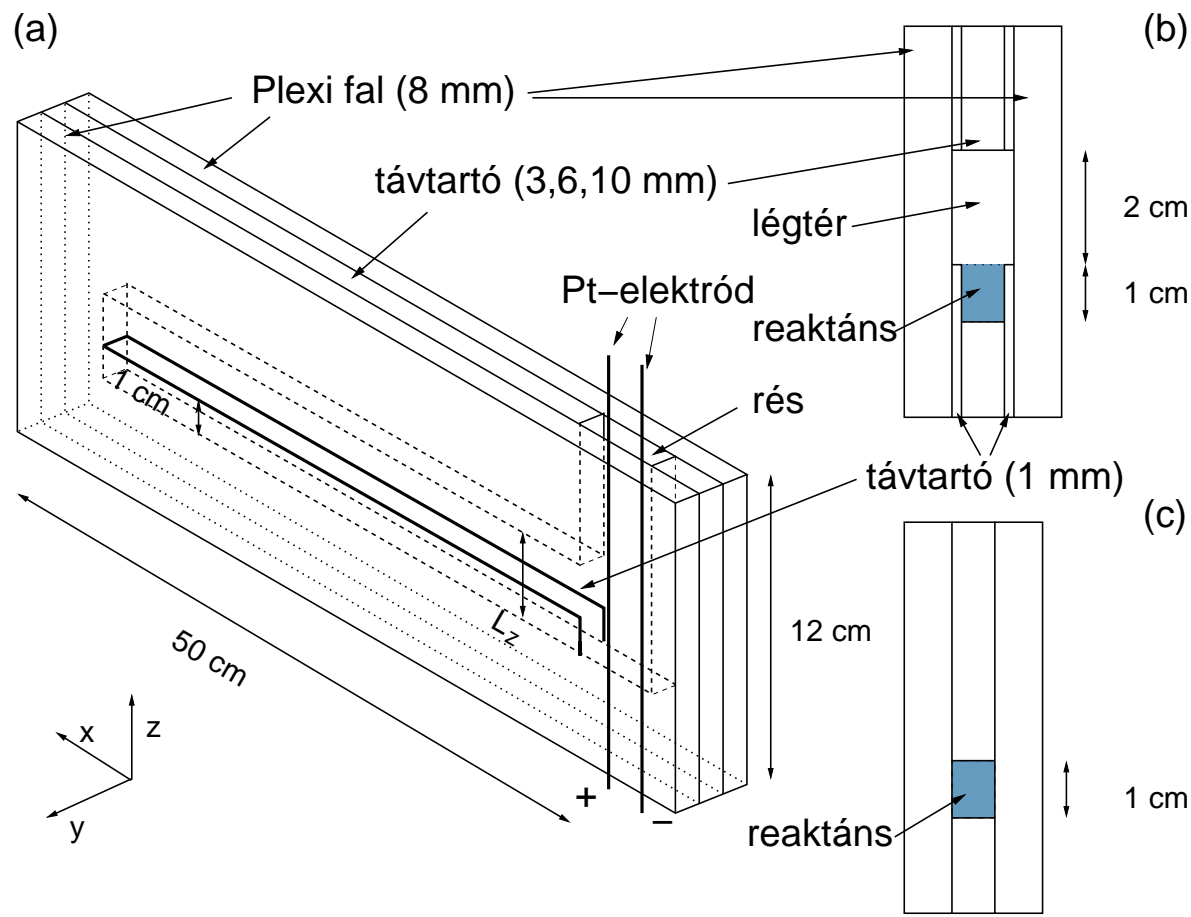

4.4. ábra. A frontok hosszútávú viselkedésének tanulmányozásához használt Hele-Shaw edény sematikus rajza elölnézetből (a), légréteg esetén oldalnézetből (b), valamint szabad felszín nélkül oldalnézetból (c).

Ugyanezt a cellát és elrendezést alkalmaztam a skálázási törvény meghatározásához is, csak akkor a plusz $1 \mathrm{~cm}$ magas falakat nem építettem be a rendszerbe, illetve változtattam az oldatréteg magasságát. Ahol a hőeffektus jelentős volt, ott a reakcióteret termosztálni kellett ahhoz, hogy reprodukálható kísérletek születhessenek. A hômérséklet beállításához az edényre plexiből készült hûtőköpenyeket helyeztem fel, amelyekben hûthetô-füthető termosztáttal (Heto HMT 200) megfelelő hőmérsékletưre hûtött víz-etilénglikol elegy keringett. A hútôköpenyt előre feltettem a cellára, és még a reaktánsoldatok betöltése után is vártam öt percet a reakció indítása elôtt, hogy beálljon a termikus egyensúly a hútőközeg és 
a reaktánselegy között.

Ahhoz, hogy meg tudjam vizsgálni, hogy a makroszkopikus önszerveződésre milyen hatással van a harmadik dimenzió kiszélesítése, egy teljesen új cellát kellett tervezni. Először egy $12 \mathrm{~cm} \times 20 \mathrm{~cm}$ alapterületû edényben térképeztem fel a kialakuló mintázatokat, amelynek a magassága $1-10 \mathrm{~cm}$-ig volt variálható, és így igen érdekes cellás szerkezetek alakultak ki. Annak érdekében, hogy ezeket a mintákat oldalról és felülről is egyszerre tanulmányozni tudjuk, egy újabb, már végleges cella került kialakításra üvegből, pusztán praktikus okokból kiindulva. A 4.5. ábrán látható üvegküvetta szélességét a kísérletek során 6 és $11 \mathrm{~mm}$ között változtattam. Az figyelhetô meg oldalnézetből a 4.6. ábrán, hogy hogyan

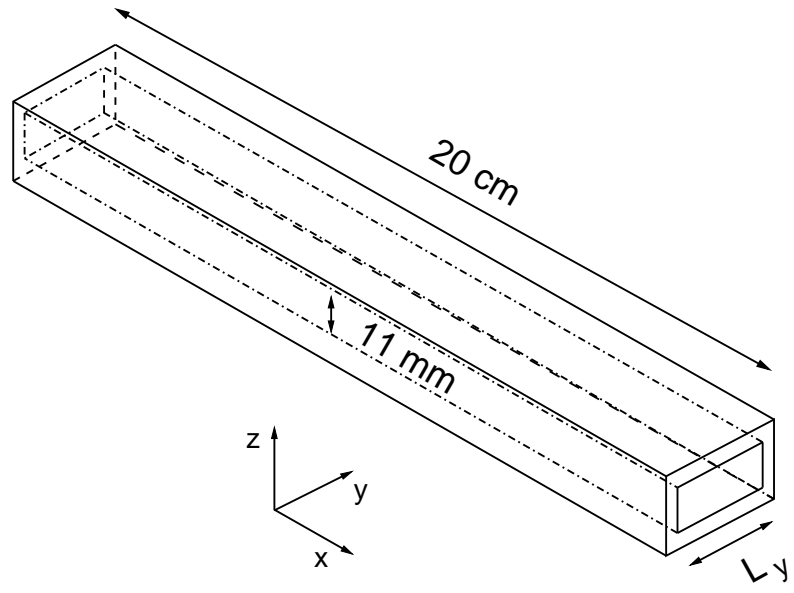

4.5. ábra. A háromdimenziós szerkezetek vizsgálatára alkalmas cella.

lehetett megvalósítani az oldalnézeti és a felülnézeti kép egyszerre történő rögzítését. Ehhez két tükör volt a segítségemre, amelyeket 45 fokos szögben helyeztem el a cellához képest. Az üvegcsövek végét ragasztószalaggal körbetekertem, hogy az oldat ne folyjon el. A front indításához szükséges hidrogéniont termelő elektrolízishez szintén platinadrótokra kapcsolt feszültségkülönbséget alkalmaztam.

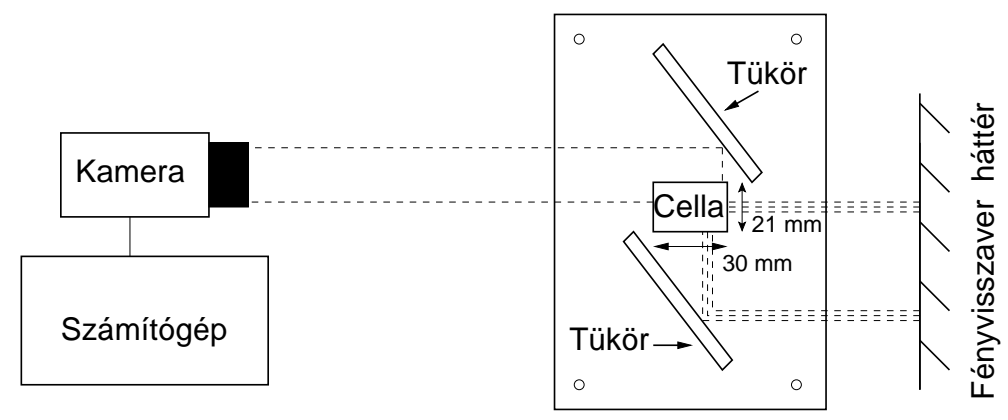

4.6. ábra. A háromdimenziós szerkezetek vizsgálatára alkalmas kísérleti elrendezés. 


\subsection{Az alkalmazott kísérleti mérômódszerek}

A reakciók végbemenetelekor fellépő hőeffektust egy zománcozott J-típusú Fe-CuNi termoelem segítségével követtem nyomon. Minden esetben a reaktánseleggyel feltöltött reakciótérbe helyeztem el a mérôfejet egy 0,5 mm átmérôjú furaton keresztül úgy, hogy az szemben legyen a front haladásának irányával, a 4.7. ábrán látható módon. A referenciaszálat egy Dewar-edénybe lógattam, ami szobahőmérsékletú ioncserélt vizet tartalmazott. A reakció elindítása után a termelődő hő elektromos jelet indukált a vezetődrótban. A termoelemet egy digitális mérőmúszerhez csatlakoztattam (Thermometer: AT-I 071206), és ennek az alkalmazásával egy számítógépre rögzítettem a feszültség-idő párokat. A múszert csapvíz segítségével kalibráltuk be, majd a mért feszültségértékekből a kalibrációs görbe alapján határoztam meg a maximális hőmérséklet-emelkedést $(\Delta T)$ az egyes reakciókban. Mivel híg oldatokkal dolgoztam, a folyamatot kísérô hômérséklet-változás okozta sưrüségváltozást $\left(\Delta \rho_{T}\right)$ a víz hőtágulása alapján a következőképpen határoztam meg:

$$
\Delta \rho_{T}=-2,31 \cdot 10^{-4} \frac{\mathrm{g}}{\mathrm{cm}^{3} \mathrm{~K}} \cdot \Delta \mathrm{T} .
$$

A kémiai összetétel változásából adódó sûrúségkülönbséget $\left(\Delta \rho_{C}\right)$ a reaktánsok és a termékek súrúségéből kaptam meg, amelyeket egy Anton Paar DMA 58, illetve 500 típusú digitális sûrúségmérô készülék segítségével mértem meg. A méréseket 4 és $25^{\circ} \mathrm{C}$-on végeztem el $10^{-5}$, valamint $10^{-4} \mathrm{~g} \mathrm{~cm}^{-3}$ pontossággal.

A felületi feszültségek meghatározásához Kruss easyDyne mérőmúszert használtam. A mérések egyik része a tanszékünkön, míg másik része a toulouse-i Paul Sabatier Egyetemen került kivitelezésre. A felületi feszültség $(\gamma)$ nem más, mint a felület egységnyi hosszú vonalán a felületre merôlegesen ható összehúzóerô. Értéke függ a hômérséklettől, a határoló

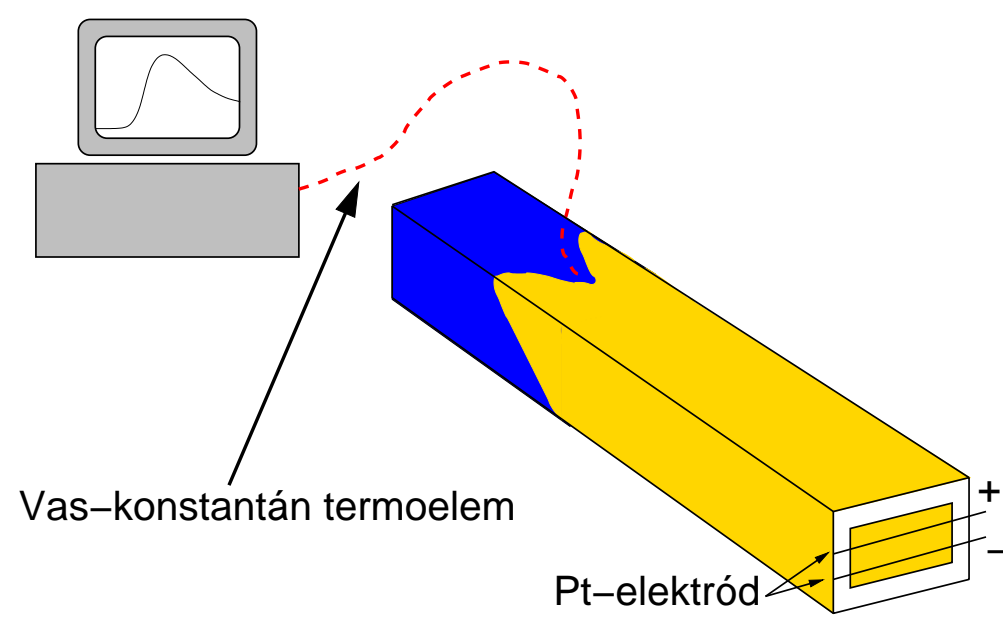

4.7. ábra. A reakciót kísérô hőeffektus mérésének sematikus rajza. 
közegtől és az anyagi minőségtől, viszont független a felület alakjától és nagyságától. Számos mérési módszer alkalmazható a meghatározásához, mint például a kapilláris emelkedés módszere, a nyugvó csepp, a sztalagmométeres, a buboréknyomásos, valamint a kiszakításos módszer, amit Du Noüy-gyưrú vagy Wilhelmy-lemez segítségével lehet végrehajtani. A dinamikus platina Wilhemy-lemezt alkalmazó technikával dolgoztam. A módszer lényege az, hogy a folyadékba részlegesen belemerülő lemezre ható erôt mérjük $(F)$. A gravitációs erő és a felületi feszültség lefelé húzza a lemezt, míg ezekkel ellentétesen a rugó és a folyadék felhajtóereje hat. Az eredő $F$ erőből kiszámítható a $\gamma$ a következő egyenlet alapján:

$$
\gamma=\frac{F}{2 l \cos \theta}
$$

ahol az $l$ a belemerülés mélységét, a $\theta$ pedig a nedvesedés szögét jelöli. Tökéletes nedvesítésnél $\cos \theta=1$.

Az NMR méréseket egy Bruker Avance DRX 500-as spektrométerrel végeztem el $450 \mu \mathrm{l}$ nyi mintát tartalmazó, $5 \mathrm{~mm}$ átmérōjú NMR csövek (Spektrum 3D) segítségével. A mérés csak 30 perccel azután kezdődhetett, hogy a minta a mágneses térbe került, mert ennyi idôre volt szükség a hőmérséklet stabilizálódásához. Ez alatt lehetôség nyílt a mérési paraméterek beállítására. Egymás után három mérésre volt szükséges ahhoz, hogy a számunkra megfelelő minőségú NMR spektrumhoz jussunk. Az elsô mérés a vízjel helyének, vagyis a kémiai eltolódásának a pontos meghatározása miatt volt fontos. Ehhez nélkülözhetetlen volt a megfelelő paraméterállomány, a vevőkör érzékenységének, valamint a mágneses tér homogenitásának a beállítása és idóbeli változásának kompenzálása. Mindezek után kezdődhetett a mérés. A kész spektrum helyben való feldolgozása a zaj kivágását, a Fourier-transzformációt és a fázisolást jelentette. Az így elóállított spektrumból a víz jelének a helyét kaptam meg, amire a vízelnyomással történő méréshez volt szükség. Ez a WATERGATE módszer [81] a vizsgált anyagok jelének zajszintből való kinyerését segíti, az oldószer domináns jelének az elnyomásával. Ezek után a mérést folytatva beállítottam a spektrum közepét a víz jeléhez, majd jöhetett a DOSY futtatása, ami a pulzusgradiens spin echó NMR módszer alkalmazását jelentette. Az így elkészült kétdimenziós spektrumot értékeltem ki, és számoltam belóle a megfelelő diffúziós koefficienseket a spektrumanalízis alfejezetben leírtak alapján.

A mérések során a reakcióközegeknek megfelelő koncentrációkkal és ionerôsségekkel dolgoztam. A klorit-tetrationát reakcióban nátrium-poliakrilát különböző mennyiségben való alkalmazásakor különféle szerkezetek alakultak ki, és ezek magyarázatának az alátámasztására meghatároztam a rendszerben jelen lévő néhány komponens diffúziós koefficiensét. A mérés során használt összetételeket a 4.2. táblázatban összegeztem. Az egyes alkotóelemek diffúziójának megmérése után azt tapasztaltam, hogy jelentéktelen mértékben térnek el egymástól a savas, illetve a lúgos közegben mért diffúziós együtthatók [11]. Éppen ezért, ezek 
4.2. táblázat. A klorit-tetrationát rendszer NMR méréséhez használt savas, illetve lúgos elegyek összetétele. A NaAc a nátrium-acetátot, a BFK a brómfenolkéket, a Na-PA a nátriumpoliakrilát-oldatot jelöli.

\begin{tabular}{||c|c|c|c|c|c||}
\hline \hline$[\mathrm{NaAc}] /$ & {$\left[\mathrm{Na}_{2} \mathrm{SO}_{4}\right] /$} & {$[\mathrm{HCl}] /$} & {$[\mathrm{NaOH}] /$} & {$[\mathrm{BFK}] /$} & {$[\mathrm{Na}-\mathrm{PA}] /$} \\
\hline \multicolumn{6}{c||}{$\mathrm{mM}$} \\
\hline \hline 20,00 & 5,00 & 0,01 & 0,01 & 0,16 & 25,00 \\
\hline \hline
\end{tabular}

után már csak mindig a reaktánselegy esetében mértem meg a diffúziós koefficienseket. Értelemszerúen mikor a savas kémhatású oldatot készítettem, akkor az oldat pH-ját sósavval, mikor a lúgosat, akkor pedig nátrium-hidroxid-oldattal állítottam be a megfelelő értékre. Ez alapján értelmezendôek a 4.2. táblázatban feltuintetett adatok. A mintákhoz az össztérfogat 10 v/v\%-ában nehézvizet (Aldrich) adtam.

A IAA rendszer esetében a mérések során négy mintát vizsgáltam meg: az első minta a reaktánsoldatnak megfelelő vizes oldat, a második minta a nátrium-poliakrilátot tartalmazó szintén vizes oldat, míg a harmadik és a negyedik minta a reaktánsoldattal átitatott 0,075 g, illetve 2 g mennyiségú N,N'-metilén-bisz-akrilamidot tartalmazó gél volt. A káliumjodát-oldatot 0,3 M koncentrációjú nátrium-acetát-oldattal (Reanal) helyettesítettem, hogy az autokatalitikus reakció ne játszódhasson le, valamint hogy az oldat NMR aktívvá váljon. A pontos koncentrációk a 4.3. táblázatban találhatóak.

4.3. táblázat. A jodát-arzénessav reakció NMR méréséhez használt reaktánselegyek összetétele. A NaAc a nátrium-acetátot, a BFK a brómfenolkéket, a Na-PA a nátrium-poliakrilátot, a NaM a nátrium-metakrilát gélbeni koncentrációját jelöli.

\begin{tabular}{||c|c|c|c|c||}
\hline \hline$[\mathrm{NaAc}] /$ & {$\left[\mathrm{H}_{3} \mathrm{AsO}_{3}\right] /$} & {$[\mathrm{BFK}] /$} & {$[\mathrm{Na}-\mathrm{PA}] /$} & {$[\mathrm{NaM}] /$} \\
\hline \multicolumn{5}{|c||}{$\mathrm{mM}$} \\
\hline \hline 12,90 & 49,90 & 0,16 & 31,20 & 20,00 \\
\hline \hline
\end{tabular}




\section{5. fejezet}

\section{Kiértékelési módszerek}

\subsection{A frontprofil és a frontsebesség meghatározása}

A különböző cella elrendezéseknél a front tér- és időbeli változásának a követésére egy fekete-fehér CCD (Panasonic WV-BP330/B), illetve egy színes kamerát (Sony DFW-x710) használtam, ami egy képfeldolgozó rendszerrel volt összekötve. Az optikai padon rögzített, reaktánseleggyel feltöltött reaktort (cellát, csövet) egy írásvetítő matt felületrôl visszaverôdő fényével világítottam meg. A kiértékelhetőség javításának érdekében a legtöbb esetben egy színszúrőt is elhelyeztem a reaktor és a kamera közti fényútba. A kamera a front haladási sebességének megfelelően megadott időközönként, $800 \times 600$ képpontból álló jeleket rögzített, amelyeket egy MVdelta (Mátrix Vision) képfeldolgozó kártya segítségével digitalizáltam a CCD kamera esetében. Ezzel a front helyzetét és a képződött mintázat alakját tudtam megadni. A kiértékelés során a különböző fényintenzitásokhoz szürkeségi skálát rendelt az alkalmazott képfeldolgozó program. A kapott felvételek 256 árnyalatból álltak, ahol a 0 a feketének felelt meg, és ahogy a szín egyre világosabb árnyalatúvá vált, úgy jutott el a fehérhez, ami pedig a 255-ös volt. A kongóvörös indikátor esetében a front előtti magasabb pH-jú, világosabb (piros), így nagyobb fényintenzitású reaktánst a nagyobb szürkeségi érték jelölte, míg a front utáni több hidrogéniont tartalmazó, sötétebb (kék), kisebb intenzitású termékhez az alacsonyabb szürkeségi érték tartozott. A brómfenolkék indikátornál ez pont fordított, mivel ott a reaktánsoldat kék színú volt, míg a termékelegy pedig sárga. A kongóvörös indikátornál alkalmazott színszưrő transzmittanciája $548 \mathrm{~nm}$ volt, míg ez a brómfenolkék esetében $468 \mathrm{~nm}$.

A frontalakok idôbeli előrehaladásának tanulmányozásakor a kapott szürkeségi értékek változását kell vizsgálni. A képeknél minden egyes oszlopban a front terjedésével párhuzamosan az adott pontokhoz tartozó szürkeségi értékek hely szerinti deriváltjának megfelelő szélsőértéke megadja az adott időpillanathoz tartozó front helyzetét. Ez lehetôvé teszi a front számítógépen való nyomon követését, illetve elemzését. A front haladási irányára 
merőlegesen minden oszlopban meghatározva a létrejövő front helyzetét megkaphatjuk az adott időhöz tartozó frontprofilt, vagyis leképezhetjük a mintázat időbeli változását, amint azt az 5.1. ábra illusztrálja. Mivel a frontprofilok rögzítése képpontokban történik, ezért az ábrázolt profilokat át kell konvertálni a valós távolságra a kalibráció segítségével. A front sebessége pedig mindezek után a front helyzetének időbeli változására illesztett egyenes meredekségéből, valamint az egyes felvételek között eltelt időből egyszerúen kiszámolható.

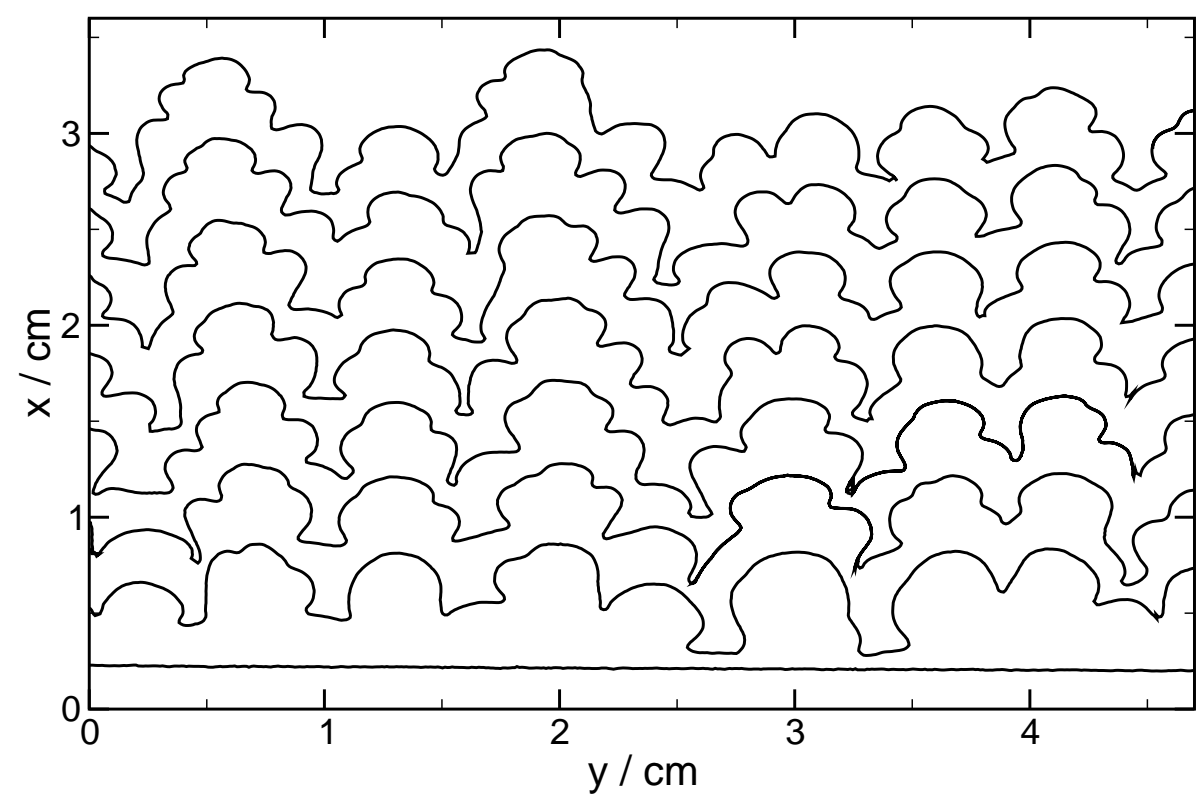

5.1. ábra. A mintázat idôbeli változása.

\subsection{Diszperziós görbe meghatározása}

A laterális instabilitás mennyiségi jellemzése a mintázatképződést leíró diszperziós görbékkel valósítható meg. Az eredetileg sík frontból a kísérleti körülményektől függôen különböző idő alatt alakul ki az előrehaladó és lemaradó szegmensekből létrejövő mintázat. Ezt az 5.2. ábrán látható $\omega-k$ diszperziós görbével tudjuk mennyiségileg jellemezni, ahol a $k$ egy adott hullámszámot jelent, míg az $\omega$ a hozzátartozó növekedési együtthatót. Minden esetben ebből a reakciófront stabilitására tudunk következtetni. A görbék mindig a $(0,0)$ pontból indulnak ki, hiszen a $k=0$ hullámszámú perturbációtól független a síkfront. A pozitív növekedési együttható azt jelenti, hogy az adott hullámszámú kezdeti kísérleti zaj idôben exponenciálisan növekszik, míg negatív együtthatóknál exponenciálisan csökken. Ha mindegyik növekedési együttható értéke negatív, akkor a kezdeti sík alakú front megőrzi stabilitását. Ha van olyan tartomány, ahol a növekedési együttható pozitív, akkor azon hullámhosszú komponensek amplitúdója nô az idővel, vagyis a síkfrontból cellás szerkezet jöhet létre. A 


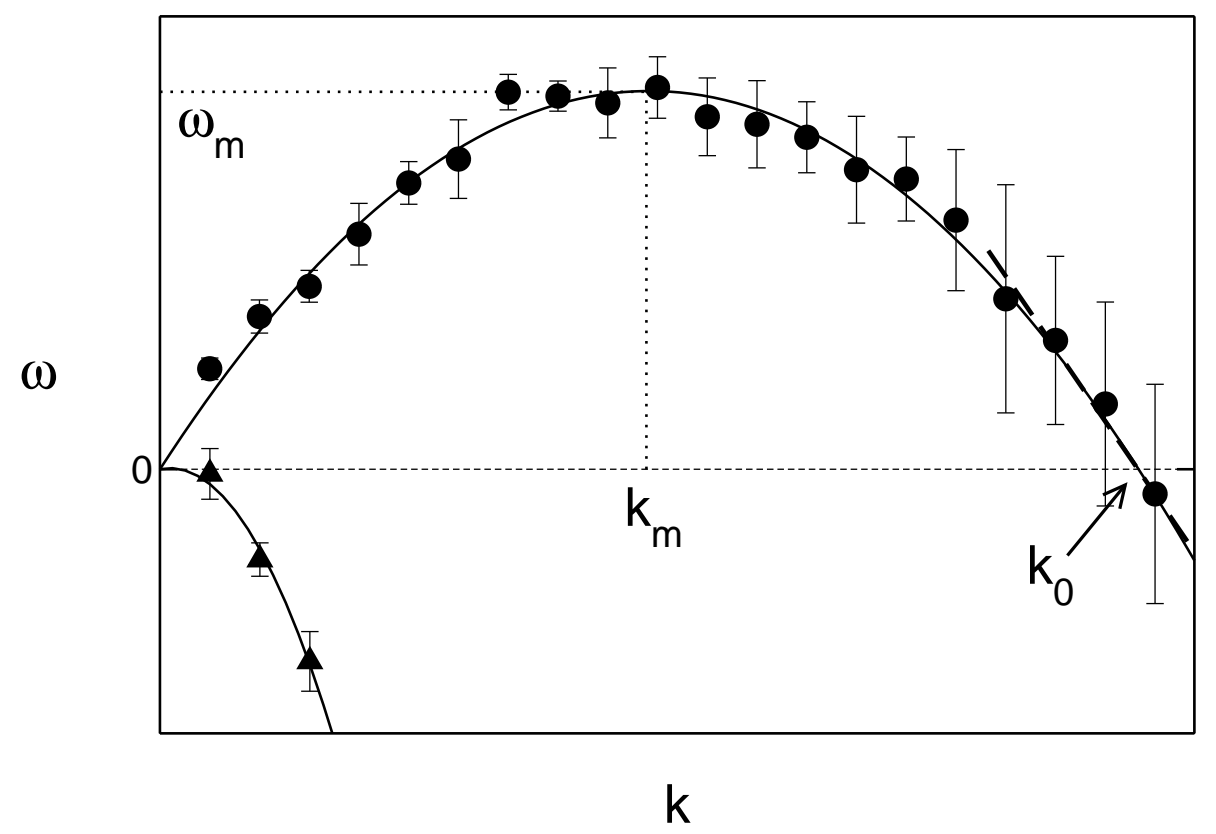

5.2. ábra. A diszperziós görbe sematikus rajza.

növekedési együttható kezdetben nő, majd egy maximális értéket elérve nulláig csökken, miután a csökkenése monotonná válik. A cellás mintázatokra jellemző diszperziós görbéket három számmal lehet jellemezni: a legnagyobb növekedési együtthatóval $\left(\omega_{m}\right)$ és a hozzátartozó hullámszámmal $\left(k_{m}\right)$, illetve a stabil tartományt az instabil tartománytól elválasztó $k_{0}$ marginális hullámszámmal (lásd az 5.2. ábra). A maximális növekedési együtthatóból a legelőször megjelenő, leginstabilabb cellák megjelenésének idejére, míg a hullámszámból a mintázatok hullámhosszára lehet következtetni. Az $\omega_{m}$ a kialakult mintázat legmeghatározóbb pontja, mivel az adott reakciókörülményekre jellemző instabil szerkezetet ez határozza meg a leginkább.

A diszperziós görbe megszerkesztéséhez a frontprofilokon Fourier-transzformáció végrehajtására van szükség, mivel a reakciófront nem más, mint elemi hullámok szuperpozíciója. Ezáltal sikerül a frontalakokat különböző hullámhosszúságú komponensekre felbontani, vagyis megkapjuk az egyes Fourier-együtthatókat és abból a Fourier-amplitúdókat. Az utóbbiaknak a természetes alapú logaritmusát ábrázolva az idő függvényében, majd a kezdeti szakaszra egyenest illesztve, a kapott meredekségek meghatározzák az egyes hullámokhoz tartozó növekedési együttható értékeket. A különböző hullámszám a $k=2 n \pi / L$ képlet alapján számítható ki, ahol $n$ az adott komponenst, az $L$ pedig a kiértékelt tartomány szélességét jelenti. Az instabil tartományba eső növekedési együtthatókra egy origón átmenő parabola illesztése után a $\omega_{m}$ meghatározható. A végső frontalakot leíró diszperziós görbét négy párhuzamos kísérletre kapott görbék átlagaként kaptam meg. 


\subsection{A keveredési hossz és az átlagos frontalak definiálása}

A mintázatok hosszútávú változásának mennyiségi leírása is a célunk volt, ezért bevezettük és definiáltuk a keveredési hosszt $\left(L_{m}\right)$, ami az amplitúdó $(A)$ mellett a másik sokszor használt kvantitatív mennyiség a frontprofilok jellemzésére. Az előbbi az átlagos frontalaktól való átlagos eltérésként definiálható, míg az utóbbi pedig a legelôrehaladottabb és a leglemaradottabb pontok közötti távolságként. A keveredési hossz figyelembe veszi a front összes pontját, míg az amplitúdó csak két pontból jellemzi a reakciófrontot. Így hát előnyösebb a keveredési hossz alkalmazása a mennyiségi kiértékeléshez. Az első lépés az átlagos frontpozíció $(\bar{x})$ meghatározása minden egyes profil esetében, ami az adott idôponthoz tartozó pozíciók átlagát jelenti. Ezután a keveredési hossz

$$
\mathrm{L}_{\mathrm{m}}=\sqrt{\frac{\sum_{\mathrm{i}=1}^{\mathrm{N}}\left(\mathrm{x}_{\mathrm{i}}-\overline{\mathrm{x}}\right)^{2}}{\mathrm{~N}-1}}
$$

egyenlettel számolható, ahol az $x_{i}$ a frontpozíciókat, az $N$ pedig a számoláskor felhasznált képpontsorok számát jelenti. Az amplitúdó és a keveredési hossz között a következő összefüggés áll fenn: $4 \cdot \mathrm{L}_{\mathrm{m}} \approx \mathrm{A}$.

A reakció elején a keveredési hossz nő, majd csak az időben állandó szerkezetek kialakulása után tapasztalható az állandósulása, és ekkor beszélhetünk a stabil alakzat létrejöttéről. Ez az 5.3. ábrán körülbelül a 450. másodperctól valósul meg. A kiértékelést csak az ez utáni adatokra végeztem el. Mindezek után az időben állandó mintázat átlagos frontalakja is megadható az egyes kísérleteknél. Ehhez először is minden egyes számított profilnál a frontalakokból ki kell vonni az átlagos frontpozíciót, mert így ki lehet küszöbölni a front idóbeli

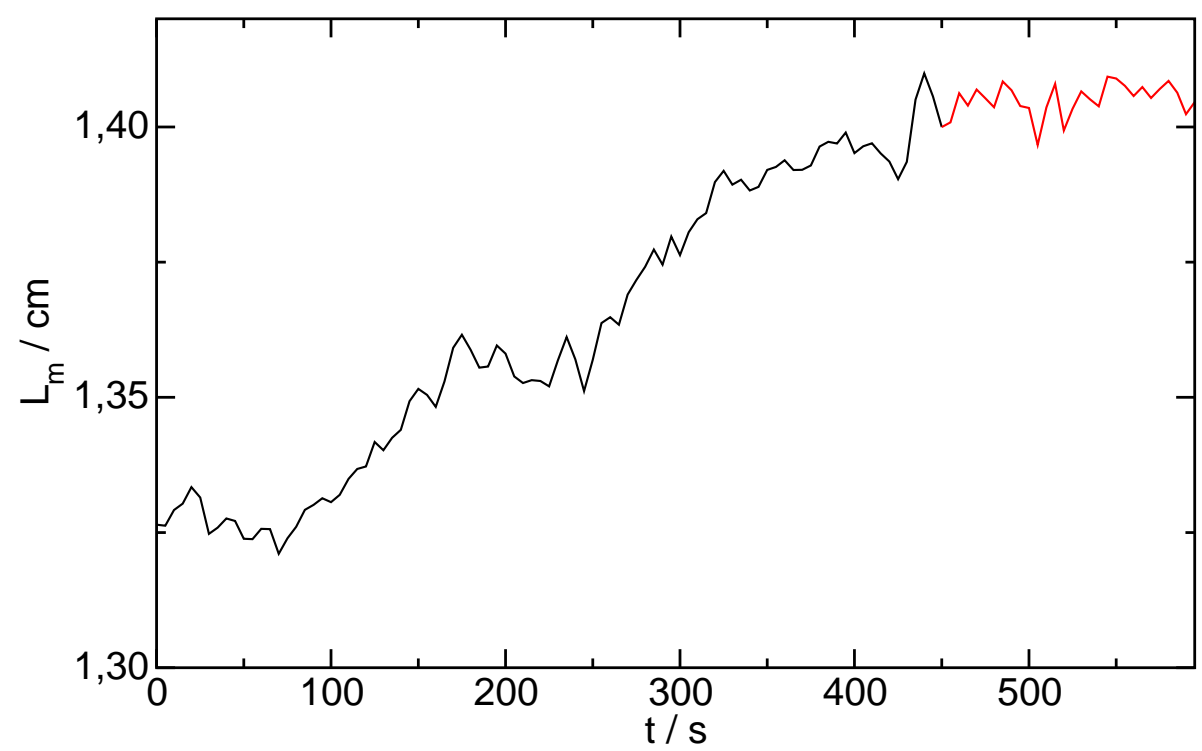

5.3. ábra. A keveredési hossz változása az idő függvényében. 
előrehaladását. A frontpozíciók átlagos helyét mindig az $x=0 \mathrm{~cm}$ koordinátához toltam, majd az alakoknak a front haladási irányára merôleges pontjait idő szerint átlagoltam és szórásukat is meghatároztam. Ekkor az 5.4. ábrához jutottam. Minden egyes kísérletsorozathoz megadtam a keveredési hossz értékeinek átlagát és szórását is általában három párhuzamos kísérlet alapján.

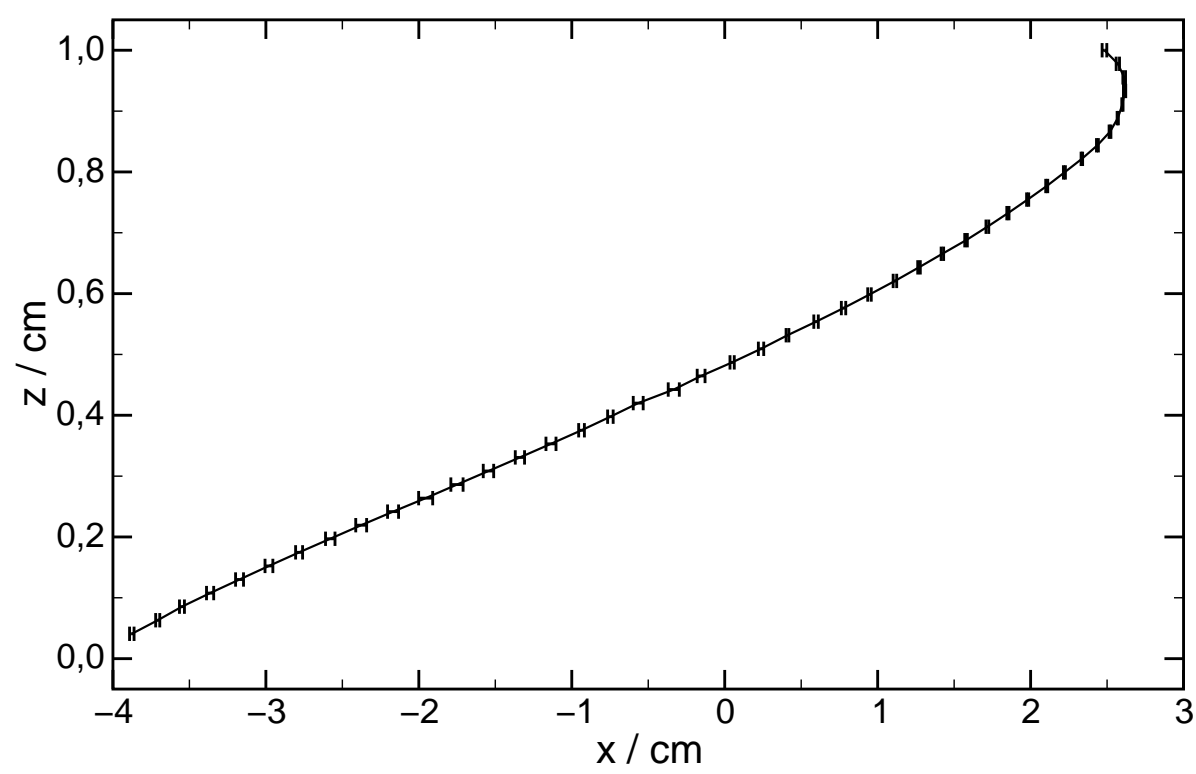

5.4. ábra. A kialakult átlagos frontalak, $L_{m}=2,142 \pm 0,002 \mathrm{~cm}$.

\subsection{Spektrumanalízis}

A különböző összetételú oldatok, illetve a mérendő eleggyel átitatott gélek NMR spektrumát Szegeden vettem fel egy 500 MHz-es készülék segítségével. Néhány megelőző mérés még Debrecenben készült el egy hasonló berendezés alkalmazásával azonos paraméterek mellett. A kapott FIDek-et a kutatócsoportunkban már korábban sikeresen használt GIFA [82] nevú programcsomaggal értékeltem ki. Az alkalmazott gradienstartomány $0-31 \mathrm{G} \mathrm{cm}^{-1}$ közé esett, míg a további paramétereknek a $\delta=2 \mathrm{~ms}$ és a $\Delta=200 \mathrm{~ms}$, illetve a $\delta=4 \mathrm{~ms}$ és a $\Delta=200$ ms értékpárok adódtak, mivel a kis molekulák, valamint a nagy, polimer molekulák esetében más-más értékpár szükséges a kellő pontosságú kiértékeléshez. Az alkalmazott impulzusszekvencia mindig a BPP-LED volt, és a WATERGATE eljárást használtam a mérések során, mert ennek a segítségével sikerült kellóképpen elnyomni az oldószer (víz) jelét, s így a mérni kívánt anyagok jelei jobban láthatóvá váltak.

Az NMR készülék által felvett megfelelő FID beolvasása után a kétdimenziós adatállományon exponenciális apodizációt alkalmaztam - amelynek az értéke $1 \mathrm{MHz}$ volt -, majd 
ezután végrehajtottam az adatsor Fourier-transzformációját is. A kapott spektrumot, a fázisolásának elkészítése után, valós értékűvé konvertáltam. Belső standard hiányában mindent a víz molekula kémiai eltolódásához kalibráltam. Minden mérés 16 darab spektrumot tartalmazott, amelyekből az egyes anyagokhoz tartozó csúcsok maximuma környékéról oszlopokat, vagyis a megfelelő intenzitásokat kivágtam. Ezeket a változó gradienstér függvényében ábrázolva exponenciális lefutású görbék jöttek létre. A jelcsillapodás így a (2.11), StejskalTanner egyenlettel megadható volt, a Wolfram Mathematica programcsomaggal. A gél tartalmú mintáknál az acetátion jelének lecsengése két exponenciális görbe szerint történt, mivel a polimerek jelei közel kerültek hozzá. Ezután már egyszerú volt az exponenciálisok lecsengési együtthatóiból meghatározni a diffúziós koefficienseket. Az egymás után következő sorok is kivágásra kerültek, amik a növekvő gradienstér hatására kialakuló spektrumokat jelentették. Ebből megállapítható volt, hogy nincs-e jeltorzulás a jelintenzitások csökkenése során. A munkám végén szemléltetés céljából kétdimenziós DOSY spektrumokat is készítettem, amelyek a gradienstér tengelye mentén elvégzett inverz Laplace-transzformáció segítségével valósíthatók meg [83]. Ez a transzformáció az exponenciális függvények lineáris kombinációját fejti vissza, és így a különböző diffúziós együtthatókhoz rendeli az egyes egydimenziós spektrumokat. 


\section{6. fejezet}

\section{Eredmények}

\subsection{A laterális instabilitás hatása az autokatalitikus frontra}

\subsubsection{A mintázatképződés eredményei}

A kísérleti munkám során először a diffúzív instabilitást igyekeztem feltérképezni a jodátarzénessav rendszerben. A 6.1. táblázat mutatja be, hogy az egyes komponenseket milyen koncentráció tartományon belül alkalmaztam. Csökkentenem kellett az autokatalizátor hidrogénion diffúzióját annak érdekében, hogy ez a jelenség megjelenjen az adott reakcióban. Mint ahogy azt már az irodalmi áttekintésben is említettem, ennek egyik módja lehet például, ha a rendszerbe immobilis karboxilátcsoportokat építünk be, amik a hidrogénionokat reverzibilis megkötés révén tudják lelassítani. Először, a kutatócsoportunkban a klorit-tetrationát reakció tanulmányozása során már sikerrel alkalmazott [79], poliakrilamid-oldat és nátriumpolimetakrilát-oldat 3:1 arányú keverékét próbáltam ki. Ha csak a diffúzió mintázatra gyakorolt hatását szeretnénk megvizsgálni - ami ebben az esetben nálam is cél volt -, akkor a

6.1. táblázat. A reaktánselegy összetétele.

\begin{tabular}{||l|c||}
\hline \hline$\left[\mathrm{H}_{3} \mathrm{AsO}_{3}\right]_{0} / \mathrm{mM}$ & 50,00 \\
\hline$\left[\mathrm{KIO}_{3}\right]_{0} / \mathrm{mM}$ & 12,90 \\
\hline$[\text { Kongóvörös }]_{0} / \mathrm{mM}$ & 0,57 \\
\hline$[$ Brómfenolkék $]]_{0} / \mathrm{mM}$ & 0,16 \\
\hline$[\mathrm{Na}-\mathrm{PA}]]_{0} / \mathrm{mM}$ & $0,0-74,40$ \\
\hline$[\text { PAA-PMA }(3: 1)]_{0} / \mathrm{g} \mathrm{cm}^{-3}$ & $0-28,80$ \\
\hline \hline
\end{tabular}


rendszerben a különböző sûrúségú folyadékok jelenléte miatt az óhatatlanul fellépô közegmozgást ki kell küszöbölni. A metakrilátot tartalmazó oldat alkalmazása továbbá ezért is jó lehet, mivel a mennyiségét növelve az oldat viszkozitásának növekedésével a konvekció mértéke csökken [23]. Az eredményeket összegezve elmondható, hogy 51\%-os hidrogénionmegkötést elérố polimer keveréket alkalmazva nem lehet megfelelően lecsökkenteni az autokatalizátor látszólagos diffúzióját, ahogyan az a 6.1. (a) ábrán is látható, hiszen a vízszintesen haladó síkfront megőrzi alakját. A karboxilát tartalmú polimeroldat mennyiségét még tovább növelve viszont már nem lehet a reakciófrontot elindítani, mivel a reakció előrehaladásához szükséges kellő mennyiségú hidrogéniont megköti.

Ezen reakcióban a reaktáns sûrúsége nagyobb, mint a reakcióterméké, és ez azt eredményezi, hogy a fentről lefelé haladó front hidrodinamikailag stabil lesz. Ekkor a kezdetben planáris front megôrzi sík alakját, ahogy az a 6.1. (b) ábrán is látszik 33 perccel az indítás után. Abban az esetben viszont, amikor a front felfelé halad, a nagyobb sưrúségú reaktánsoldat belesüllyed a kisebb sû́rúségú termékoldatba, és ez közegmozgást idéz elő. Mindezt pedig a 6.1. (c) ábra szemlélteti.

Ezek után áttértem egy másik karboxilát tartalmú vegyület alkalmazására, amivel már kellőképpen le lehetett lassítani a hidrogénion diffúzióját. Ez a nátrium-metakrilát tartalmú poliakrilamid-gél a konvekciómentes közeg biztosítására is megfelelő volt. A frontprofilok időbeli változása a 6.2. (a) ábrán látható, ahol a hidrogénionok 75\%-át megkötô gélt használtam. A kezdetben meglevő eltérések a reakció előrehaladásával felerősödtek, és ez két, centiméter nagyságrendû hullámhosszal és $7-8 \mathrm{~mm}$ amplitúdóval rendelkező cella kialakulását indukálta. A másik autokatalizátor, a jodidion pufferált közegben $\alpha$-ciklodextrinnel [9] való megkötésénél (lásd a 6.2. (b) ábrán) jóval nagyobb amplitúdójú cellákat sikerült létrehozni a hidrogénion szelektív immobilizálásával karboxilátcsoportokat tartalmazó poliakrilamidgélben. Elmondható, hogy a IAA rendszerben kimutatható kísérletileg a diffúzív instabilitás

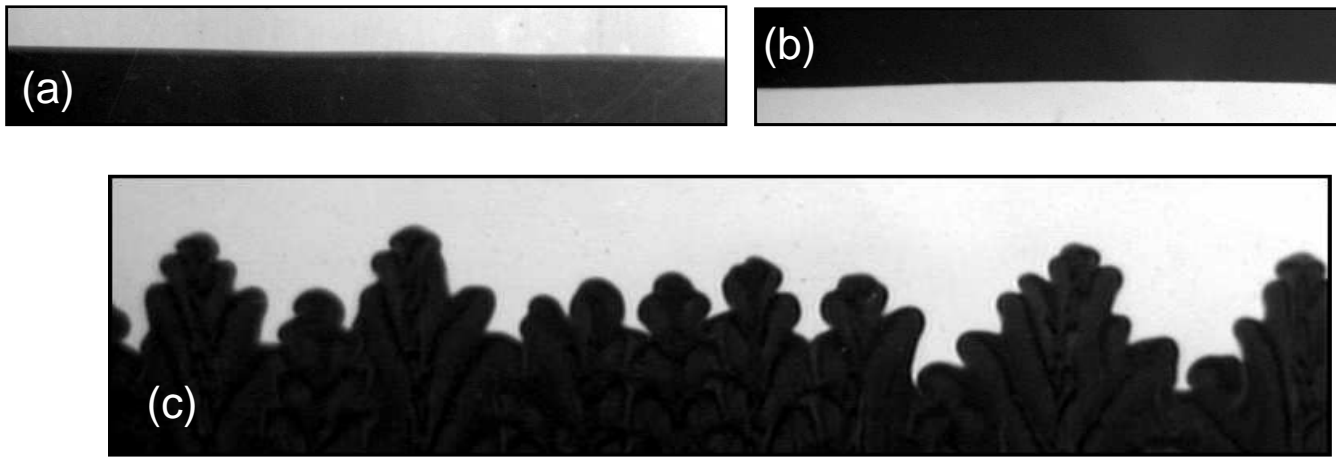

6.1. ábra. Vízszintesen (a), lefelé (b), és felfelé (c) haladó frontok képe karboxilátcsoportokat tartalmazó polielektrolit-oldatokban. A sötét rész a termék-, míg a világos részek a reaktánselegynek felelnek meg. A felvételek szélessége $8,2 \mathrm{~cm}$. 

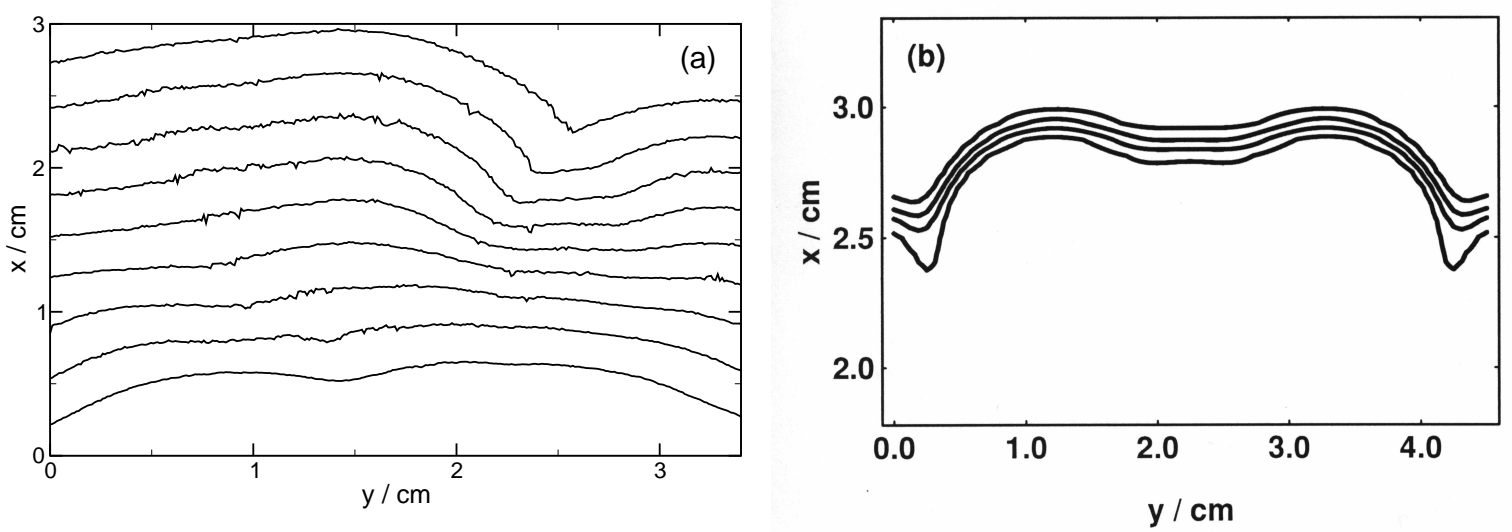

6.2. ábra. A hidrogénionok és a jodidionok 75\%-os megkötése során [9] kialakuló cellás szerkezetek láthatók.

csak a hidrogénionok megkötése révén is. Ezek után valószínúsíthető, hogy ha a két autokatalizátor közül csak a hidrogénionokat kötjük meg, és a jodidionok továbbra is a stabil síkfront fenntartásáért diffundálnak gyorsabban, akkor az első folyamat válik az uralkodóvá, azaz a hidrogénionok lassítása, hiszen az idő előrehaladtával cellás alakokat kaptam. Ennek az a magyarázata, hogy a két autokatalizátor együttesen van jelen az adott rendszerben, valamint az, hogy ezek közül az egyik a hidrogénion, aminek vizes oldatban nagy a mozgékonysága [84].

Vékony - 0,4 mm vastagságú - oldatrétegben vízszintesen haladó front esetében is elvégeztem a kísérletet, ahol a képződő hidrogénionok 80\%-át nátrium-poliakrilát-oldattal kötöttem meg. Azt tapasztaltam, hogy több óra után is sík maradt a kezdeti frontprofil, és ez a 6.3. ábrán is jól látszódik. Arra lehet következtetni, hogy a mintázatképződésre nagy hatást gyakorol a közegben levő polimer mérete és szerkezete. Ezek után a térhálósító anyag mennyiségét változtattam, és megvizsgáltam ennek a hatását. E célból a poliakrilamidok esetében leggyakrabban alkalmazott térhálósító anyagot, az N,N'-metilén-bisz-akrilamidot használtam. A mennyiségét nulla és $0,2 \mathrm{~g}$ között variáltam. A kapott polimerekrôl elmondható, hogy a térhálósító anyag mennyiségének növelésével merevebb, jobban kezelhető, vághatóbb tulajdonságúak lettek. Azt tapasztaltam, hogy ha az N,N'-metilén-bisz-akrilamid mennyiségét megnöveltem, akkor a front stabilitása megszúnt, és ez cellás szerkezeteket eredményezett. Az instabilitásbeli különbség nem olyan meghatározó a 6.4. ábra két képe között. A némileg nagyobb fokú torzulást a több keresztkötés okozza a több mennyiségben N,N'-metilén-biszakrilamidot tartalmazó gélnél, hiszen itt az autokatalizátor előrejutása nagyobb mértékben van akadályozva. Azonban az eltérés a kiindulási sík alakzat és a létrejövő mintázat között már jobban szembetúnik. Mindkét gél esetében jól látható a kezdeti sík alakú fronttól való eltérés. Megállapítható, hogy a térhálósító anyag mennyiségének változtatása hatással van a 


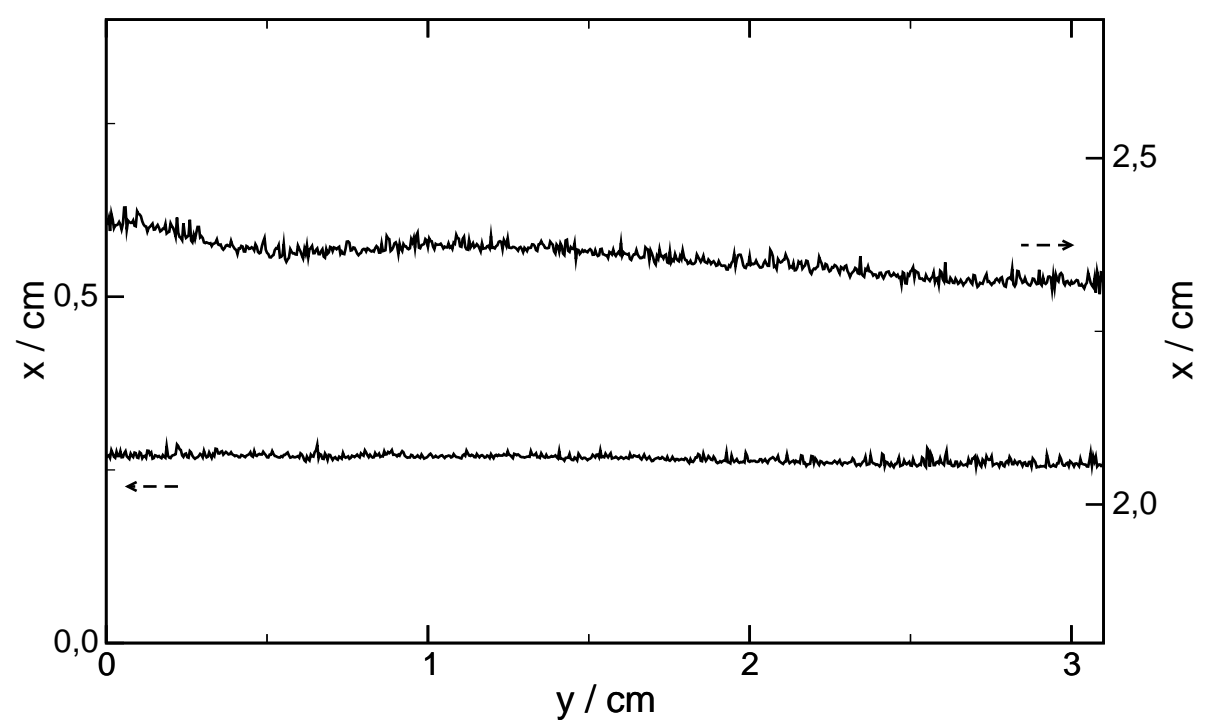

6.3. ábra. Az oldatban 3 óra 15 perc után létrejövő frontprofil a képződő hidrogénionok 80\%-os megkötése esetén.

kiindulási síkfrontra, ugyanis frontprofil-változás figyelhető meg.

A kezdetben létrejövő mintázat mennyiségi leírására meghatároztam a diszperziós görbéket a 6.3. és a 6.4. ábrákon bemutatott kísérletek esetében, amik a 6.5. ábrán kerültek reprezentálásra. Leolvasható a görbékről, hogy a gélminták esetében (a $\square$ és a $\diamond$ ) a kezdetben meglévő kísérleti zaj időben exponenciálisan nôtt, vagyis a növekedési együttható egy adott hullámszám-tartományon belül pozitív lett. Itt is az látható, hogy a több térhálósítót tartalmazó gélben lejátszatott reakció esetében a mintázat kialakításában valóban a kisebb hullámhosszak játszottak szerepet $(\diamond)$, hiszen a görbe maximuma a nagyobb hullámszámnál van. A $\square$ görbe maximuma magasabban van, mint a $\diamond$ görbéjé, vagyis egy kicsivel rövidebb
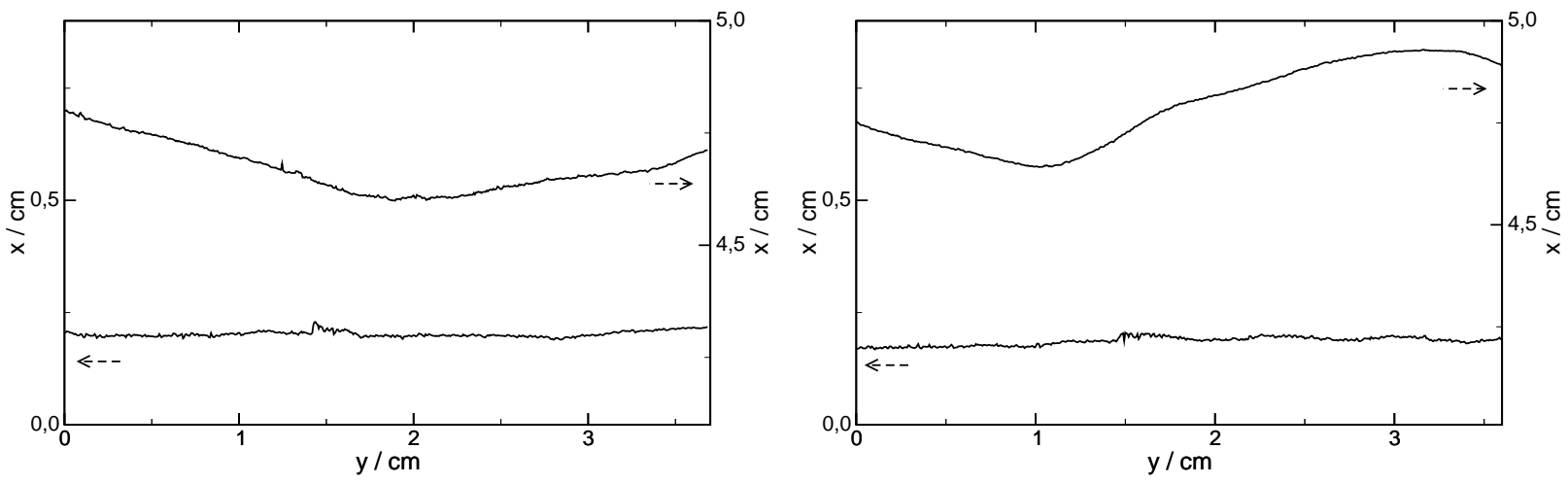

6.4. ábra. Baloldalt $0,075 \mathrm{~g} \mathrm{~N}, \mathrm{~N}$ '-metilén-bisz-akrilamidot tartalmazó gélben 65 perc alatt kialakult front, míg jobboldalt 0,2 g-ot tartalmazó gélben 75 perc után létrejött cellás szerkezet látható. 


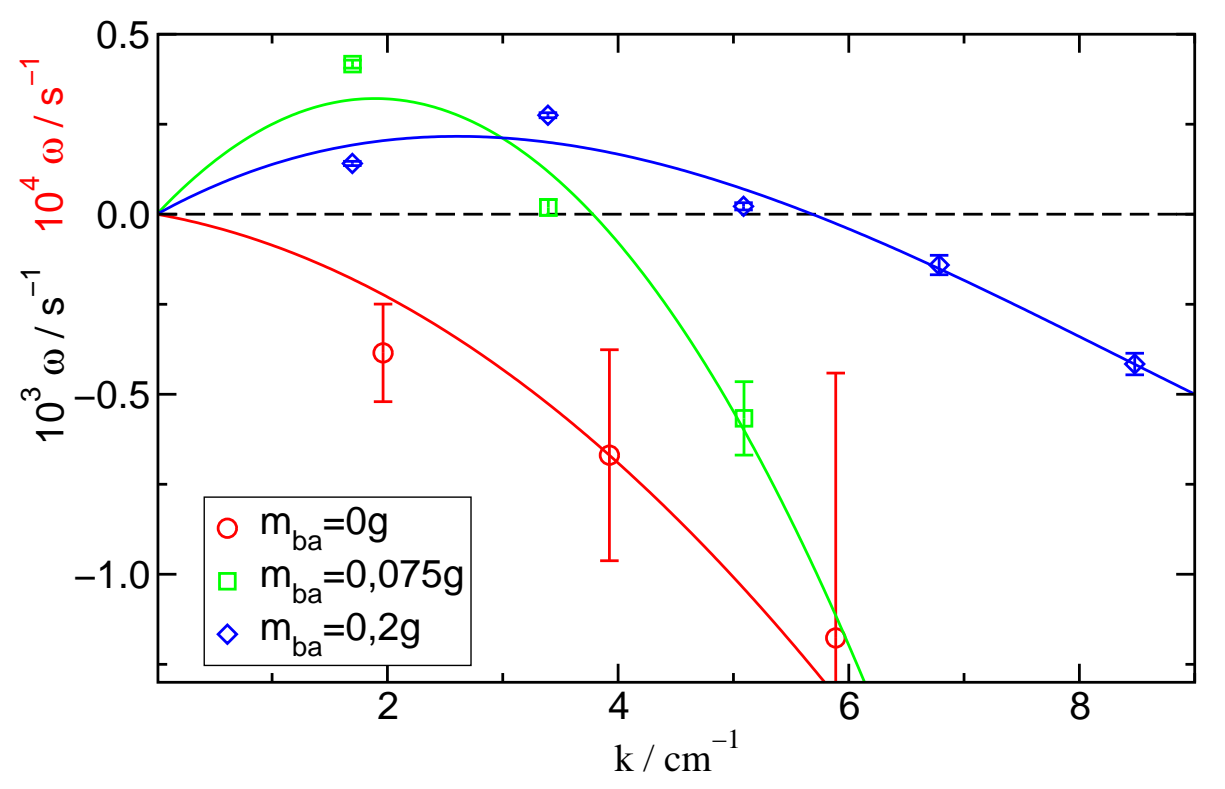

6.5. ábra. A vízszintesen haladó frontok diszperziós görbéi.

idő alatt alakult ki az instabilitás. A piros görbénél exponenciálisan csökkenő zaj fedezhető fel, mivel a növekedési együttható értékek negatívak, és ez azt jelenti, hogy stabil front jött létre, ahogyan azt a frontprofilok is mutatták.

Az irodalomban azt olvashatjuk, hogy a diffúzív instabilitás mértéke csökken egy megkötési értéken túl, vagyis a képződő hidrogénion immobilizálása nem növelhetô határtalanul [85]. Kísérletileg ugyanezt tapasztaltam, hiszen 80\%-ra növelve a megkötést kisebb amplitúdójú és kisebb hullámhosszú cellákat kaptam, mint mikor 75\%-os megkötést alkalmaztam (lásd a 6.2. ábrát és a 6.4. ábrát), hiszen kisebb amplitúdójú és kisebb hullámhosszú cellák jöttek létre a megkötés növelésével. Ez úgy lehetséges, hogy a reverzibilis megkötés révén csökken a szabad hidrogénion mennyisége, ami befolyásolja a reakció sebességét, ami viszont a frontsebességre közvetlen hatást fejt ki. A front sebessége lassabb lesz azáltal, hogy csökken a reakciósebesség, és ennek hatására az autokatalizátor negatív visszacsatolása kisebbé válik. A nagymértékú megkötés jelentôsen visszafogja az autokatalízist, és így a két hatás jelentősen gyengíti egymást. Mindezek alapján elmondható, hogy létezik egy kritikus megkötőanyag koncentráció, amelyet alkalmazva a legnagyobb lesz az instabilitás mértéke [84], mivel az autokatalizátor fluxusának kívánt mértékú csökkentése a reakció sebességét túlságosan lecsökkenti.

\subsubsection{Az NMR-mérés eredményei}

Az egyes reakcióközegekben meghatároztam a diffúziós viszonyokat, vagyis a kinetikai szempontból számomra fontos komponensek diffúziós együtthatóját. A célom az volt, hogy 
a dolgozatomban megadjam a nátrium-acetátnak - mint mobilis hidrogénion megkötő ágensnek - az alkalmazott reakciókörülmények között fennálló diffúziós együtthatóját. Továbbá meg szerettem volna ismerni a különböző polimereket tartalmazó közegek diffúziós viszonyait is, hogy a mintázatképződés eredményeit alátámaszthassam.

A gradienstér hiányában az oldószer jelének elnyomásával felvett egydimenziós spektrumokon kellố mértékben beazonosíthatók az egyes komponensekhez tartozó NMR-csúcsok. A 6.6. ábrán a nátrium-poliakrilátot tartalmazó oldat esetében kapott egydimenziós spektrum látható. A nátrium-acetát jele 1,9 ppm-nél található, ahogy arra számítani lehetett az irodalmi adatok alapján [86], míg a nátrium-poliakrilát csúcsai 1,2 - 1,7 és 1,9 - 2,2 ppm között elkülönülten jelennek meg. Egyértelmú, hogy a molekulatömeg növekedésével az egyes alkotóelemek diffúziós koefficiense csökken, mivel a nagyobb komponensek a méretuik miatt csak lassabban képesek diffundálni. Ezt bizonyítják a kapott mérési eredmények is, amiket a 6.2. táblázatban foglaltam össze. Az adatok alapján elmondható, hogy a savas és a bázikus oldatok esetén kicsi a különbség az egyes komponensek esetében mért diffúziós koefficiensek között [11], ezért ezt követően már csak a reaktánselegyekben végeztem el az in situ PFGSE-NMR méréseket.

A 6.7. ábra már a 0,075 g térhálósítót tartalmazó gél 1D-NMR spektrumát szemlélteti. Ezen az ábrán a polimerek jelei 1,2 - 3,8 ppm tartományban találhatóak, míg az akrilamid monomerjelei 5,8 és 6,5 ppm-nél [87], a nátrium-metakrilát pedig 1 ppm körül jelenik meg. Az arzénessavnak egy jele van, ami nem határozható meg egyértelmúen, mivel a víz jele mellett helyezkedik el 4,7 - 5,2 ppm-nél [88]. Ez egy vállszerú kiemelkedésként észlelhető a vízjel mellett a 6.7. ábrán.

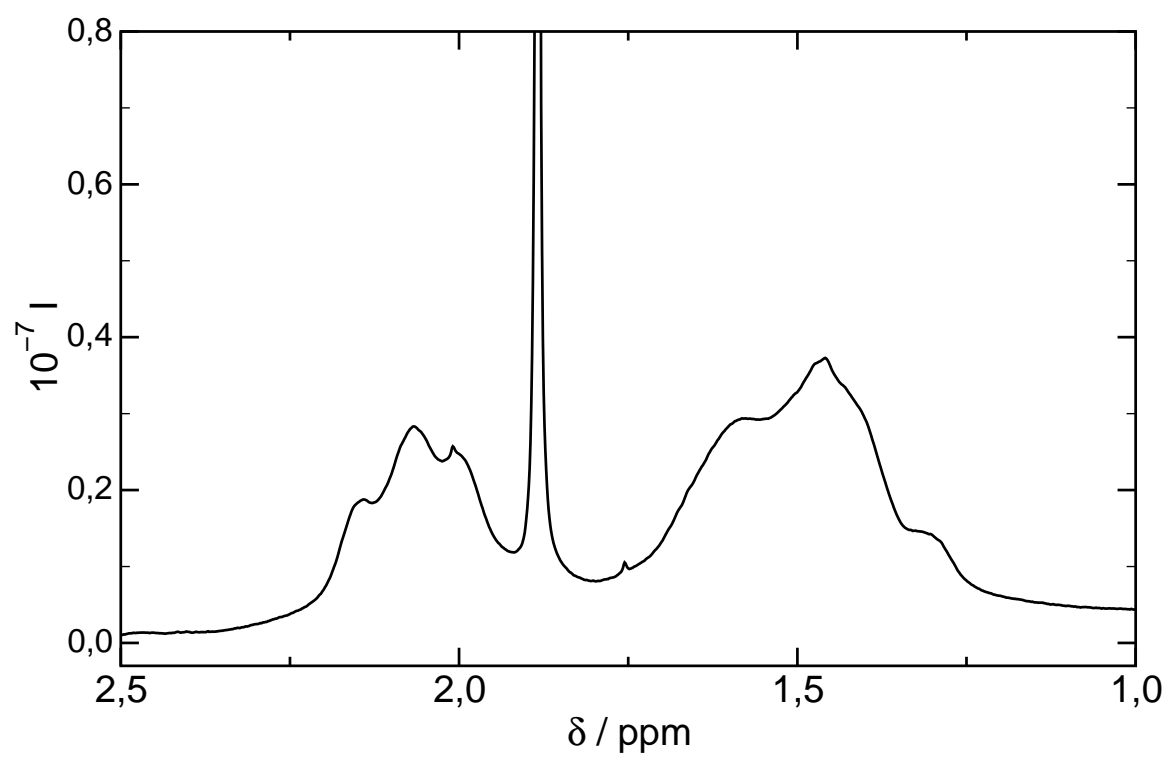

6.6. ábra. A nátrium-poliakrilátot tartalmazó minta egydimenziós ${ }^{1} \mathrm{H}-\mathrm{NMR}$ spektruma. 
6.2. táblázat. A mért diffúziós koefficiensek a 4.2. táblázatban feltüntetett összetétel esetén.

\begin{tabular}{||l||c|c||}
\hline \hline & $D_{\text {lúgos }} / \mathrm{cm}^{2} \mathrm{~s}^{-1}$ & $\mathrm{D}_{\text {savas }} / \mathrm{cm}^{2} \mathrm{~s}^{-1}$ \\
\hline \hline Acetát / ecetsav & $(1,21 \pm 0,01) \cdot 10^{-5}$ & $(1,17 \pm 0,01) \cdot 10^{-5}$ \\
\hline Brómfenolkék & $(4,8 \pm 0,3) \cdot 10^{-6}$ & $(4,9 \pm 0,2) \cdot 10^{-6}$ \\
\hline Poliakrilát / poliakrilsav & $(3,64 \pm 0,06) \cdot 10^{-7}$ & $(3,57 \pm 0,09) \cdot 10^{-7}$ \\
\hline \hline
\end{tabular}

Ahogy a gradienstér erôssége nő, úgy csökken a jelek intenzitása is. Ez a csökkenés értelemszerúen jelentősebb mértékú az acetátionnál, mint a különböző polimereknél, hiszen a kis molekulák gyorsabban diffundálnak. A 6.8. ábrán az is jól megfigyelhetô, hogy nincs jelalak torzulás a növekvő gradienstér hatására fellépő intezitáscsökkenésben.

A 6.9. ábrán látható DOSY-spektrum jól illusztrálja, hogy különböző sebességû diffúzióval haladnak előre az egyes anyagfajták az oldatokban. Szinte mindegyik célanyagnak elkülöníthető volt egy-egy csúcsa. Ezek intenzitásának a lecsengése egy exponenciális függvénnyel jellemezhetô a (2.11) egyenlet szerint, és ebből már a diffúziós együttható könnyen kiszámolható.

Már a korábbi mérések során észleltem, hogy a kis molekula és a különféle polimerek diffúziós koefficiense olyan mértékben különbözik egymástól, hogy nem lehetséges mind a polimerekre, mind pedig a nátrium-acetátra egyidőben jól értékelhetô spektrumot kapni. Így

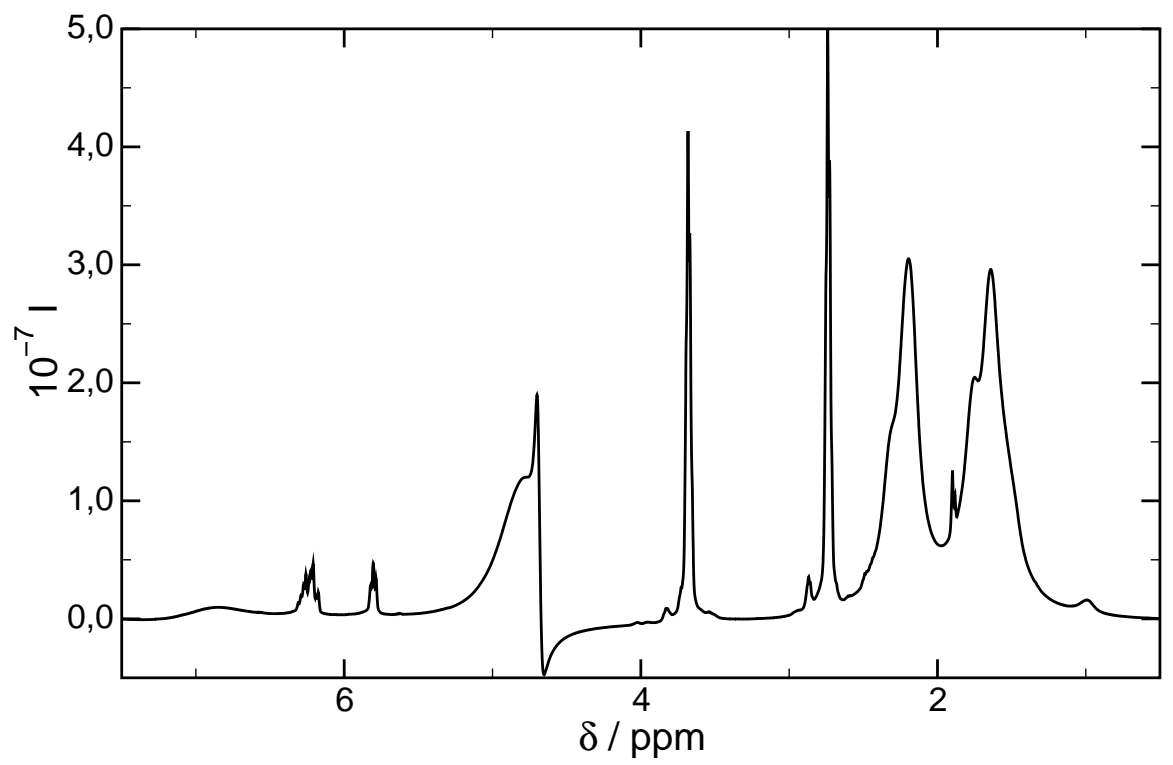

6.7. ábra. A 0,075 g térhálósítót tartalmazó minta egydimenziós ${ }^{1} \mathrm{H}-\mathrm{NMR}$ spektruma. 

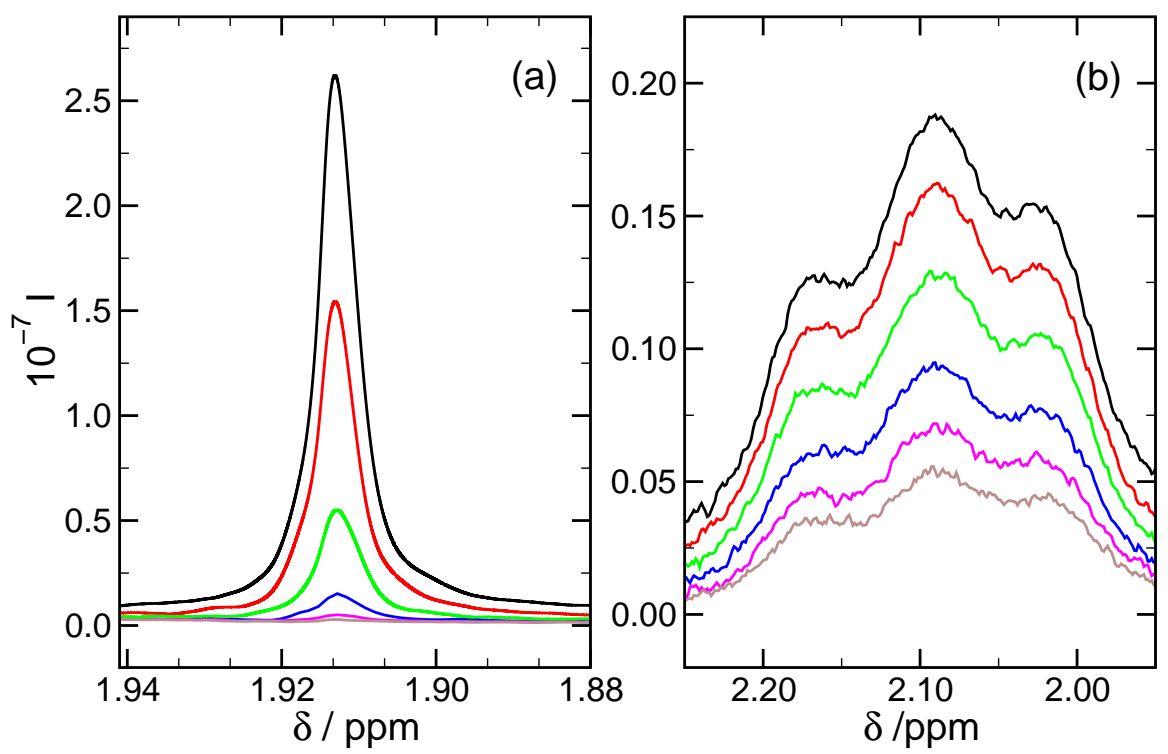

6.8. ábra. A jelintenzitás csökkenése (a) acetátion, (b) nátrium-poliakrilát esetében.

ugyanazon a mintán különböző mérési körülmények során végrehajtott többszöri mérése ad megfelelő eredményt. Eltérő $\Delta$ (a gradiensimpulzusok adásának kezdete között eltelt idő) és $\delta$ (a gradiensimpulzus időtartama) értékpárok használatára volt szükség, és ekkor már megfelelő lecsengésú spektrumokat lehetett rögzíteni. Az, hogy mennyire exponenciális lefutású a jelintenzitás csökkenése, a 6.10. ábra mutatja be az acetátionra egy megkötés nélküli reaktánsoldatnak megfelelő mintában.

Az illesztésből az egyes mintákra meghatározott diffúziós koefficiensek értékét a 6.3.

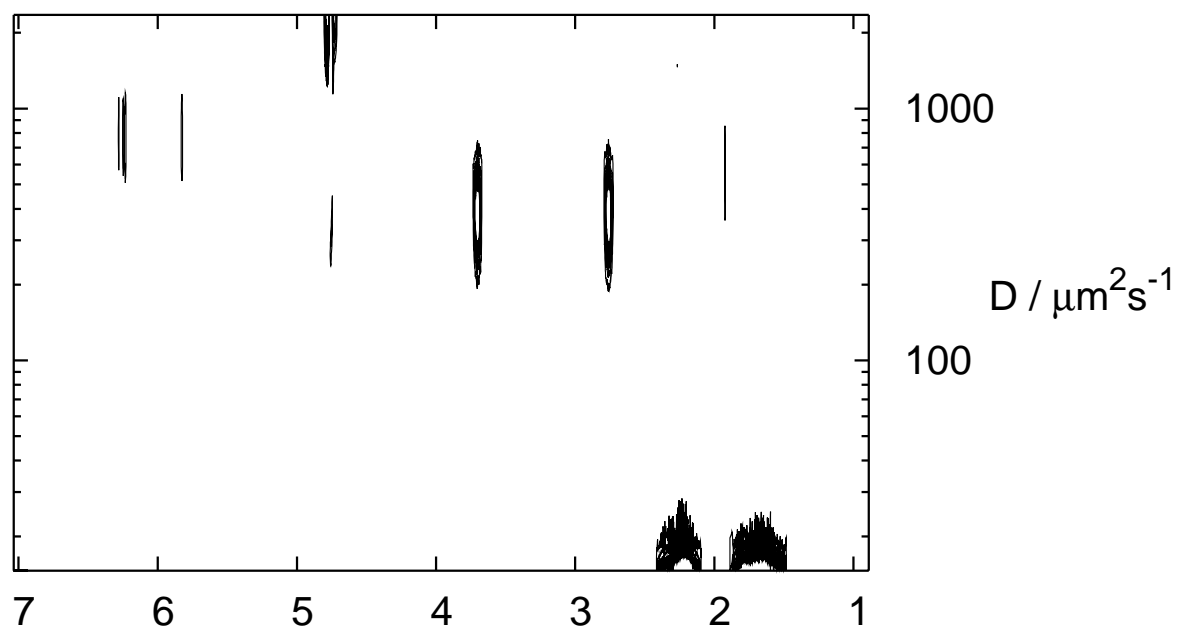

$\delta / \mathrm{ppm}$

6.9. ábra. A 0,075 g térhálósítót tartalmazó minta ${ }^{1} \mathrm{H}$-DOSY spektruma. 


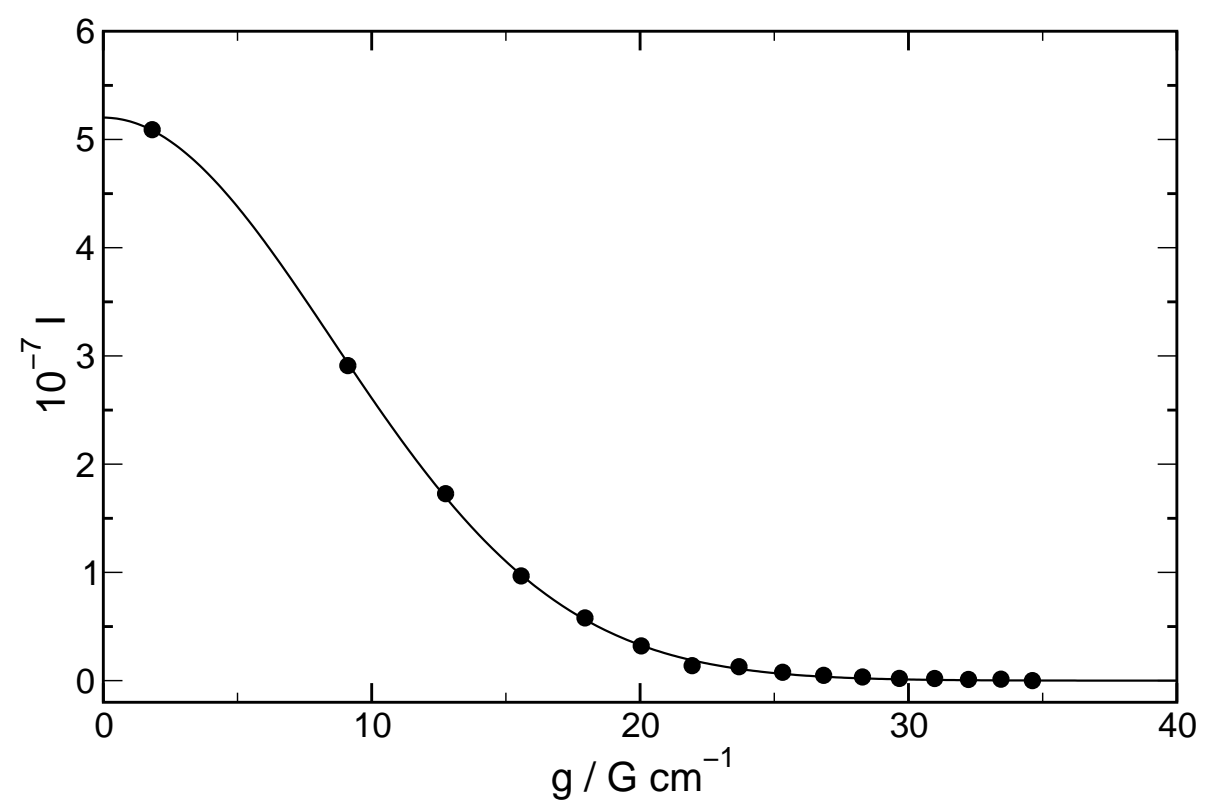

6.10. ábra. A jelintenzitás exponenciális csökkenése a növekvő gradienstér függvényében az acetátionnál.

táblázatban foglaltam össze. A mérésre került négyféle minta összetételét még korábban a 4.3. táblázatban adtam meg. Ezeket a mintákat a mintázatképződés során tapasztalt eredmények alapján választottam ki NMR mérésre. Mivel a brómfenolkék diffúziós együtthatóját már korábban megmértem, így ezt most nem vizsgáltam. Az N,N'-metilén-bisz-akrilamid monomer csúcsainak jelintenzitás-csökkenéséből számolt diffúziós koefficiense a 0,075 g térhálósítót tartalmazó gélben $(6,74 \pm 0,07) \cdot 10^{-6} \mathrm{~cm}^{2} \mathrm{~s}^{-1}$, míg a 0,2 g-ot tartalmazónál $(5,88 \pm 0,05) \cdot 10^{-6} \mathrm{~cm}^{2} \mathrm{~s}^{-1}$ volt. Az akrilamid-N,N'-metilén-bisz-akrilamid kopolimer jelei

6.3. táblázat. A mért diffúziós koefficiensek a jodát-arzénessav rendszerben. Az egyes minták pontos összetétele a 4.3. táblázatban található.

\begin{tabular}{||l||c|c|c||}
\hline \hline \multirow{2}{*}{\multicolumn{1}{||}{ Minta }} & \multicolumn{3}{c||}{$\mathrm{D} / \mathrm{cm}^{2} \mathrm{~s}^{-1}$} \\
\cline { 2 - 4 } & Poliakrilát & Acetát & Polimerek \\
\hline \hline Reaktánsoldat & - & $(1,21 \pm 0,01) \cdot 10^{-5}$ & - \\
\hline Na-PA-os oldat & $(5,8 \pm 0,1) \cdot 10^{-7}$ & $(1,12 \pm 0,01) \cdot 10^{-5}$ & - \\
\hline 0,075 g bisz-akrilamid & - & $(6,5 \pm 0,1) \cdot 10^{-6}$ & $(1,7 \pm 0,1) \cdot 10^{-8}$ \\
\hline 2 g bisz-akrilamid & - & $(5,5 \pm 0,3) \cdot 10^{-6}$ & $(2,2 \pm 0,2) \cdot 10^{-8}$ \\
\hline \hline
\end{tabular}


egy helyre esnek, ezért a számolt diffúziós együttható a két polimer $D$-jának az átlagaként adódott, és ez található a 6.3. táblázat utolsó oszlopában.

A nátrium-poliakrilátot tartalmazó minta esetében a mobilis hidrogénion megkötő nátrium-acetát mozgékonyságát még nem lehetett kellő mértékben lelassítani. Ez látszik a mért diffúziós együtthatójából is, ami szinte megegyezik a reaktánsoldatnak megfelelő vizes oldatban kapott értékkel (lásd a 6.3. táblázat harmadik oszlopa). A géles mintáknál megfigyelve a kapott értékeket elmondható, hogy az acetátion diffúziója csak fél nagyságrenddel lassabb, mint az előbbi esetekben. Ez még egymagában nem tud magyarázatot adni a cellás szerkezet felbukkanására, de ha figyelembe vesszük a táblázat utolsó oszlopát is, ami az előrehaladás további csökkenését mutatja, akkor az egyidejúleg fellépő csökkentő hatás már bizonyíték értékú. A negyedik mintánál a legkisebb az acetátion diffúziós együtthatója, ami instabilabb szerkezetek kialakulását eredményezheti $0,2 \mathrm{~g} \mathrm{~N}, \mathrm{~N}$ '-metilén-bisz-akrilamid használatakor. Továbbá az is észrevehetô az adatok alapján, hogy az acetátionra és a polimerekre kapott diffúziós együtthatók egymáshoz viszonyított aránya nagyobb, körülbelül 380 a kevesebb térhálósító anyagot tartalmazó minta esetében, mint a másik esetben, ahol a számszerúsített arány 250. Ez is hozzájárul a kisebb hullámhosszú cellák kialakulásához.

\subsection{A konvektív instabilitás hatása}

\subsubsection{A skálázási törvény érvényessége}

A következő fejezetben a sûrúségváltozás következtében fellépő közegmozgás mintázatra gyakorolt hatásának tanulmányozásakor észlelt megfigyeléseimet mutatom be. Elegendően hosszú és keskeny reakcióedényben állandó sebességgel terjedő állandó alakzatok jöttek létre, amelyek mennyiségi leírására a mintázat elnyúlását jellemző keveredési hossz alkalmazható, ahogyan azt már korábban definiáltam. Rongy [75] és társai elméleti számítások során megjósolták, hogy a $L_{m}$ a reakcióedény magasságának második hatványával arányos. Az elmélet kísérletileg való alátámasztásának céljából meghatároztam a skálázási törvényt a jodát-arzénessav autokatalitikus reakcióban olyan kémiai összetétel mellett, ahol a jodátion még nem redukálódott teljesen jodidionná. A kísérletek során három kiindulási koncentrációarányt $(\mathrm{R})$ alkalmaztam, amik a 6.4. táblázatban láthatóak. Az indikátor ebben az esetben, a reakcióban képződött $\mathrm{I}_{2}, \mathrm{I}_{3}^{-}$sárga színe volt.

A mintázat hosszútávú viselkedésének tanulmányozására a vékony folyadékrétegek kialakítását lehetôvé tevő, a 4.4. ábrán bemutatott Hele-Shaw cellát használtam, amit egy optikai padon függőlegesen helyeztem el. Ezen kísérletek során a plusz falakat nem építettem be a rendszerbe, illetve az edény magasságát 1 és $4 \mathrm{~cm}$ között változtatva tanulmányoztam az előrehaladó frontokat a képfeldolgozó rendszer segítségével. Minden esetben meghatá- 
6.4. táblázat. A reaktánselegy összetétele a IAA rendszerben $\left(\mathrm{R}=\left[\mathrm{H}_{3} \mathrm{AsO}_{3}\right]_{0} /\left[\mathrm{KIO}_{3}\right]_{0}\right)$.

\begin{tabular}{||l||c|c|c||}
\hline \hline $\mathrm{R}$ & 3,9 & 2,8 & 2,6 \\
\hline \hline$\left[\mathrm{KIO}_{3}\right]_{0} / \mathrm{mM}$ & 12,9 & 12,9 & 12,9 \\
\hline$\left[\mathrm{H}_{3} \mathrm{AsO}_{3}\right]_{0} / \mathrm{mM}$ & 49,9 & 36,1 & 33,5 \\
\hline $\mathrm{pH}$ & 7,0 & 7,0 & 7,0 \\
\hline \hline
\end{tabular}

roztam az átlagos frontpozíciótól való átlagos eltéréseket $\left(L_{m}\right)$ a különböző kémiai összetételeknél 25, illetve $4{ }^{\circ} \mathrm{C}$-on. Megmértem a konvekciót előidéző sưrüségváltozást is. A kapott sûrúség adatokat a 6.5. táblázat tartalmazza. Jól látszódik, hogy a reaktánsoldat sưrúsége mindig nagyobb a termékoldaténál, és ennek következtében a reaktánselegy a termékelegy alá csúszik, vagyis a konvekció eredményeképpen torzul a két oldat közti határvonal. A kezdeti koncentrációarány növekedésével csökken a reaktáns és a termék közötti sûrúségbeli különbség. Az $\mathrm{R}=$ 2,6-os arány esetében szilárd jód válik le a termékoldatban, és ez eredményezheti, hogy több mint háromszorosára nő az ehhez tartozó $\Delta \rho$ az összes többi sûrúségkülönbséghez viszonyítva. Ez játszhat szerepet a sokkal elnyúltabb frontalakzatok megjelenéséért. A $4{ }^{\circ} \mathrm{C}$-on 2,8-as aránynál mért értékek közti különbség a hőelvonás hatására csökkent, hiszen csak a kémiai összetétel változásából eredô súrúségváltozás lép fel ebben az esetben.

6.5. táblázat. Az egyes oldatok sưrúsége különbözô hőmérsékleteken $\mathrm{g} \mathrm{cm}^{-3}$ egységben kifejezve.

\begin{tabular}{||c||c|c|c|c||}
\hline \hline $\mathrm{R}$ & $\mathrm{T} /{ }^{\circ} \mathrm{C}$ & $\rho_{r}$ & $\rho_{t}$ & $\Delta \rho$ \\
\hline \hline 3,9 & 25 & 1,00643 & 1,00620 & $-0,00023$ \\
\hline 2,8 & 25 & 1,00449 & 1,00429 & $-0,00020$ \\
\hline 2,8 & 4 & 1,00769 & 1,00754 & $-0,00015$ \\
\hline 2,6 & 25 & 1,00405 & 1,00333 & $-0,00072$ \\
\hline \hline
\end{tabular}

Az első választott reagens arányom 3,9 volt, ahol végtermékként jodidionok képződtek. A kifejlődött stabil frontalakot a 6.11. ábra illusztrálja. A frontot a vékony, fekete vonal

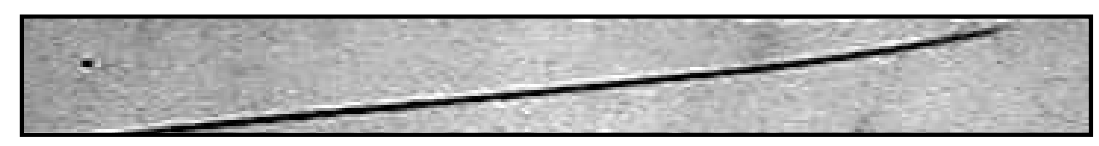

6.11. ábra. $A z R=3,9$ arány esetében $1 \mathrm{~cm}$ magas edénynél konstans alakkal bíró balról jobbra haladó reakciófrontról szobahőmérsékleten készült fénykép $\left(L_{m} / \mathrm{cm}=2,22 \pm 0,02\right)$. 
reprezentálja, amely alátámasztja, hogy a jód minimális köztitermékként keletkezett a reakcióban. A skálázási törvény nem más, mint a keveredési hossz és a reakcióedény magassága közti összefüggés, ami ebben az esetben a 6.12. ábrán figyelhető meg.

Meghatároztam az illesztett görbét, azaz azt az összefüggést, ami fennáll a $L_{m}$ és a $L_{z}$ között, és ez a következő egyenletnek adódott:

$$
L_{m} / \mathrm{cm}=(2,28 \pm 0,04)\left(L_{z} / \mathrm{cm}\right)^{1,33 \pm 0,02} .
$$

Azonos reakciókörülményeket alkalmazva a klorit-tetrationát és a jodát-arzénessav rendszerben - ami klorition és arzénessav felesleget, $25^{\circ} \mathrm{C}$-ot, illetve $3 \mathrm{~mm}$ vastag reakcióedényt jelent -, majd a meghatározott hatványkitevő értékeket összehasonlítva az mondható el, hogy ezek kísérleti hibán belül megegyeznek, hiszen a CT reakció esetében 1,31 \pm 0,08 [89], míg a IAA rendszernél ez az érték 1,33 \pm 0,02-nak adódott.

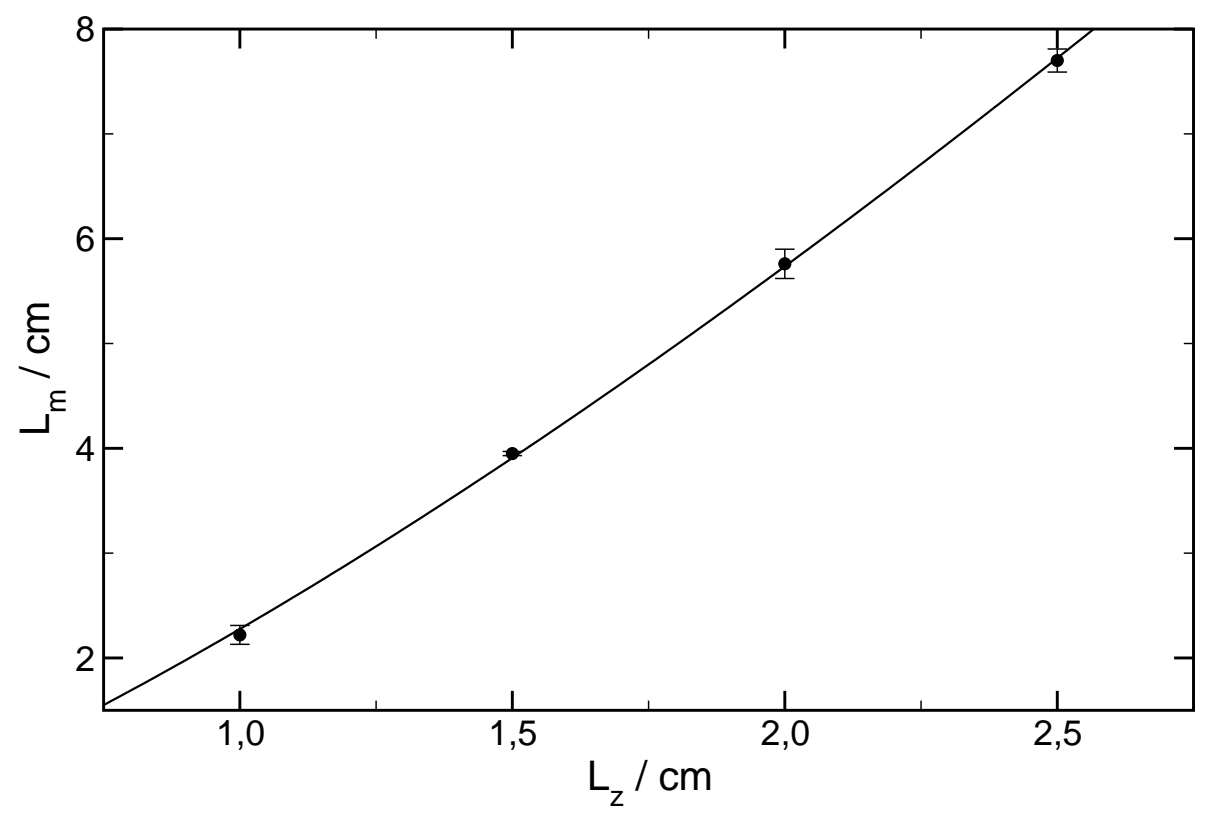

6.12. ábra. A keveredési hossz ábrázolása az edénymagasság függvényében $\mathrm{R}=3,9$ aránynál szobahőmérsékleten.

Mivel a jodátionok arzénessavval történő reakciója változik a sztöchiometriai aránytól függően, ezért lecsökkentettem a reaktánsarányt 2,8-ra, és megvizsgáltam itt is a kialakuló mintázatot. Ekkor a végtermék főleg a képződött jodidion és jód egyensúlyi reakciójában keletkező trijodidion. Ennél az összetételnél az arzénessav mennyisége kisebb, és ezért csökken a reaktánselegy súrúsége (lásd a 6.5. táblázatban). Ezen körülmények között kialakuló állandó alakú és sebességú aszimmetrikus mintázat a 6.13. ábrán látható. A létrejött alakzatok hasonlók, de az elnyúlás növekszik az edény magasságának növelésével. A meghatározott egyenlet $[\mathrm{As}(\mathrm{III})]_{0} /\left[\mathrm{IO}_{3}^{-}\right]_{0}=2,8$ arány esetében a következő: 


\section{(a)}

\section{(b)}

6.13. ábra. Az R $=2,8$ aránynál $1 \mathrm{~cm}\left(L_{m} / \mathrm{cm}=2,15 \pm 0,01\right.$ (a)) és $1,5 \mathrm{~cm}\left(L_{m} / \mathrm{cm}=3,81 \pm\right.$ 0,01 (b)) magas reakcióedénynél konstans alakkal bíró szobahőmérsékleten balról jobbra haladó reakciófrontokról készült képek.

$$
L_{m} / \mathrm{cm}=(2,2 \pm 0,1)\left(L_{z} / \mathrm{cm}\right)^{1,17 \pm 0,06} .
$$

A hatványfüggvény kitevője kisebb lett, ami jelezheti azt, hogy nem egy lépésben megy végbe az autokatalitikus folyamat. Az átmeneti termékek a reakciózónában halmozódnak fel. A hőhatás jelentőssé válik, ezért megnövekszik a sűrűségváltozás szobahőmérsékleten. Ezt a reakció $4{ }^{\circ} \mathrm{C}$-ra való hútésével hatékonyan ki lehet küszöbölni, ahogyan azt már korábban a CT rendszerben bemutatták lefele haladó reakciófront esetében [90]. A kialakult geometria ezen a hőmérsékleten is hasonló az előbbiekhez viszonyítva, de a keveredési hosszak kisebbek a kisebb sủrúségcsökkenés következtében, a csökkentett termikus hozzájárulás eredményeképpen. Analóg módon ezekben az esetekben is nő a $L_{m}$ az edény magasságával. A skálázási összefüggés a 6.14. ábra alapján adódik.

Az egyenlet $4{ }^{\circ} \mathrm{C}$-on $[\mathrm{As}(\mathrm{III})]_{0} /\left[\mathrm{IO}_{3}^{-}\right]_{0}=2,8$ aránynál pedig a következőképpen módo-

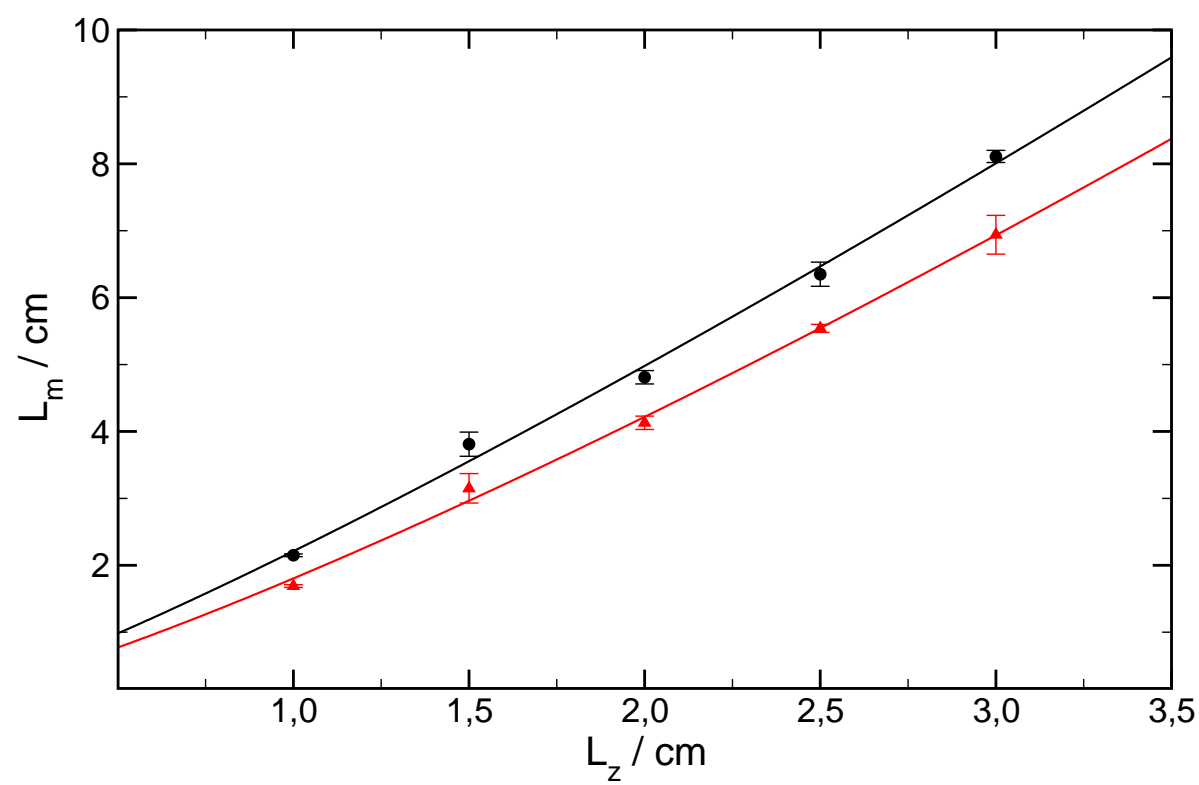

6.14. ábra. A keveredési hossz edénymagasságtól való függése $\mathrm{R}=2,8$ aránynál 25 illetve $4{ }^{\circ} \mathrm{C}$-on. 
sul:

$$
L_{m} / \mathrm{cm}=(1,80 \pm 0,08)\left(L_{z} /\right)^{1,23 \pm 0,05} .
$$

A két hőmérsékleten mért hatványkitevő értéke kísérleti hibán belül megegyezik. Ez összhangban van azzal a ténnyel, hogy nincs reakciómechanizmus változás a hőmérséklet csökkentésével adott reaktánsarány esetében. A kisebb sứrúségkülönbség hatására kisebbé vált a skálázási összefüggésben szereplő konstans értéke, hiszen ekkor a közegmozgás mértéke is lecsökken.

Megvizsgáltam a rendszert 2,6-os kezdeti koncentrációarány esetében is, ahol a jód menynyisége még tovább növekszik. Az arzénessav koncentrációjának további csökkentése a reaktánsoldat sû́rűségének még további csökkenését eredményezte. Megfelelő óvatossággal kell figyelembe venni a termékoldat sưrúségét a szilárd jód megjelenése miatt. Valószínúsíthetô, hogy a tényleges $\Delta \rho$ a reakciófront mellett kisebb, hiszen a kialakult alakzatok hossza sokkal kisebb, összehasonlítva a 6.15. és a 6.13. ábrákat. Ennél az összetételnél a kez-

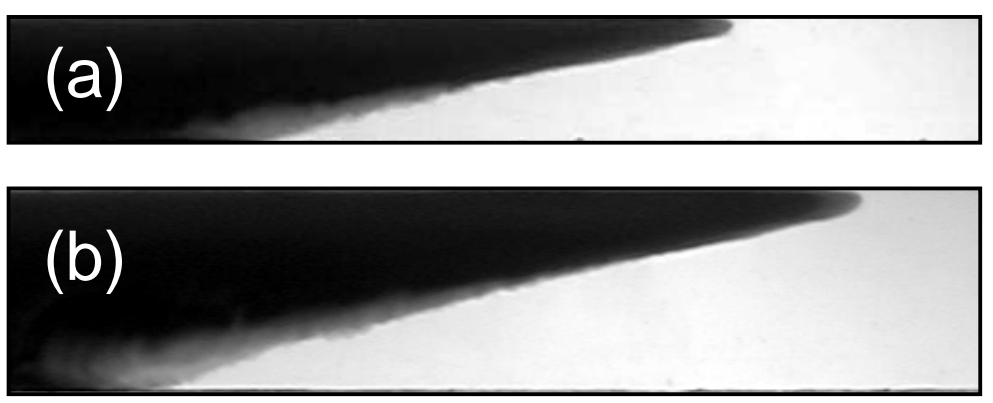

6.15. ábra. Az $\mathrm{R}=2$,6-nál konstans alakkal bíró balról jobbra haladó reakciófrontokról készült fényképek szobahômérsékleten: $1,5 \mathrm{~cm}\left(L_{m} / \mathrm{cm}=1,92 \pm 0,02\right.$ (a)) és 2,5 cm magas $\left(L_{m} / \mathrm{cm}=2,67 \pm 0,06(\mathrm{~b})\right)$ reakcióedény esetében.

deti vékony reakciófront vastagsága megnőtt, ezért itt már nem valósul meg a vékonyfrontközelítés. Ezt az indikátor színében bekövetkező árnyalatváltozás támasztja alá. Ebben az esetben a következő összefüggés áll fenn szobahőmérsékleten:

$$
L_{m} / \mathrm{cm}=(1,39 \pm 0,09)\left(L_{z} / \mathrm{cm}\right)^{0,78 \pm 0,06} .
$$

A kapott grafikon pedig a 6.16. ábrán látható. Ekkor a kitevő értéke kisebb egynél, és ez a reakciófront kiszélesedése miatt enyhén visszafele hajló görbét eredményez.

A különböző esetekben meghatározott frontok terjedési sebességét a 6.6. táblázatban adtam meg. Jelentôs különbséget nem lehet megfigyelni a frontsebességek értékei között az $R$ arány változtatása mellett. Korábbi kutatások során azt tapasztalták [91], hogy a frontok sebessége arányos volt a $L_{m} / L_{z}$ hányadossal, ami nálunk a (6.1) egyenlet alapján várhatóan $v \propto L_{z}^{0,33}$ alakúnak adódik. Az eredményünk megegyezik az általuk jósolt 0,36 $\pm 0,05$ érték- 


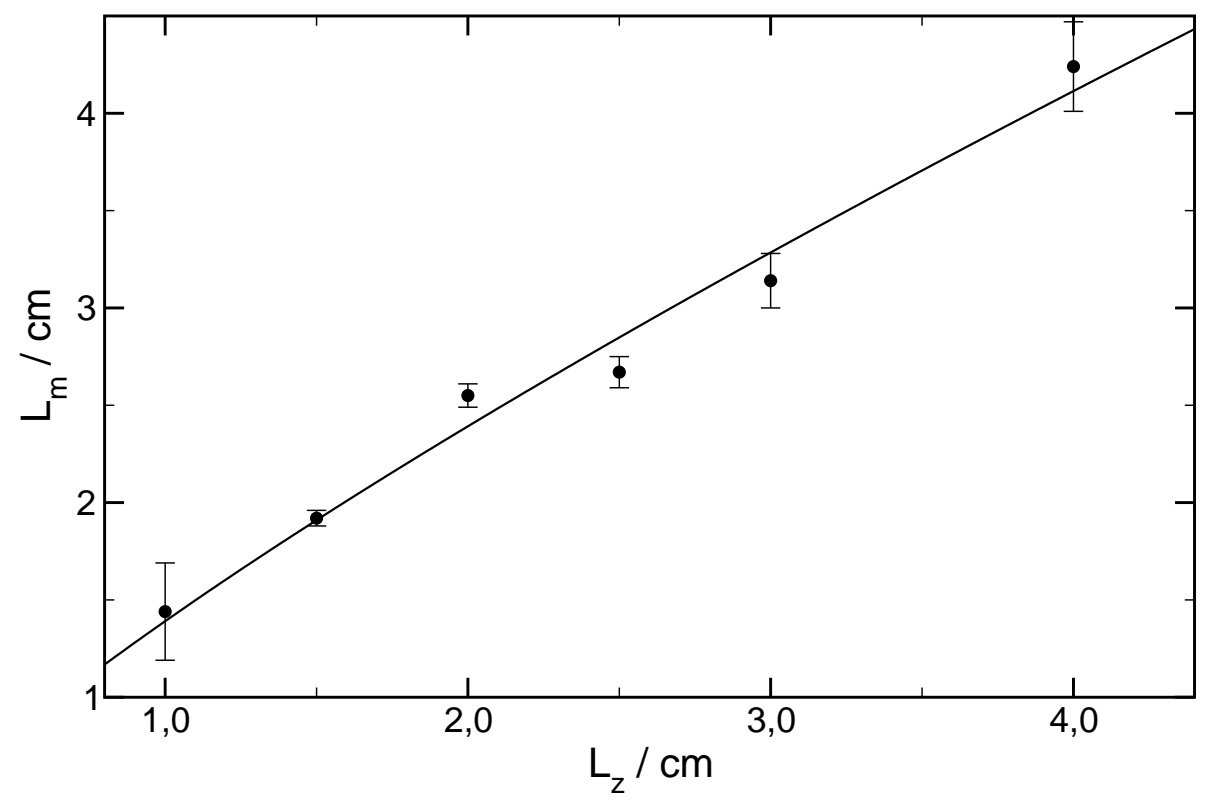

6.16. ábra. A keveredési hossz változása az edénymagasság függvényében $R=2,6$ aránynál szobahőmérsékleten.

kel [92].

A klorit-tetrationát reakcióra már korábban meghatározták az érvényes skálázási törvényt zárt rendszer esetén függőleges edényben vízszintesen terjedô vékony reakciófrontoknál [89]. A célom ennek az általánosítása volt, ezért ezt az összefüggést egy másik, a IAA rendszerben is megvizsgáltam. Megállapítható volt, hogy minden esetben kialakult egy időben állandó frontalak. Azt tapasztaltam, hogy a keveredési hossz az elméleti számítások eredményétôl eltérôen nem négyzetes arányosság szerint változott az edény magasságával, valamint, hogy a hatványkitevő értéke függött a reaktánsok, az arzénessav és a jodátionok kezdeti koncentrációarányától, hiszen ennek a csökkenésével a kitevő értéke is csökkent. A reakció során a hômérsékletet $25{ }^{\circ} \mathrm{C}$-ról $4{ }^{\circ} \mathrm{C}$-ra csökkentettem le, ami a kialakult szerkezet hosszának, vagyis a keveredési hossznak a csökkenését eredményezte, de a skálázási törvényben szereplő hatványkitevő értékét nem befolyásolta. A kisebb sưrûségkülönbség

6.6. táblázat. Frontsebességek $\mathrm{mm} \mathrm{s}^{-1}$ egységben megadva $25^{\circ} \mathrm{C}$-on.

\begin{tabular}{||c||c|c|c|c||}
\hline \hline \multirow{2}{*}{$\mathrm{R}$} & \multicolumn{4}{c||}{ Edény magassága $\left(L_{z} / \mathrm{cm}\right)$} \\
\cline { 2 - 5 } & 1 & 1,5 & 2 & 2,5 \\
\hline \hline 3,9 & $0,31 \pm 0,02$ & $0,35 \pm 0,01$ & $0,38 \pm 0,02$ & $0,44 \pm 0,01$ \\
\hline 2,8 & $0,29 \pm 0,01$ & $0,35 \pm 0,04$ & $0,36 \pm 0,01$ & $0,39 \pm 0,02$ \\
\hline 2,6 & $0,28 \pm 0,02$ & $0,38 \pm 0,01$ & $0,39 \pm 0,01$ & $0,49 \pm 0,01$ \\
\hline \hline
\end{tabular}


hatására kisebb lett a skálázási összefüggésben szereplő konstans értéke is. Az eredmények azt mutatták, hogy létezik egy univerzális skálázási kitevő $(1,32 \pm 0,08)$, ami a keveredési hossz és a centiméteres nagyságrendû edény magassága között áll fenn, továbbá az is elmondható, hogy ennek az értéke független a vékony folyadékrétegben végrehajtott kísérletek során fellépő sűrúségváltozás előjelétôl [92]. Térgeometriai megfontolások figyelembevételével hasonló következtetésre jutottak külföldi kutatók is, akik mind az elmélet, mind pedig kísérlet oldaláról megvizsgálták a közegmozgás hatását. Megállapították, hogy a folyadék magasságától függő keveredési hosszt nagyban befolyásolják a reakciókörülmények, és így mind a négyzetes arányosság, mind az 1,32-es hatványkitevő is érvényes lesz, csak más-más körülmények alkalmazása esetén [91,93,94].

\subsubsection{Háromdimenziós szerkezet tanulmányozása}

Eddig elegendően hosszú és keskeny reakcióedényben állandó sebességgel terjedő állandó alakzatok alakultak ki, amelyeket különböző kísérleti körülmények között tanulmányoztam. Csoportunkban azonban polielektrolit hozzáadásával oszcilláló mintázatot is sikerült már korábban kimutatni [76]. A jelenség kialakulásának oka nem volt ez idáig egyértelmú, ebből adódóan polielektrolit nélküli rendszerben, szélesebb edényekben szerettem volna megvizsgálni a klorit- és a tetrationátion közti reakciót. A harmadik dimenzió kiszélesítésének a hatását vizsgáltam meg ezen modellreakcióban végbemenő önszerveződésre. A már korábban alkalmazott $\left[\mathrm{NaClO}_{2}\right]_{0} /\left[\mathrm{K}_{2} \mathrm{~S}_{4} \mathrm{O}_{6}\right]_{0}=4$ aránynál dolgoztam, viszont a nátrium-hidroxid koncentrációt megnöveltem a reakció hosszabb ideig való eltarthatósága miatt (lásd a 6.7. táblázatban). Az egyes kísérletekhez jelentősebb oldattérfogatokat kellett bemérnem, ami több idôt vett igénybe, így tovább kellett elállnia a reakciónak anélkül, hogy magától beindult volna, és ehhez járult hozzá a nagyobb mennyiségú lúgoldat használata. Az eddig alkalmazott brómfenolkék indikátor koncentrációját lecsökkentettem a felére, mivel már vastagabb oldatrétegekben dolgoztam, és a kiértékelés során a kellő színerôsséghez ez is elegendônek bizonyult. A reakcióközegben szobahőmérsékleten mért sûrúség adatok a következők voltak: $\rho_{r}=0,9998 \mathrm{~g} \mathrm{~cm}^{-3}, \rho_{t}=1,0001 \mathrm{~g} \mathrm{~cm}^{-3}$.

6.7. táblázat. A reaktánselegy összetétele a CT rendszerben a harmadik dimenzió figyelembevételénél.

\begin{tabular}{||l|c||}
\hline \hline$\left[\mathrm{K}_{2} \mathrm{~S}_{4} \mathrm{O}_{6}\right]_{0} / \mathrm{mM}$ & 5,00 \\
{$\left[\mathrm{NaClO}_{2}\right]_{0} / \mathrm{mM}$} & 20,00 \\
\hline$[\mathrm{NaOH}]_{0} / \mathrm{mM}$ & 5,00 \\
\hline Brómfenolkék $]_{0} / \mathrm{mM}$ & 0,08 \\
\hline \hline
\end{tabular}


Új reakcióedényeket kellett terveznem, a feladat végrehajtásához. Először egy $12 \mathrm{~cm} \times 20 \mathrm{~cm}$-es cellában tanulmányoztam a kialakuló mintázatot, amelynek a magasságát 1 és $10 \mathrm{~mm}$ között változtattam. Egy ilyen elrendezés esetén megvalósított kísérlet képe látható a 6.17. ábrán. Nem sikerült polielektrolit hozzáadása nélkül oszcilláló mintázatot létrehoznom ilyen módon, viszont igen érdekes cellás szerkezetek jöttek létre. A 6.17. (a) és (b) ábrát megfigyelve szembetúnik, hogy állandó alakzatok nem jönnek létre, mivel 40 másodperc eltelte után több cella tapasztalható a képen. Ezeket a mintázatokat további vizsgálatnak vetettem alá úgy, hogy egyszerre oldalról és felülrôl is nyomon követhessem óket. Ehhez egy újabb edényt alkalmaztam, amit már a 4.5. ábrán bemutattam. Ezeknél a kísérleteknél az oldatréteg mindig $11 \mathrm{~mm}$ magas volt, és a küvetta szélességét változtattam $(6,11,16,21 \mathrm{~mm})$.

A nagy oldattömegnek köszönhetően igen jelentős a hőfejlődés a front mentén, amit nem képes a környezet elvezetni, ezért itt a CT rendszerben a hőmérséklet-változás okozta lokális sûrúségváltozás lesz a domináns, amelynek hatására a reaktánsoldat alá csúszik a termékoldatnak. Ezt már korábban is tapasztalták, de akkor $3 \mathrm{~mm}$ vastag és $4 \mathrm{~cm}$ magas távtartó alkalmazásával nem tudtak létrehozni konstans frontalakokat [89]. A 6.18. ábrán 6 mm széles küvettában elvégzett kísérletről láthatunk felvételeket, ahol szintén nem alakul ki állandó alakzat, hiszen a felülnézeti képeket 1 perc elteltével szemügyre véve nem egyeznek meg az alakok. Itt a hőfelszabadulás és az edény falán keresztül történő hőleadás összemérhetôn nagy-

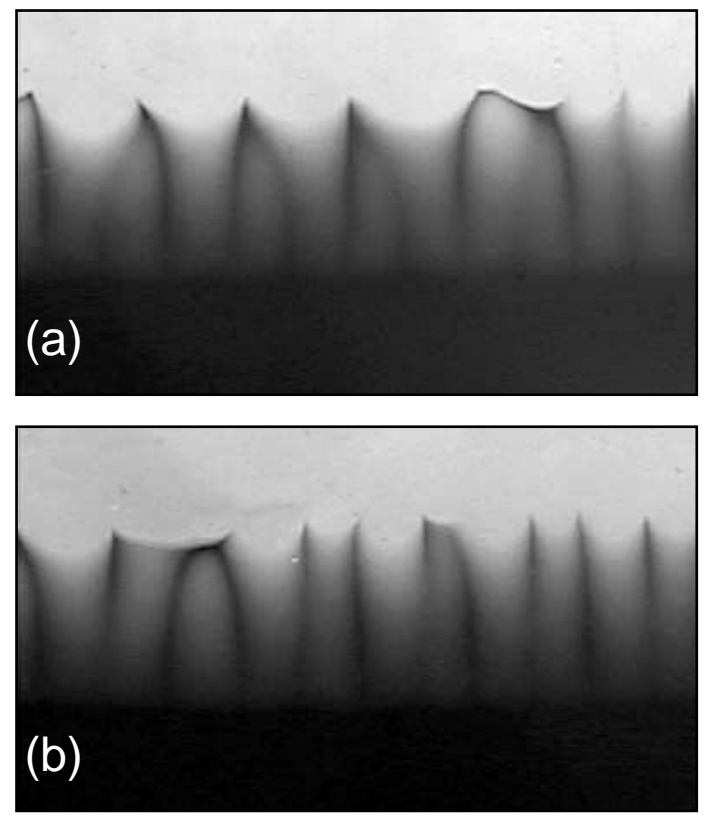

6.17. ábra. Vízszintesen haladó cellás szerkezetekrôl készült képek $5 \mathrm{~mm}$ magasságú cellában, az indítástól számított 244 s (a) és 284 s (b) elteltével. A világos rész a termék-, míg a sötét részek a reaktánselegynek felelnek meg. 


\section{(a)}

(b)

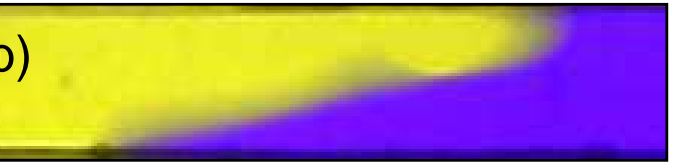

(c)

(d)

6.18. ábra. Egy 6 mm széles küvettában balról jobbra haladó frontokról $30 \mathrm{~s}$ (a)-(b) és $90 \mathrm{~s}$ (c)-(d) után készült fényképek. Oldal- (b)-(d) és felülnézetből (a)-(c).

ságúvá vált, és ez állandóan változó mintázatot eredményezett. Mivel nem sikerült állandó alakzatokat létrehozni a legkisebb térfogatú reakcióedény esetében, így azokat a kísérleteket, amiket abban hajtottam végre mennyiségileg nem is tudtam kiértékelni.

Megfelelően vastag üvegfalú reakcióedények szélességét növelve már 11 mm oldatvastagság esetében időben állandó, valamint állandó sebességgel haladó cellás szerkezetek alakultak ki egy átmeneti periódus után. Ezek láthatók a 6.19. ábrán. Feltételezhetôen az exoterm reakció során végbemenő hôtermelődés az, ami segít a mintázat stabilizálódásában. Elmondható, hogy kellően vékony és nagyon vastag oldatrétegekben lehetséges állandó sebességgel terjedő állandó alakzatokat létrehozni a kísérleti tapasztalatok alapján. A keskeny folyadékrétegek esetében az edényfalán át történő hőleadás válik dominánssá, míg a folyadék vastagságát növelve a hőhatás már annyira nagymértékú lesz, hogy a falon keresztül, a hőmérséklet csökkentése céljából véghezvitt hútés hatásfoka nem lesz megfelelő mértékú.

Az időben állandó mintázatra jellemző átlagos frontalakokat meghatároztam. Az oldalnézetből figyelemmel kísérhető alakok teljesen megegyeztek (lásd a 6.20. ábrán). A fényképeket elnézve feltúnik némi különbség a 6.19. ábrán az oldalsó alakzatok között, de a kiértékelésnél a front azon részét jellemeztem csak - a rendelkezésemre álló kiértékelő program segítségével -, ahol az indikátor kék színe már egyértelmúen átváltozott. Az itt kialakult mintázatok egységesnek bizonyultak, és a továbbiakban erre a frontrészletre elülső részeként fogok hivatkozni, míg a hátulsó frontalak azt reprezentálja, mikor az indikátor teljesen

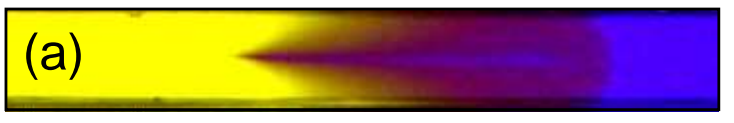

(b)

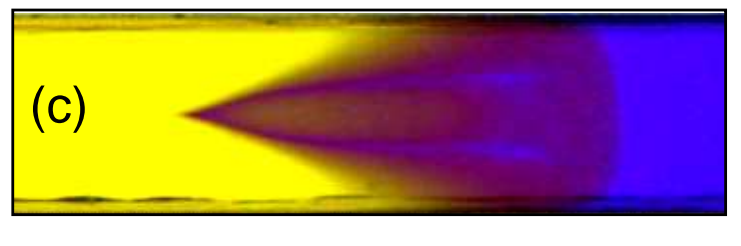

(d)

6.19. ábra. Balról jobbra haladó frontok oldal- (b)-(d) és felülnézeti (a)-(c) képei 100 másodperc után 11 (a)-(b) és 21 mm (c)-(d) széles küvettában elvégzett kísérletek esetén. 


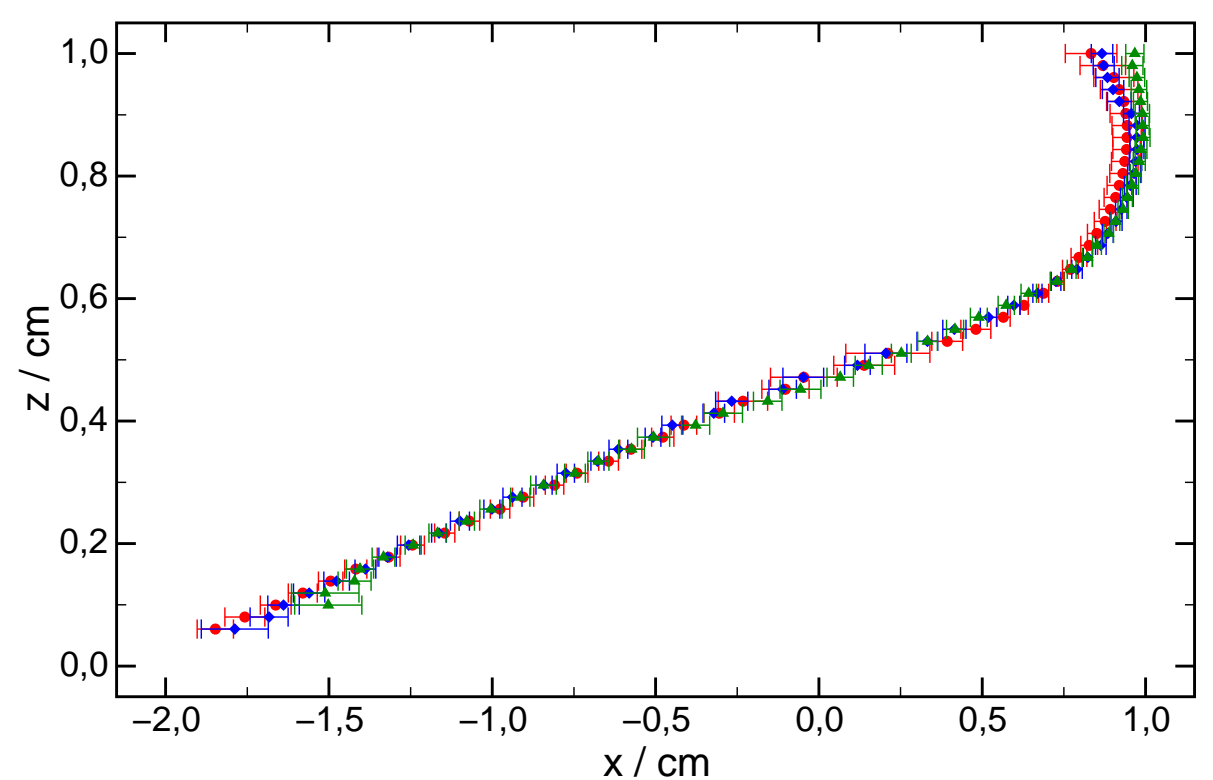

6.20. ábra. Az időben állandó mintázatra jellemző átlagos frontalakok oldalnézet esetében: $11 \mathrm{~mm}(\bullet), 16 \mathrm{~mm}(\diamond), 21 \mathrm{~mm}(\boldsymbol{\Delta})$ széles üvegküvettánál. A reakciófront balról jobbra haladt.

sárgaszínúvé vált.

A felülnézetből látható alakzatok elülsô és hátulsó részét is megvizsgáltam. A színes képeket komponenseire bontottam fel egy csoportunkban készített programmal. A 6.21. ábra a front legelején kialakult mintázatot - ahol még nem ment végbe teljesen a reakció a

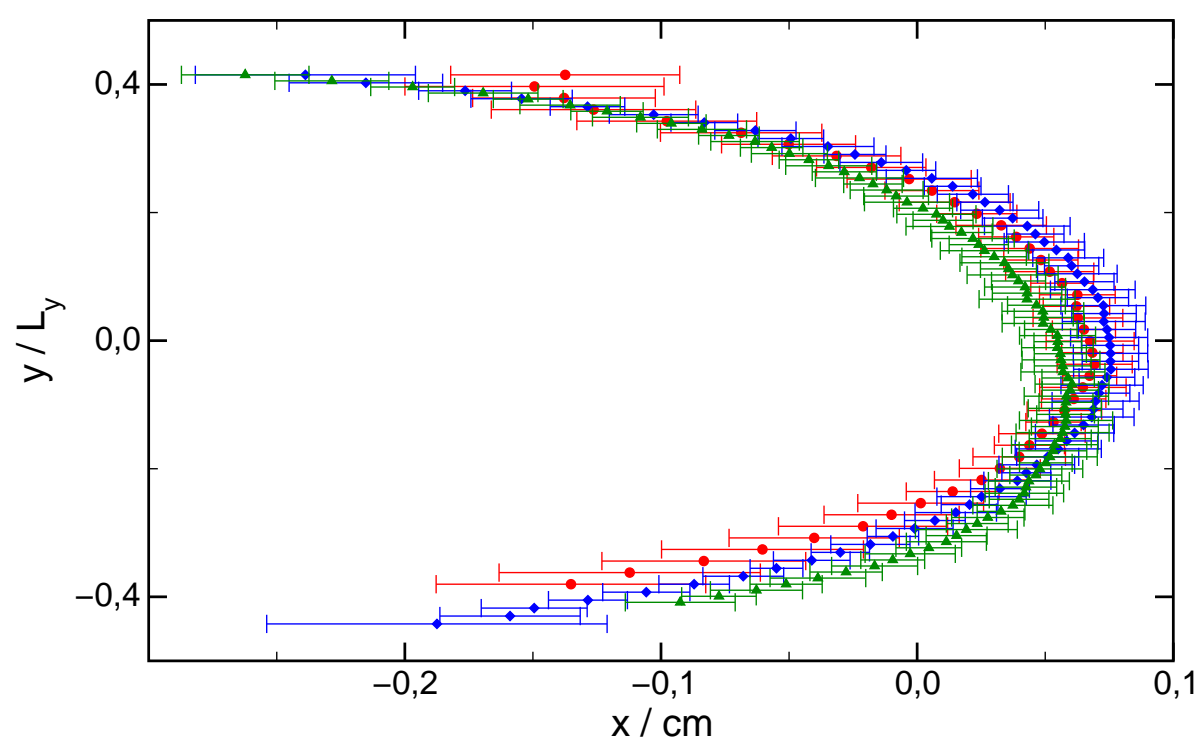

6.21. ábra. Felülnézet esetén az idôben állandó mintázatok elülsô részének az átlagos frontalakjai: $11 \mathrm{~mm}(\bullet), 16 \mathrm{~mm}(\diamond), 21 \mathrm{~mm}(\boldsymbol{\Delta})$ széles üvegküvetta esetében. 
rendelkezésre álló reakciótér egészében - mutatja be. A kvantitatív jellemzéshez az átlagos frontalakzatokat a megfelelő edényszélességekkel elosztva az ún. normalizált frontalakokhoz jutottam, és ezeket ábrázoltam. Az látszik az ábrából, hogy az alakok jó átfedést mutattak.

Felülnézetből az alakzatok hátulsó részén, ahol már teljesen lejátszódott a reakció, ott egy fektetett $\mathrm{V}$ formájú és $\sim 34$ fokos szöget bezáró mintázatok alakult ki, amik a 6.22. ábrán figyelhetők meg. Ezekben az esetekben nem hajtottam végre az y-tengely menti skálázást, hiszen így is szembetûnô az eredeti alakok nagyfokú azonossága. A rendelkezésre álló térnek megfelelően különböző nagyságú, de azonos nyílási szögú $\mathrm{V}$ formájú minták keletkeztek a reakció lejátszódása során. Hasonló mintázatok létrejöttét tapasztalták más kutatók is, akik szintén a háromdimenziós hullám vízszintes terjedését vizsgálták, de a jodát-arzénessav rendszerben az oldatréteg magasságának változtatásával [95].

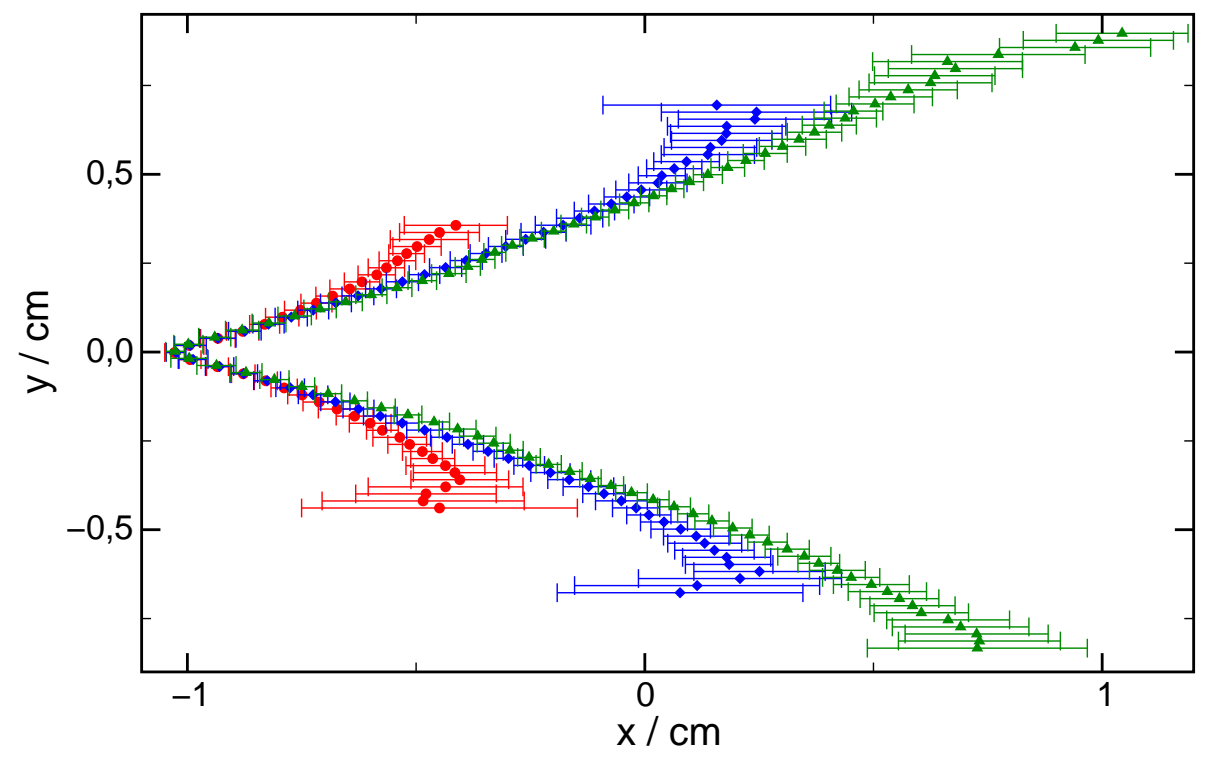

6.22. ábra. Felülnézetből az időben állandó hátulsó mintázatra jellemző átlagos frontalakok: $11 \mathrm{~mm}(\bullet), 16$ mm (\), $21 \mathrm{~mm}(\boldsymbol{\Delta})$ széles üvegküvettánál.

A növekvő cellaszélességnél kapott frontsebességek értékeit összehasonlítva az látható, hogy nem térnek el jelentős mértékben egymástól, közel azonosnak mondhatók. Az oldalnézeti frontprofilokból számolt reakciófrontok terjedési sebességét tüntettem fel a 6.8. táblázatban, mert ott a kiértékelés során kapott sebességek egy nagyságrenddel pontosabbnak

6.8. táblázat. Frontsebességek a háromdimenziós mintázatoknál a CT reakcióban.

\begin{tabular}{||c||c|c|c||}
\hline \hline Cellaszélesség $\left(L_{y} / \mathrm{mm}\right)$ & 11 & 16 & 21 \\
\hline $\mathrm{v}\left(\mathrm{mm} \mathrm{s}^{-1}\right)$ & $1,08 \pm 0,01$ & $1,05 \pm 0,01$ & $1,06 \pm 0,01$ \\
\hline \hline
\end{tabular}


adódtak, és hibán belül megegyeztek a felülnézetből kalkulált értékekkel. A 6 mm széles edény esetén is végeztem egy becslést, és ott a $v=0,91 \pm 0,01 \mathrm{~mm} \mathrm{~s}^{-1}$ volt. A reakcióban bekövetkező hőmérsékletváltozás $2,3{ }^{\circ} \mathrm{C}$ volt a termoelemes mérés alapján a $21 \mathrm{~mm}$ vastagságú küvettában.

A kísérletekből megállapítható, hogy polielektrolit hozzáadása szükséges az oszcilláló mintázatok kialakításához a CT rendszerben. A harmadik dimenzió kiszélesítése újból állandó alakzatok keletkezését eredményezi, de ennek van egy minimum értéke. Az általam alkalmazott reakciókörülmények között a minimum oldatvastagság $11 \mathrm{~mm}$-nek adódott. Ez alatt a vastagság alatt, folyamatosan mozgásban lévő mintázat kialakulása volt megfigyelhető. A mintázatképződés egységes volt, hiszen az alakok jó átfedést mutattak, és csak a hosszúságukban volt eltérés az adott folyadékvastagságtól kezdődően. A kiértékelés során tapasztaltak alapján elmondható, hogy a reakció előrehaladtával kialakuló, az időben állandó alakkal és sebességgel jellemezhetô felülnézeti és oldalnézeti stabil mintázatok mennyiségi jellemzője független az oldatvastagságtól egy meghatározott edényszélesség felett.

\subsection{Marangoni instabilitás kísérleti megvalósítása}

\subsubsection{A klorit-tetrationát reakció esetén kapott eredmények}

A Marangoni instabilitást először a klorit- és a tetrationátion között lejátszódó autokatalitikus reakcióban szerettem volna kimutatni. Ebben a fejezetben az erre irányuló kísérleti munkám során kapott eredményeim kerülnek bemutatásra.

A dimenziómentes Marangoni szám - aminek az értéke az instabilitás mértékét, az előjele pedig az irányát adja meg - a következőképpen adható meg [46]:

$$
M=-\frac{1}{\eta \sqrt{D k}} \frac{\mathrm{d} \gamma}{\mathrm{d} c} \approx-\frac{1}{\eta v} \Delta \gamma
$$

mivel a reakciófront $v$ sebessége arányos lesz a $D$ diffúziós koefficiens és a $k$ sebességi együttható szorzatának négyzetgyökével Luther nyomán [96]. A Marangoni szám pozitív, ha a reakciófront mögött csökken a termék felületi feszültsége, ha pedig nő, akkor $M<0$. Híg vizes oldatokban dolgoztam, ezért a ๆ-t a víz viszkozitásának értékével közelítettem [97].

Kétféle kiindulási koncentráció mellett dolgoztam, amelyeket a 6.9. táblázatban foglaltam össze. Először megalkottam a kísérletekhez szükséges cellát, aminek az egyik nagy előnye, hogy könnyú megtölteni a reakcióteret a reaktánsoldattal, és kellőképpen sík felszínt biztosít a reakcióhoz.

Tenzid hozzáadásával kívántam módosítani az alapesetben fennálló felületi feszültség viszonyokat, ugyanis ezek olyan felületaktív anyagok, amelyek a határfelület mentén való 
6.9. táblázat. A reaktánselegy összetétele a klorit-tetrationát rendszerben.

\begin{tabular}{||l||c|c||}
\hline \hline & $\ddot{\mathrm{O}}_{1}$ & $\ddot{\mathrm{O}}_{2}$ \\
\hline \hline$\left[\mathrm{K}_{2} \mathrm{~S}_{4} \mathrm{O}_{6}\right]_{0} / \mathrm{mM}$ & 5,00 & 2,50 \\
\hline$\left[\mathrm{NaClO}_{2}\right]_{0} / \mathrm{mM}$ & 20,00 & 10,00 \\
\hline$[\mathrm{NaOH}]_{0} / \mathrm{mM}$ & 1,97 & 1,97 \\
\hline$[\mathrm{Na}-\mathrm{sztearát}]_{0} / \mathrm{mM}$ & 0,32 & 0,32 \\
\hline$[\text { Brómfenolkék }]_{0} / \mathrm{mM}$ & 0,08 & 0,08 \\
\hline \hline
\end{tabular}

feldúsulásukkal befolyásolják a folyadék felületi feszültségét. Alkalmazásra került mind anionos - nátrium-sztearát (Reanal), nátrium-lauril-szulfát (Spektrum 3D) -, mind pedig kationos - oktadecil-amin (Aldrich) - tenzid is. Azt vártam, hogy az anionos tenzid adagolásának eredményeképpen a reaktánsoldat felületi feszültsége lecsökken a termékéhez képest $\left(\gamma_{t}>\gamma_{r}\right)$, és így egy elnyúltabb front alak kialakulása lesz tapasztalható az oldat feletti légréteg megjelenése esetén, a szabad felszín nélküli kísérletekhez képest. Ezt a 2.5. (a) ábra kívánja szemléltetni. A kationos tenzid hatására pedig a 2.5. (b) ábrán illusztrált, kevésbé elnyúlt reakciófrontok kialakulására számítottam a létrejövő $\gamma_{t}<\gamma_{r}$ reláció miatt. Ezen kísérleti munka során használt reakcióedény már korábban a 4.4. ábrán bemutatásra került.

Az oktadecil-amin alkalmazása nem volt sikeres, mert a termékelegyben a reakció lejátszódása során csapadékkiválás volt tapasztalható. Ez nem előnyös, mivel befolyásolja a mintázatképződést, valamint a kellő pontosságú kiértékelést elvégzését is akadályozza. Éppen ezért a továbbiakban nem folytattam az ez irányú kísérleteket. Áttértem az anionos tenzidek hatásának tanulmányozására, azok közül is először a nátrium-sztearátéra. A kísérletek során kiderült, hogy a hőmérséklet egy nagyon fontos tényező ebben az igen exoterm reakcióban. Egyrészről abból a szempontból, hogy a kiértékeléshez állandó alakzat szuikséges, ami magasabb hômérsékleten nem alakul ki az általam alkalmazott elrendezés esetén; másrészról pedig a reakcióteret termosztálni kell ahhoz, hogy reprodukálhatóak legyenek a kísérletek, mivel vastag oldatrétegeknél dolgoztam. Mindezek már a reakció $15^{\circ} \mathrm{C}$-ra történő lehútésekor megvalósulnak.

A munkám során még tovább csökkentettem a hőmérsékletet egy termosztát segítségével, ugyanis szerettem volna megnézni azt is, hogy az exoterm reakció során fellépő hőmérsékletnövekedés okozta sưrúségváltozásnak a kiküszöbölése, milyen hatással van a kialakuló mintázatra. Ennek érdekében a reaktánsoldatot $4{ }^{\circ} \mathrm{C}$-ra termosztáltam, hiszen a víz sûrúségének hômérséklet-függését vizsgálva a görbének $4{ }^{\circ} \mathrm{C}$-nál van maximuma, amint az a 6.23. ábrán is jól látszódik. Elmondható, hogy a maximum környékén a víz sưrüsége függetlennek tekinthetô a hőmérséklettől, és mivel híg vizes oldatokban hajtottam végre a kísérleteket, ez az összefüggés érvényes lesz az alkalmazott rendszerre is. A J-típusú Fe-CuNi termoelem segít- 


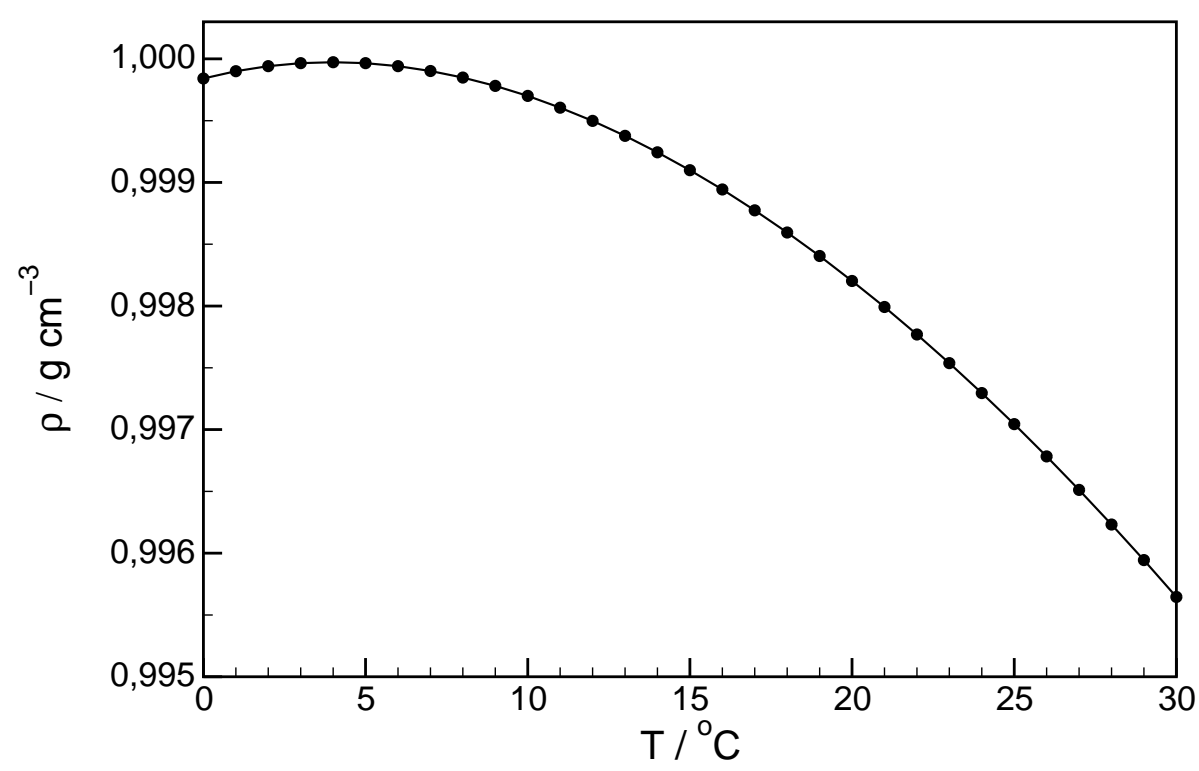

6.23. ábra. A víz sûrűségének változása a hőmérséklet függvényében.

ségével megmértem az egyes távtartók esetében, hogy mennyire kell a reakcióteret lehúteni ahhoz, hogy a reakció során fejlődő hő (kb. $1-2{ }^{\circ} \mathrm{C}$ ) hatására is még mindig a görbe maximum pontjának a környékén legyen a rendszer. Ekkor ugyanis igaz, hogy a hômérsékletnövekedés okozta sûrúségváltozás elhanyagolható a kémiai összetétel változásából adódó sûrúségváltozáshoz képest.

A 6.24. ábrán bemutatott egyes frontalakokról készült képek alapján elmondható, hogy a hőmérséklet csökkentésével egyre hosszabb, elnyúltabb alakzatokhoz jutunk. A hútéssel együtt a reakciók sebessége is csökkent.

Az volt a célom, hogy a tenzidoldat reaktánselegyhez való hozzáadása csak a folyadék/gáz határfelület mentén fejtse ki a hatását, vagyis hogy ne okozzon semmilyen változást akkor, amikor nincs légréteg a reakciótér felett. Éppen ezen okból kifolyólag zárt, valamint nyitott felszínnél is végrehajtottam a kísérleteket, megnézve azt, hogy az új anyag jelenlété-
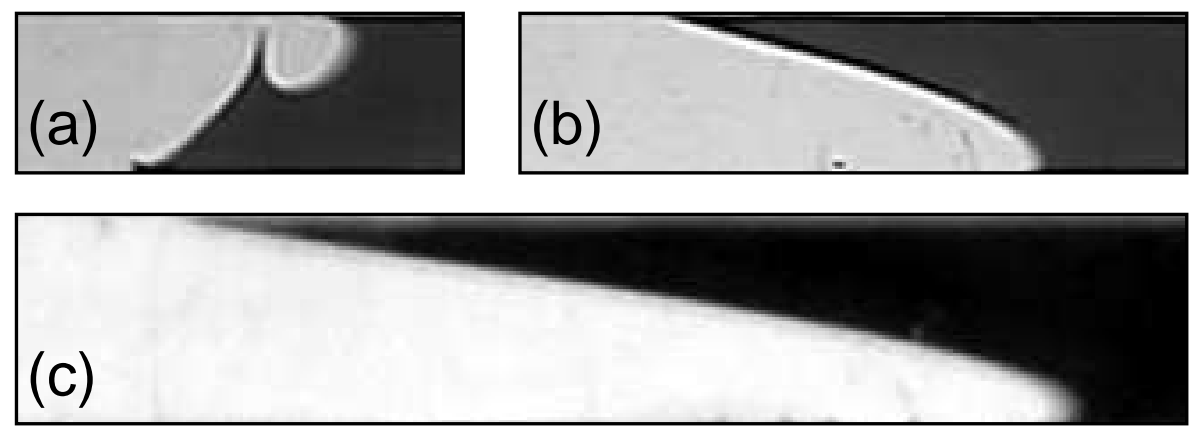

6.24. ábra. Balról jobbra haladó frontokról készült felvételek: $25^{\circ} \mathrm{C}$ (a), $15{ }^{\circ} \mathrm{C}$ (b), $4{ }^{\circ} \mathrm{C}$ (c). 
ben és nélküle mennyire egybeeső alakokat kapok. Elmondható a 6.25. ábra görbéi alapján, hogy a kívánt célt sikerült elérni, mivel az időben állandó mintázatra jellemző átlagos frontalakok jó átfedést mutattak, vagyis a tenzid hatása zárt rendszernél nem érvényesült. A keveredési hossz értékek szinte teljesen megegyeztek: $\overline{\mathrm{L}_{\mathrm{m}}}=1,37 \pm 0,06 \mathrm{~cm}$.

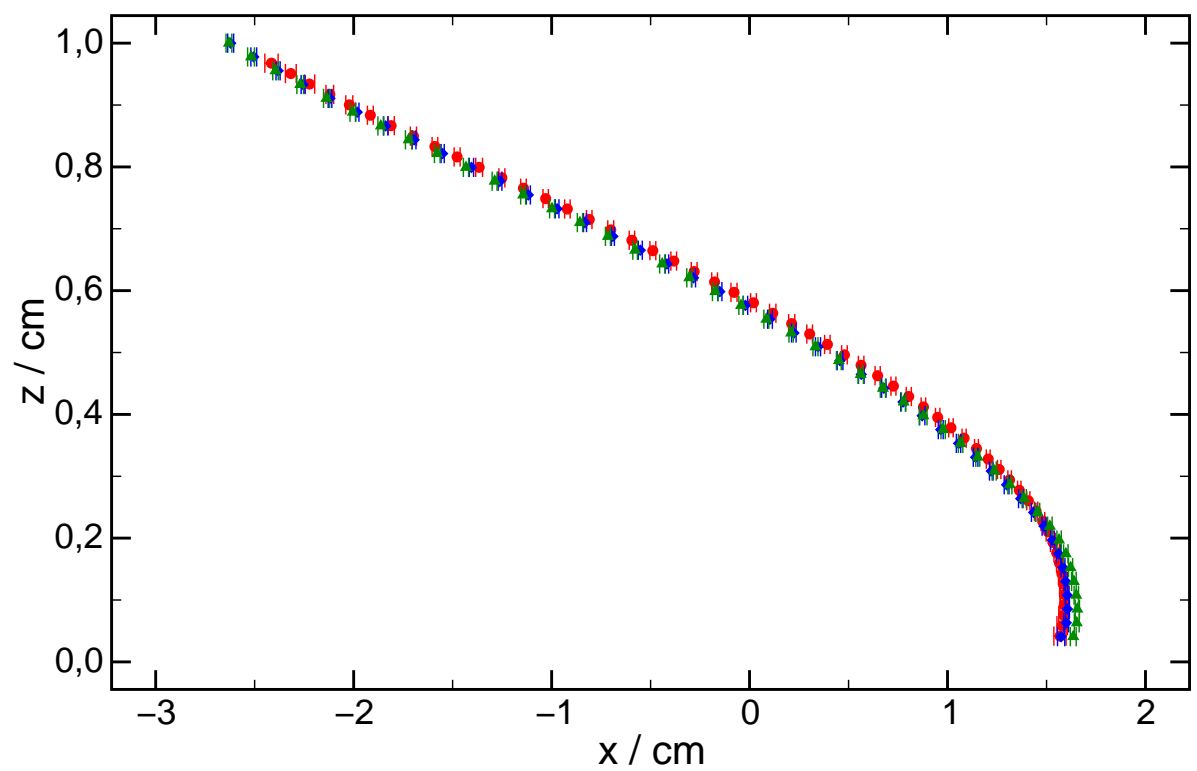

6.25. ábra. Az időben állandó mintázatra jellemző átlagos frontalakok $3 \mathrm{~mm}$ vastagságú távtartó esetében $4{ }^{\circ} \mathrm{C}$-on: nincs szabad felszín tenzid alkalmazásakor $(\bullet)$, nincs szabad felszín tenzid nélkül $(\checkmark), 1 \mathrm{~cm}$ légréteg esetében tenzid nélkül ( $\mathbf{\Delta})$.

A fellépő konvekció mértékének növelése érdekében az egyre vastagabb távtartókkal kezdtem dolgozni annak a reményében, hogy a nagyobb rendelkezésre álló terület hozzájárulhat a tanulmányozott jelenség kialakulásához. Ahogyan az a 6.26. ábrán látható, a 10 mm vastag távtartó esetében létrejött átlagos frontalakok összehasonlításakor a görbék teljesen jól illeszkedtek egymásra, vagyis nem lépett fel frontmódosulás a Marangoni instabilitás hatására. A keveredési hossz értékek is hibán belül megegyeztek.

A koncentráció változtatás hatását is megvizsgáltam, mert korábban a csoportunkban azt tapasztalták ezen reakció tanulmányozásakor, hogy igen meghatározó módosulást eredményez ez a mintázatban [98]. Így tértem át a 6.9. táblázatban feltüntetett $\mathrm{O}_{2}$ oszlopban lévő koncentrációkra, amik az eredeti koncentrációk felének feleltek meg. A kísérletekről készült képek alapján semmi különbség nem látszódott a kialakult mintázatok hosszában a kétféle felszínnél. Az alakok jobban elnyúltak, mint mikor az eredeti összetételt alkalmaztam, ugyanis megváltoztak a sûrúségviszonyok. A mennyiségi kiértékelés is ezt támasztotta alá, mivel a keveredési hossz értékek is megegyeztek a zárt és nyitott felszínek esetében.

Szemléltetés céljából még szeretném bemutatni, hogy a falvastagság növelés egyre hoszszabb reakciófrontokat eredményezett (lásd a 6.27. ábrán). A reakció során fellépő sűrúség- 


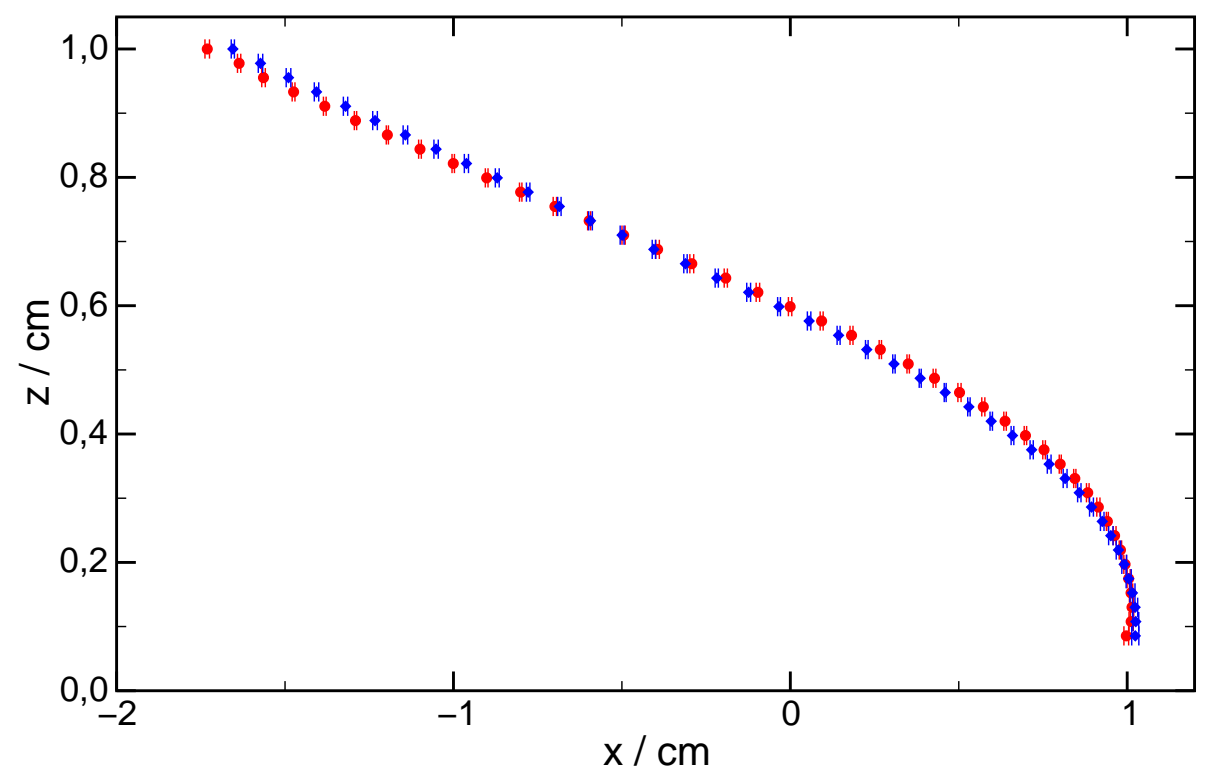

6.26. ábra. Az időben állandó mintázatra jellemző átlagos frontalakok $15{ }^{\circ} \mathrm{C}$-on: nincs szabad felszín $\left(\mathrm{L}_{\mathrm{m}}=0,89 \pm 0,02 \mathrm{~cm} \diamond\right), 2 \mathrm{~cm}$ légréteg $\left(\mathrm{L}_{\mathrm{m}}=0,92 \pm 0,02 \mathrm{~cm} \bullet\right)$.

változás miatt a nagyobb reakciótér nagyobb közegmozgás kialakulására ad lehetôséget, és ez okozza az elnyúltabb alakokat. Az is látszik, hogy egy idô után már a növekedés mértéke nem lesz olyan nagy, ahogy az a 6 és a 10 mm vastag távtartó esetében észlelhető.

Természetesen megmértem a reaktáns- és termékoldat felületi feszültség értékeit Páhi Barbara Annamária segítségével a Wilhelmy-lemez módszerrel 25 és $15^{\circ} \mathrm{C}$-on is. A kapott

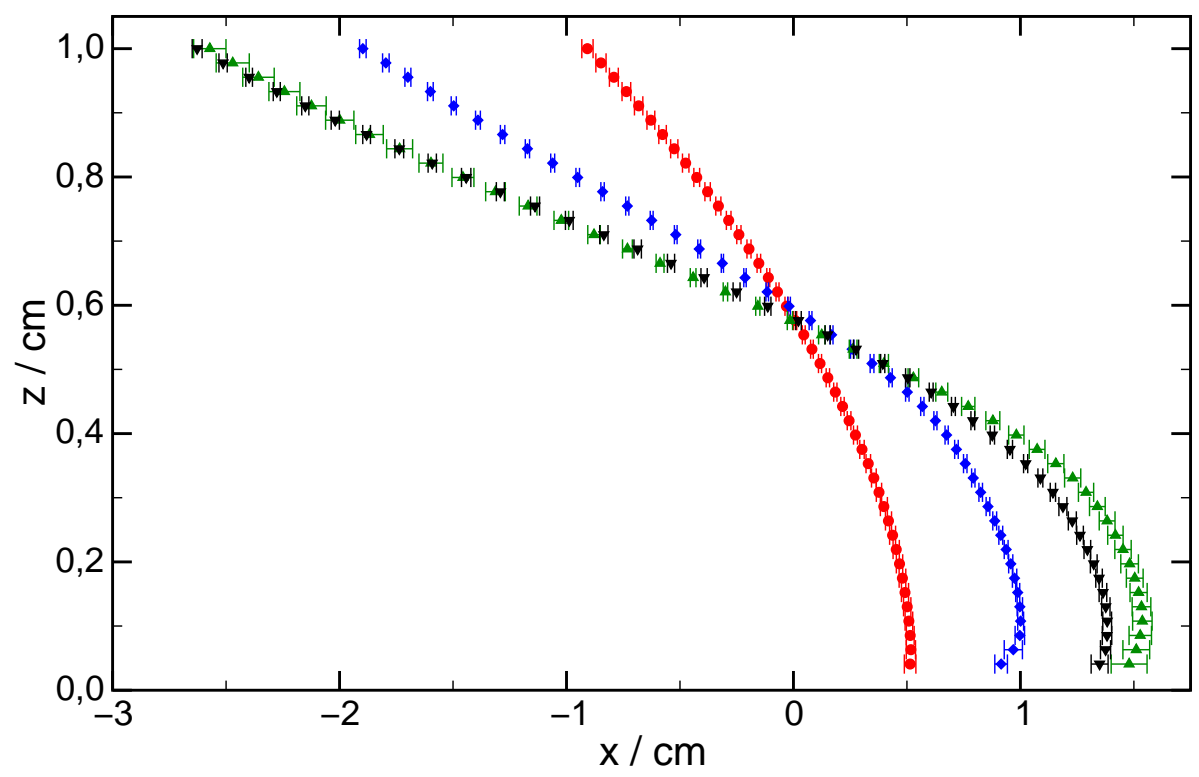

6.27. ábra. Az időben állandó mintázatra jellemző átlagos frontalakok $15^{\circ} \mathrm{C}$-on különböző vastagságú távtartóknál: $1 \mathrm{~mm}(\bullet), 3 \mathrm{~mm}(\diamond), 6 \mathrm{~mm}(\boldsymbol{\Delta}), 10 \mathrm{~mm}(\boldsymbol{\nabla})$. 
mérési adatokat a 6.10. táblázatban foglaltam össze. A termékoldat felületi feszültsége minden esetben nagyobb lett, mint a reaktánsoldaté, azonban úgy tûnik, hogy ez a pár $\mathrm{mN} \mathrm{m}^{-1}$ felületi feszültségváltozás nem elég a Marangoni instabilitás vizuális kimutatásához. A Marangoni számot $25^{\circ} \mathrm{C}$-on nem lehetett megbecsülni, mivel nem jött létre állandó sebességgel terjedő alakzat, viszont $15{ }^{\circ} \mathrm{C}$-on $\mathrm{O}_{1}$ összetétel esetében körülbelül -5000 lett. Feltehetően a Marangoni instabilitás ekkora nagyságrendû szám esetén még nem lép fel.

6.10. táblázat. A felületi feszültség mérés eredményei a CT rendszerben.

\begin{tabular}{||c||c|c||}
\hline \hline $\mathrm{O}_{1}$ & $\begin{array}{c}15^{\circ} \mathrm{C} \text {-on } \\
\gamma / \mathrm{mN} \mathrm{m}^{-1}\end{array}$ & $\begin{array}{c}25^{\circ} \mathrm{C} \text {-on } \\
\gamma / \mathrm{mN} \mathrm{m}^{-1}\end{array}$ \\
\hline \hline reaktáns & 49,8 & 45,3 \\
\hline termék & 51,5 & 50,0 \\
\hline$\Delta$ & 1,7 & 4,7 \\
\hline \hline
\end{tabular}

A nátrium-lauril-szulfáttal (SDS) történő kísérleteket László Balázs végezte el. A munkája során Ő sem tudta ezt a jelenséget egyértelmúen kimutatni. Sốt nála a reaktánsoldat általában zavarossá vált, valószínúleg azért, mert a tenzidet a kritikus micellaképződési koncentrációja közelében alkalmazta. Ebben az esetben a felületi feszültség értékek közti különbségek még kisebbeknek adódtak.

A CT rendszerben az általam alkalmazott reakciókörülmények között nem lehet kimutatni a Marangoni instabilitást, mivel a felületi feszültség viszonyok nem változnak a kellő mértékben. A kiindulási koncentráció változtatása, valamint a reakciótér vastagságának növelése sem tud megfelelően hozzájárulni a jelenség gravitációs erőtérben történő sikeres kimutatásához. Éppen ezért visszatértem a kezdetben tanulmányozott rendszerhez (jodátarzénessav), mivel ott már az idő elôrehaladtával magában a reakcióban képződik egy felületaktív anyag a megfelelő kísérleti körülmények között.

\subsubsection{Az instabilitás jodát-arzénessav reakcióban történó kimutatása}

Ebben a fejezetben már az arzénessav jodátionnal történő oxidációja során kívántam kísérletileg megvizsgálni a Marangoni instabilitást. Ezen modellreakció tanulmányozása a jelenség szempontjából azért is ígérkezett alkalmasabbnak, mint a korábbi, mivel a megfelelő $[\mathrm{As}(\mathrm{III})]_{0} /\left[\mathrm{IO}_{3}^{-}\right]_{0}$ aránynál végrehajtva a kísérleteket jód képződik, ami szintén egy felületaktív anyag. Az irodalmi áttekintésben leírtak alapján választottam ki a célnak megfelelő reaktánselegy összetételeket. Itt is kétféle kiindulási koncentrációt használtam, annak érdekében, hogy a reakció szempontjából fontos $[\mathrm{As}(\mathrm{III})]_{0} /\left[\mathrm{IO}_{3}^{-}\right]_{0} \approx 8 / 3$ arány két oldalán lévő tartományban is megnézhessem a határfelületi jelenség hatását. A 6.4. táblázat harmadik és 
negyedik oszlopában találhatóak az egyes arányoknak megfelelő kiindulási koncentrációk.

Ezek után a kapott kísérleti eredményeimet szeretném összefoglalni. Indikátorként ebben az esetben is a reakcióban képződött $\mathrm{I}_{2}, \mathrm{I}_{3}^{-}$színét alkalmaztam. Vagyis elmondható, hogy a reakció során termelődő jód két szempontból is nagyon fontos. Ebben a reakcióban a sưrúségviszonyok pont fordítottak, mint az előbbi klorit-tetrationát reakciónál, azaz a reaktáns sûrüsége nagyobb a termék sứrúségénél. A vízszintesen haladó függőleges reakciófront itt is megdôl, de éppen az ellenkező irányba. Hiszen a kisebb sû́rúségú termékoldat a közegmozgás eredményeképpen a reaktánsoldat fölé csúszik, ahogyan az a 6.28. (a) ábrán is látszódik, amikor $\gamma_{t}=\gamma_{r}$. A felületaktív jód képződése csökkenti a termék felületi feszültségét $\left(\gamma_{t}<\gamma_{r}\right)$, ezért azt vártam, hogy a hatása úgy fog jelentkezni, hogy a kialakult alakzatok elnyúltabbá, hosszabbá válnak. Ezt szemlélteti a 6.28. (b) ábra. Reméltem, hogy csak a nyitott felszínnél eredményez frontalak módosulást a jód, és nem befolyásolja a teljes frontot, hiszen a Marangoni instabilitás egy határfelületi jelenség, és éppen ezért a tömbfázisban nem eredményezhetne változást. Ugyanazt a reakcióedényt alkalmaztam, mint amit az elôbbi kísérleteknél is.

$\mathrm{Az} \mathrm{R}=2,6$ arány mellett $25^{\circ} \mathrm{C}$-on végrehajtott kísérletekről készült fényképek láthatóak a 6.29. ábrán. Légréteget biztosítva a reakciótér felett hosszabb mintázatok jöttek létre. A rendelkezésre álló légteret tovább növeltem, ami a képek esetében $1 \mathrm{~cm}$ magas légrétegrôl $2 \mathrm{~cm}$ magasra való áttérést jelent. A stabil frontok átlagos alakját megvizsgálva az vehető észre, ha megnézzük a 6.30. ábrát, hogy a légréteg növelése nem okoz jelentôs eltérést $10 \mathrm{~mm}$ vastag távtartó esetében - ahol a legnagyobb a lehetőség a konvekció kialakulására -, mivel a keletkezett frontalakok hibán belül megegyeznek egymással. Elmondható, hogy a szabad légtér megduplázása nem befolyásolja a kialakuló mintázatot adott összetétel esetében, meghatározott edényszélesség felett, csak a megjelenése, hiszen az mintázatbeli különbséghez vezet.

Ezek után áttértem 2,8-as kezdeti koncentrációarány alkalmazására. Itt már kevesebb
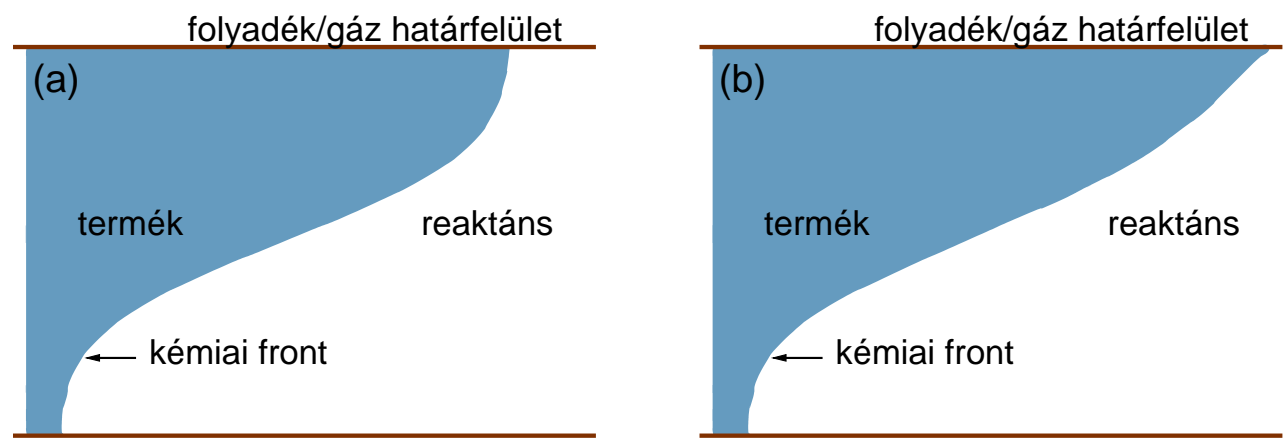

6.28. ábra. A reakciófront balról jobbra halad. Baloldalt helyezkedik el a kék színú, kisebb sûrúségű termékoldat, míg jobboldalt a nagyobb sưrúségú reaktánsoldat. 

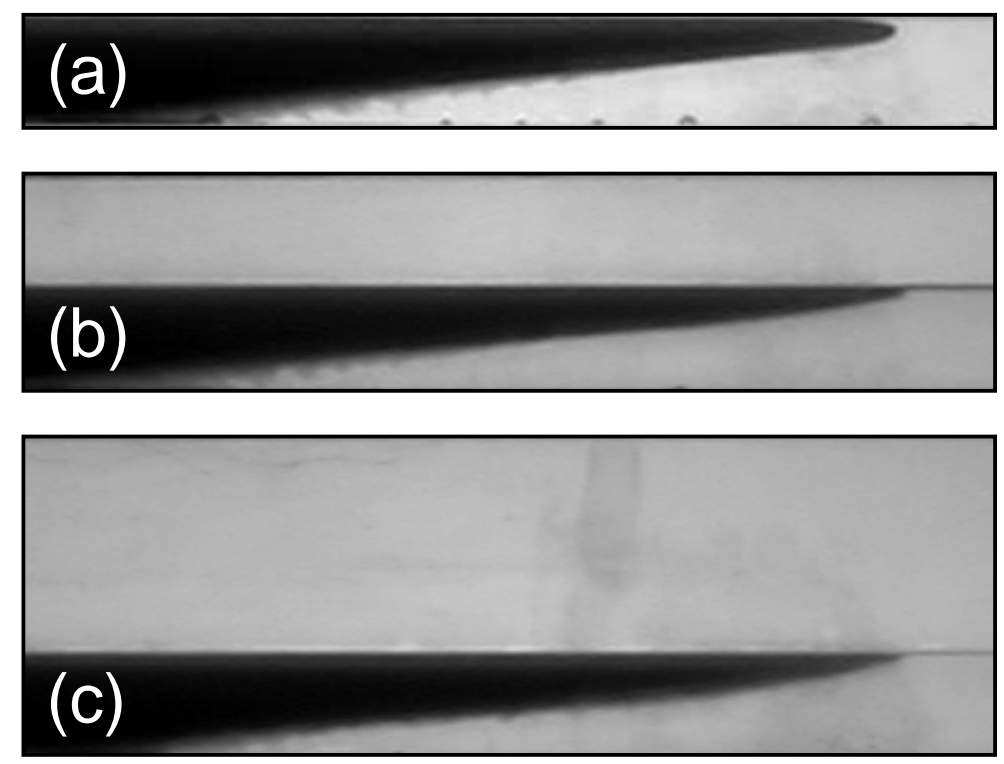

6.29. ábra. Az $R=2,6$ arány esetén véghez vitt kísérletekrôl készült képek, mikor a reakciófrontok balról jobbra haladtak: nincs szabad felszín (a), $1 \mathrm{~cm}$ légréteg (b), $2 \mathrm{~cm}$ légréteg (c).

jód képződik, amiből arra a következtetésre jutottam, hogy kisebb hatást kell tapasztalnom a létrejött frontalakok esetében a zárt és nyitott felszínes kísérletek eredményeinek az összehasonlítása után. Ezen kísérleti körülmények esetében készült fényképeket a 6.31. ábra szem-

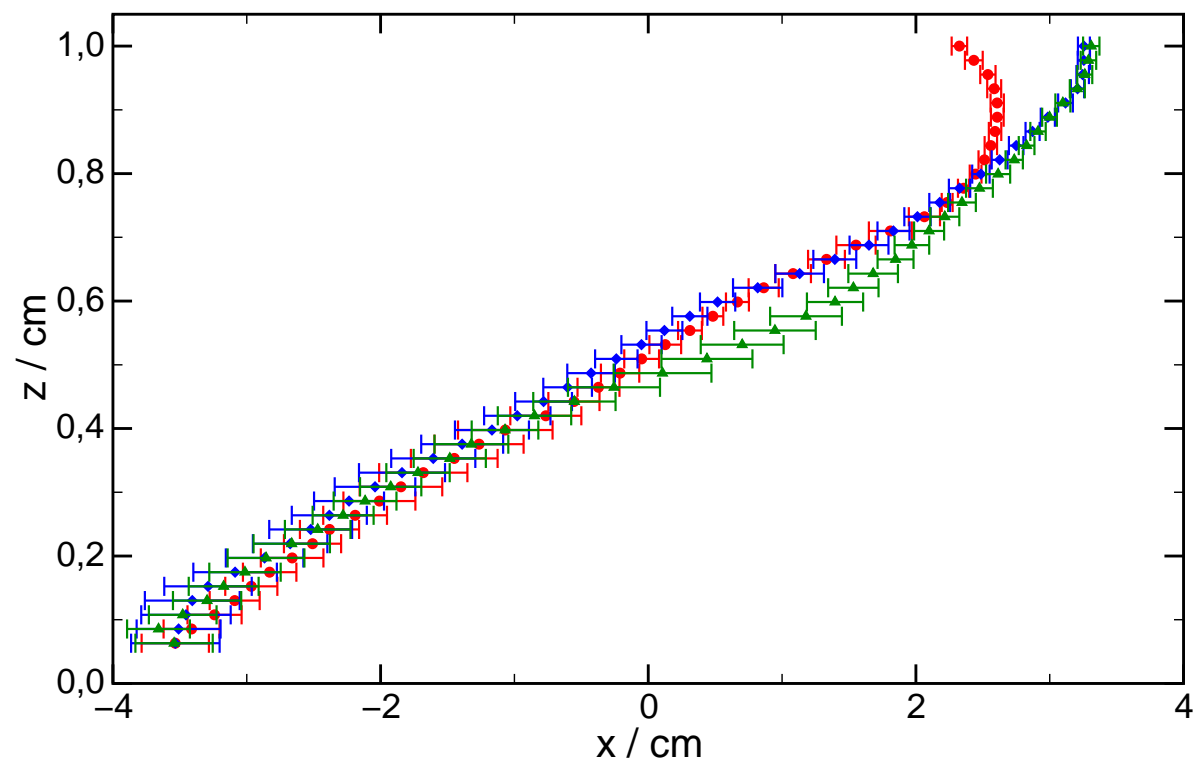

6.30. ábra. Az időben állandó mintázatra jellemző átlagos frontalakok különböző magasságú távtartók esetében $\mathrm{R}=2,6$ aránynál: nincs szabad felszín $\left(\mathrm{L}_{\mathrm{m}}=2,0 \pm 0,1 \mathrm{~cm} \bullet\right), 1 \mathrm{~cm}$ légréteg $\left(\mathrm{L}_{\mathrm{m}}=2,5 \pm 0,2 \mathrm{~cm} \diamond\right), 2 \mathrm{~cm}$ légréteg $\left(\mathrm{L}_{\mathrm{m}}=2,5 \pm 0,2 \mathrm{~cm} \boldsymbol{\Delta}\right)$. 


\section{(a)}

\section{(b)}

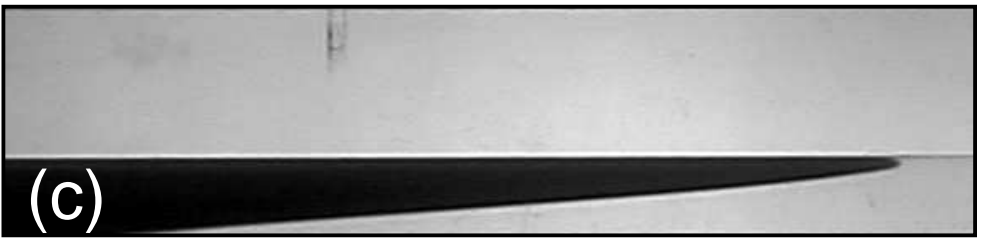

6.31. ábra. Balról jobbra haladó reakciófrontokról készült felvételek $\mathrm{R}=2,8$ arány esetén, $6 \mathrm{~mm}$ vastag távtartó alkalmazásakor: nincs szabad felszín (a), $1 \mathrm{~cm}$ légréteg (b), $2 \mathrm{~cm}$ légréteg (c).

lélteti. Szabad szemmel a reakciófrontok közötti különbség nem igazán érzékelhetô, de éppen ezért vannak segítségünkre az időben állandó mintázatra jellemző átlagos frontalakok, amiket a 6.32. ábra illusztrál. Itt is az tûnik fel, ami az elóbb is, hogy a légtér megjelenése módosítja - de nem olyan nagymértékben, mint a másik aránynál -, míg magasságának $1-2$ centiméterrel való megnövelése nem befolyásolja a mintázatképződést.

Az időben állandó mintázatok mennyiségi leírásához meghatároztam a keveredési hossz

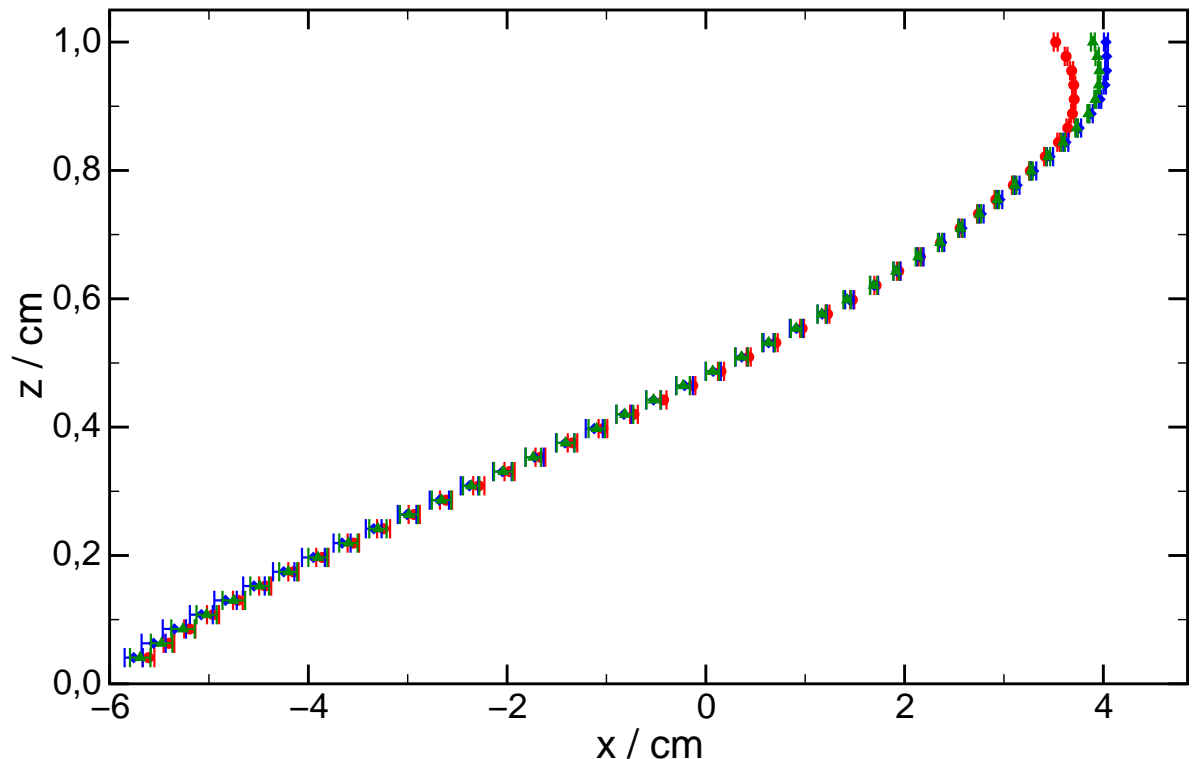

6.32. ábra. Az időben állandó mintázatra jellemző átlagos frontalakok különböző magasságú távtartók esetében $\mathrm{R}=2,8$ aránynál: nincs szabad felszín $\left(\mathrm{L}_{\mathrm{m}}=3,08 \pm 0,08 \mathrm{~cm} \bullet\right), 1 \mathrm{~cm}$ légréteg $\left(\mathrm{L}_{\mathrm{m}}=3,23 \pm 0,05 \mathrm{~cm} \vee\right), 2 \mathrm{~cm}$ légréteg $\left(\mathrm{L}_{\mathrm{m}}=3,2 \pm 0,2 \mathrm{~cm} \boldsymbol{\Delta}\right)$. 
6.11. táblázat. A keveredési hossz értékek különböző cellamagasságok és koncentrációarányok esetén $25^{\circ} \mathrm{C}$-on $1 \mathrm{~cm}$ magas oldatrétegnél $\left(\mathrm{R}=\left[\mathrm{H}_{3} \mathrm{AsO}_{3}\right]_{0} /\left[\mathrm{KIO}_{3}\right]_{0}\right)$.

\begin{tabular}{||c||c|c|c|c||}
\hline \hline \multirow{2}{*}{\multicolumn{1}{|c||}{$\mathrm{R}$}} & \multicolumn{4}{c||}{ Edény magassága $\left(L_{z} / \mathrm{cm}\right)$} \\
\cline { 2 - 5 } & Edényszélesség & 1 & 2 & 3 \\
\hline \hline 2,6 & $10 \mathrm{~mm}$ & $2,0 \pm 0,1$ & $2,5 \pm 0,2$ & $2,5 \pm 0,2$ \\
\hline 2,8 & $10 \mathrm{~mm}$ & $3,3 \pm 0,1$ & $3,6 \pm 0,3$ & $3,7 \pm 0,1$ \\
\hline 2,6 & $6 \mathrm{~mm}$ & $1,8 \pm 0,3$ & $2,0 \pm 0,1$ & $1,8 \pm 0,3$ \\
\hline 2,8 & $6 \mathrm{~mm}$ & $3,1 \pm 0,1$ & $3,2 \pm 0,1$ & $3,2 \pm 0,2$ \\
\hline 2,6 & $3 \mathrm{~mm}$ & $1,3 \pm 0,1$ & $1,5 \pm 0,1$ & $2,1 \pm 0,1$ \\
\hline 2,8 & $3 \mathrm{~mm}$ & $2,1 \pm 0,1$ & $2,1 \pm 0,1$ & $2,2 \pm 0,1$ \\
\hline \hline
\end{tabular}

és az amplitúdó értékeket is. A 6.11. táblázat foglalja össze az egyes reakcióedény magasságok és szélességek esetében számított $L_{m}$ eredményeket. Az edény szélességének csökkentésével csökkentek a keveredési hosszak. Az is szembetúnik, hogy a nagyobb kiindulási koncentrációarány mindig nagyobb $L_{m}$-t eredményez, ami az egyes fotók összehasonlításánál is észrevehetô, mivel hosszabb mintázat jött létre ebben az esetben (lásd a 6.29. és a 6.31. ábrát). Az átlagos frontalakok esetén tett megállapításomat alátámasztják a 6.11. táblázat adatai, hiszen szinte nincs különbség a 2 és $3 \mathrm{~cm}$ magas távtartók esetében a keveredési hosszakban adott összetétel esetében, ami a légréteg magasságától való függetlenséget bizonyítja. Ez a megállapítás a mérési hibán belül a dőlt betúvel jelölt adat esetében is fennáll. A több jódot termelő reaktánselegy-összetételt alkalmazva keskenyebb Hele-Shaw edényben a légréteg növelése további megnyúlást idéz elő az alakzatokban a légtér térfogatának nagyobb mértékú növekedése miatt.

Mivel a CT rendszerben nagy szerepe volt a pontos hőmérséklet ismeretének, ezért a IAA rendszerben is megnéztem, hogy ez mennyire fontos. A kiértékeléshez szükséges állandó alakzatok ebben az esetben magasabb hőmérsékleten is létrejöttek, ezért már csak a reprodukálhatóság biztosításának a kérdését kellett megválaszolni. Több kísérlet végeredménye is a hiba határon belül egybe esett. Szobahőmérsékleten és szobahőmérsékletre termosztált körülmények között is végrehajtottam a kísérleteket, és ahogyan az a 6.33. ábrán látható, nem volt eltérés a frontalakok között. Jelen esetben a front menti hőfejlődés által okozott lokális sưrúségcsökkenés nem annyira jelentôs, mint a klorit-tetrationát reakció esetében. Éppen ezért ezeket a reakciókat termosztálás nélkül hajtottam végre, egy körülményt kivéve. Mikor a hőmérséklet-növekedés okozta sürüségváltozás kiküszöbölése volt a célom, hiszen exoterm reakció ez is, akkor megint $4{ }^{\circ} \mathrm{C}$-ra termosztáltam a reakcióteret. Ezen kísérletek eredményét mutatja be a 6.34. ábra. Az látszik, hogy ekkor nem fedezhetô fel a Marangoni instabilitás hatása, hiszen az időben állandó mintázatra jellemző átlagos frontalakok hibán belül egybeesnek. 


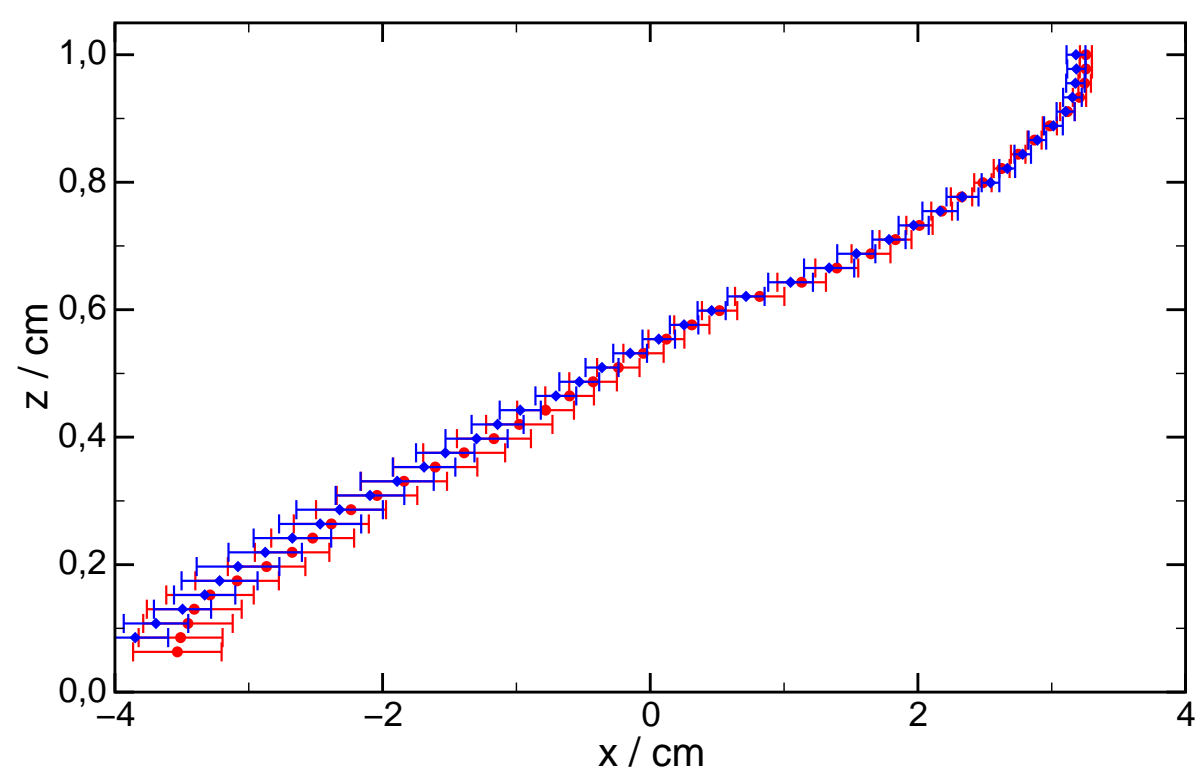

6.33. ábra. A termosztálás hatása az időben állandó mintázatra $\mathrm{R}=2,6$ arány esetében $10 \mathrm{~mm}$ vastag, $2 \mathrm{~cm}$ magas távtartónál: szobahőmérsékletre való termosztálás nélkül $\left(\mathrm{L}_{\mathrm{m}}=2,35 \pm 0,07 \mathrm{~cm} \bullet\right)$, termosztálás alkalmazása esetén $\left(\mathrm{L}_{\mathrm{m}}=2,37 \pm 0,07 \mathrm{~cm} \bullet\right)$.

A tapasztalt eredmények alátámasztása érdekében itt is megmértem a reaktáns- és a termékoldatok felületi feszültségét. Ezen méréseket Toulouse-ban hajtottam végre szintén Wilhelmy-lemez módszer segítségével 25 és $4{ }^{\circ} \mathrm{C}$-on mindkét általam alkalmazott kiindulási koncentrációaránynál. Nem lehetett eldönteni, hogy a kialakult állandó sebességgel terjedő állandó alakzat megnyúlást valóban a Marangoni instabilitás okozta, vagy csak a jód párolgása, és így ennek a kiderítésére is szolgáltak a felületi feszültség mérések. Az egyes $\gamma$ értékeket a 6.12. táblázatban adtam meg. Az $\mathrm{R}=2,8$ arány esetben nagyobb volt a változás, ami pont fordítottja annak, amit a kísérleti eredmények során tapasztaltam. Mivel az $\mathrm{R}=2,6$ aránynál már szilárd jód kiválása is tapasztalható volt, ez lehet a magyarázata annak, hogy kisebb lett a különbség a vártnál a $\gamma_{r}$ és a $\gamma_{t}$ között, hiszen a mérést a szilárd részecskék jelenléte nagyban befolyásolta. Itt is csak pár $\mathrm{mN} \mathrm{m}^{-1}$ felületi feszültségváltozás volt mér-

6.12. táblázat. A felületi feszültség mérés eredményei $\left(\mathrm{R}=\left[\mathrm{H}_{3} \mathrm{AsO}_{3}\right]_{0} /\left[\mathrm{KIO}_{3}\right]_{0}\right)$.

\begin{tabular}{||c||c|c|c|c||}
\hline \hline \multirow{2}{*}{$\mathrm{R}$} & \multirow{2}{*}{$\mathrm{T} /{ }^{\circ} \mathrm{C}$} & \multicolumn{3}{|c||}{$\gamma / \mathrm{mN} \mathrm{m}^{-1}$} \\
\cline { 3 - 5 } & reaktáns & termék & $\Delta$ \\
\hline \hline 2,6 & 25 & 72,0 & 65,1 & $-6,9$ \\
\hline 2,8 & 25 & 71,4 & 62,2 & $-9,2$ \\
\hline 2,6 & 4 & 75,6 & 73,6 & $-2,0$ \\
\hline 2,8 & 4 & 75,6 & 72,3 & $-3,3$ \\
\hline \hline
\end{tabular}




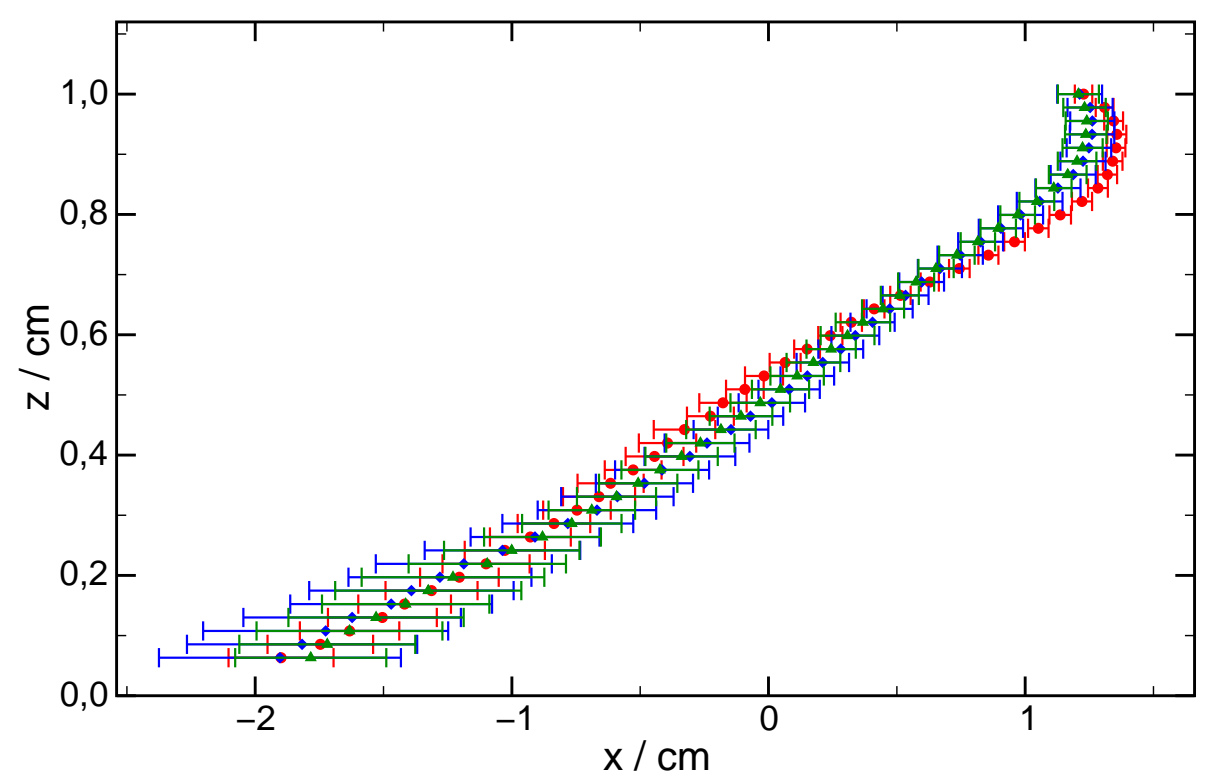

6.34. ábra. A reakciótér lehútésének hatása az időben állandó mintázatra $\mathrm{R}=2,6$ arány esetén $4{ }^{\circ} \mathrm{C}$-on, $10 \mathrm{~mm}$ vastag távtartónál: nincs szabad felszín $\left(\mathrm{L}_{\mathrm{m}}=1,03 \pm 0,04 \mathrm{~cm} \bullet\right), 1 \mathrm{~cm}$ légréteg $\left(\mathrm{L}_{\mathrm{m}}=0,96 \pm 0,09 \mathrm{~cm} \diamond\right), 2 \mathrm{~cm}$ légréteg $\left(\mathrm{L}_{\mathrm{m}}=1,01 \pm 0,13 \mathrm{~cm} \boldsymbol{\Delta}\right)$.

hető $25{ }^{\circ} \mathrm{C}$-on, de ez nagyobb mértékú volt a CT rendszerben mért értékekhez képest, míg $4{ }^{\circ} \mathrm{C}$-on viszont alig volt eltérés a mért értékek között. Éppen ezért, ahogy az a 6.34. ábrán is megfigyelhető, itt sincs alakbeli eltérés a mintázatokban az alacsonyabb hőmérsékleten,.

A 6.13. táblázat tartalmazza az ebben a rendszerben meghatározott frontsebességeket. Elmondható, hogy az egyes frontok sebessége itt is hibán belül megegyezett egy adott összetétel aránynál és cellavastagságnál a távtartó magasságának a növelése esetén. A frontok egy kicsivel, de lassabban haladtak a $\left[\mathrm{H}_{3} \mathrm{AsO}_{3}\right]_{0} /\left[\mathrm{KIO}_{3}\right]_{0}=2,6$-os aránynál a másik esethez képest.

6.13. táblázat. Az egyes cellamagasságokhoz és koncentrációarányokhoz tartozó frontsebességek mm s${ }^{-1}$ egységben kifejezve $25^{\circ} \mathrm{C}$-on, $1 \mathrm{~cm}$ magas oldatréteg esetén.

\begin{tabular}{||c||c|c|c|c||}
\hline \hline \multirow{2}{*}{\multicolumn{1}{|c||}{$\mathrm{R}$}} & \multicolumn{4}{c||}{ Edény magassága $\left(L_{z} / \mathrm{cm}\right)$} \\
\cline { 2 - 5 } & Edényszélesség & 1 & 2 & 3 \\
\hline \hline 2,6 & $10 \mathrm{~mm}$ & $0,45 \pm 0,04$ & $0,44 \pm 0,06$ & $0,45 \pm 0,03$ \\
\hline 2,8 & $10 \mathrm{~mm}$ & $0,48 \pm 0,02$ & $0,50 \pm 0,01$ & $0,48 \pm 0,05$ \\
\hline 2,6 & $6 \mathrm{~mm}$ & $0,39 \pm 0,01$ & $0,41 \pm 0,01$ & $0,41 \pm 0,04$ \\
\hline 2,8 & $6 \mathrm{~mm}$ & $0,41 \pm 0,01$ & $0,41 \pm 0,03$ & $0,41 \pm 0,03$ \\
\hline 2,6 & $3 \mathrm{~mm}$ & $0,28 \pm 0,02$ & $0,30 \pm 0,01$ & $0,37 \pm 0,02$ \\
\hline 2,8 & $3 \mathrm{~mm}$ & $0,29 \pm 0,01$ & $0,28 \pm 0,01$ & $0,28 \pm 0,01$ \\
\hline \hline
\end{tabular}


Az arzénessav jodátion által történő oxidációja során a hőmérséklet emelkedése $0,9{ }^{\circ} \mathrm{C}$ volt az $\mathrm{R}=2,6$ kiindulási koncentrációaránynál, míg a 2,8-as arány esetében $0,5^{\circ} \mathrm{C}$ hômérséklet-emelkedés következett be $6 \mathrm{~mm}$ vastag távtartónál. A Marangoni szám átlagosan a kétféle összetétel esetében $25^{\circ} \mathrm{C}$-on körülbelül 20000-nek, míg $4{ }^{\circ} \mathrm{C}$-on 7000 -nek adódott.

A IAA reakcióban sikerült kimutatni a Marangoni instabilitást. A kísérletek alapján megállapítható, hogy a légréteg megjelenése, vagyis a zárt rendszerről nyitott rendszerre való áttérés, változást eredményez a mintázatképződésben. A reakciótérben hosszabb mintázatok alakultak ki azáltal, hogy a nagyobb felületi feszültségú folyadék magára húzta a kisebb felületi feszültségú folyadékot. Elmondható, hogy ezen kísérletek során is minden esetben kialakult egy időben állandó frontalak. A keveredési hossz értékének tanulmányozásakor azt tapasztaltam, hogy a nagyobb mennyiségben jódot termelő $\left[\mathrm{H}_{3} \mathrm{AsO}_{3}\right]_{0} /\left[\mathrm{KIO}_{3}\right]_{0}=2,6 \mathrm{kez}-$ deti koncentrációaránynál nagyobb frontalak elnyúlás jön létre a szélesebb reakcióedények esetén. A $25^{\circ} \mathrm{C}$-ról $4{ }^{\circ} \mathrm{C}$-ra történő hőmérséklet-csökkentés a kialakult mintázat hosszának, vagyis a keveredési hossznak a csökkenését eredményezte, valamint az instabilitás megszúnését okozta a $\Delta \gamma$ csökkenése miatt. A légréteg megnövelése nem okoz eltérést, mivel a keletkezett frontalakok azonosak lettek a reakció feletti légtér nagyságának megduplázásának a hatására adott kiindulási koncentrációarány alkalmazása mellett. Valószínúsíthetô, hogy létezik egy meghatározott $M$, amely elérése után lép csak fel az általam tanulmányozott jelenség. Tiszta képet az ESA által támogatott mikrogravitációs kísérletek elvégzése után kaphatunk, mikor a sûrúségkülönbség által előidézett közegmozgás már nem lesz jelen a rendszerben, és csak a felületi feszültségváltozás hatására fellépő konvekciót lehet vizsgálni.

\subsubsection{Egyéb reakciók eredményei}

A jodát-arzénessav rendszer esetében módosítottam az eddigi receptúrát, mivel a kísérletek során viszonylag sok jód kiválását tapasztaltam a $\left[\mathrm{H}_{3} \mathrm{AsO}_{3}\right]_{0} /\left[\mathrm{KIO}_{3}\right]_{0}=2,6$ aránynál a reakció előrehaladása során, amelyet minimalizálni szerettem volna. Irodalmazás után poli(vinilalkoholt) adtam a reaktánsoldathoz, amely komplexet alkot a jódmolekulával. Ez egyrészt lehetővé tette a képződött jód oldatban való tartását kiküszöbölve a szilárd részecske kiválását, másrészt így kevesebb jód tudott kikerülni a légtérbe, ami a reakcióedény nehezebb tisztítását eredményezte. A poli(vinil-alkohol) (PVA) koncentrációja a reaktánselegyben 1,2 g $1^{-1}$ volt. Már korábban sikerült Salinnak és munkatársainak állandó sebességgel terjedô állandó alakzatokat létrehozni PVA alkalmazásával [91]. A létrejött frontalakjaim megegyeztek a náluk tapasztalható frontalakokkal azonos cella orientációnál. Hozzájuk képest a kísérleteimet hosszabb és szélesebb Hele-Shaw edényben hajtottam végre, illetve bizonyos esetekben az oldat felett légréteget is alkalmaztam. Azt tapasztaltam, hogy ebben a reakcióban igen nagymértékú volt a plusz falak nedvesedése, amikor a szabad légtér is jelen volt, ami a sík felszín eltûnését idézte elő. Tényleg nem tapasztaltam jódkiválást az idő előrehaladtával, vi- 
szont mégsem alkalmas a felületi feszültség különbség hatásának vizsgálatára ez a receptúra, a nagyfokú nedvesedés miatt, ami meggátolja a kísérletek összehasonlíthatóságát.

Ezek után egy új, a csoportunkban még nem vizsgált reakció-diffúz rendszert kezdtem el tanulmányozni, ami a szintén jodidionra nézve autokatalitikus jodát-szulfit reakció volt az arzénessav kiküszöbölése miatt. A szulfition jodátionnal történő oxidációja nem más, mint a régóta ismert Landolt reakció [101]. Ez a rendszer sem volt alkalmas a közegmozgás mintázatképző hatásának vizsgálatára, mert vagy annyira lassú volt, hogy nem lehetett megfelelően kiértékelni, vagy ha a sebessége kielégítőnek bizonyult, akkor elôtérbe került a direkt oxidáció. A lejátszódás szempontjából ebben az esetben is kulcsfontosságú volt a kiindulási komponensek koncentrációjának egymáshoz viszonyított aránya. A kísérleteimnél a jodátionok voltak feleslegben, és jód, trijodid valamint szulfátionok képződtek a reakció során. Indikátorként itt is a keletkezett jód sárga színét használtam ki. 


\section{7. fejezet}

\section{Összefoglalás}

Elsôre nem is gondolnánk, hogy milyen nagy hatással vannak a különféle transzportfolyamatok a mindennapi életünkre, pedig számos megnyilvánulási formájukkal percről percre befolyásolják a körülöttünk lévő világot. Nemcsak a napi időjárás kialakításában töltenek be fontos szerepet a különbözô légköri képződmények előidézésével (pl. hurrikán, felhő), hanem a leggyakrabban előforduló anyagtranszportok eredményezik a nyílt vizeken kialakuló tengeráramlatokat is. A különböző kôzetlemezek, szennyeződések is általuk tudnak mozgásba kerülni. Mivel ezek a jelenségek a természet eróinek a megnyilvánulásakor igen erőteljesen hatnak ránk, ezért nélkülözhetetlen a kísérleti tanulmányozásuk. Az ily módon létrejövő térbeli mintázatokat autokatalitikus modellreakciók segítségével részletesebben is meg lehet vizsgálni.

A mintázatképződés megvalósulásához több lehetőség is rendelkezésre áll a transzportfolyamatok fajtáától, a kémiai reakció sajátságaitól, illetve az adott reakcióközegben fennálló erôterektől függoóen. Leggyakrabban a diffúzió, a konvekció, illetve a külső elektromos erôtér által az ionokra gyakorolt migráció eredményezi a világban előforduló különféle anyagféleségek térbeli elmozdulását. Leginkább súrúségkülönbség, a viszkozitás és a felületi feszültség változása eredményeképpen jön létre a közegmozgás. A kísérleti munkámban autokatalitikus modellreakciók segítségével a kémiai front két oldalán indukált sứrúségkülönbség és felületi feszültségváltozás hatására kifejlődô konvekciót, valamint a reaktánsok és a termékek közti éles határvonal diffúzió révén bekövetkező módosulását tanulmányoztam részletesebben. Ez elengedhetetlennek bizonyult, hiszen a XX. század végén hirtelen egyre szélesebb körben kezdtek elterjedni a számítógépek, és ez igen jelentős befolyásoló tényezőként jelent meg az elméleti modellek kidolgozásában.

A határfelületi jelenségek vizsgálatakor felállított elméleti modellek kísérleti alátámasztása során elsősorban a jodát-arzénessav és a klorit-tetrationát rendszerben dolgoztam. Mindkét exoterm reakcióban bekövetkezô kémiai összetétel változása és hőfelszabadulás miatt fellépô oldatsưrúség-változás eltérô reaktáns- és termékoldat sưrúséget eredményez. Gravi- 
tációs erőtérben különböző térállású reakcióedényekben lejátszatva ezeket a reakciókat az előbb leírt tulajdonságok mintázatképződést eredményeznek, hiszen ekkor közegmozgás indukálódik a rendszerben. A konvekció megnyilvánulásának másik lehetősége a Marangoni instabilitás, ami a felületi feszültséggradiens hatására létrejövő anyagátvitel következtében lép fel a folyadék/gáz határvonalon. Hatására a nagyobb felületi feszültségú folyadék magára húzza a kisebb felületi feszültségú folyadékot a határfelület mentén.

Frontszerúen terjedő kémiai reakciókban létrejövő mintázatképződéseket vizsgáltam a doktori munkám során. Az elsô célom a diffúzív instabilitás kimutatása volt a jodát-arzénessav reakcióban a hidrogénionok megkötésével. A különböző tér- és időbeli alakzatok regisztrálása és mennyiségi jellemzése mellett, bizonyos esetekben megmértem magában a reakcióösszetételnek megfelelő közegben a kinetikai szempontból fontos komponensek diffúziós együtthatóját, amihez az in situ módon is alkalmazható pulzusgradiens spin echó (PFGSE) NMR módszert használtam. Elméleti számítások során azt jósolták, hogy a mintázat mennyiségi jellemzője - vagyis a keveredési hossz - a reakcióedény magasságának második hatványával arányos. A korábbi kísérletek arra engedtek következtetni, hogy ez az arányosság nem pontosan így áll fenn, ezért célul tűztem ki a skálázási törvény kísérleti meghatározását is a jodát-arzénessav reakcióban. Továbbá megvizsgáltam azt is, hogy a klorit-tetrationát szintén autokatalitikus reakcióban történő makroszkopikus önszerveződésre milyen hatással van a harmadik dimenzió kiszélesítése. A munkám befejező részében pedig a Marangoni instabilitás hatására kialakuló közegmozgást tanulmányoztam a két modellreakció esetén.

Az arzénessav jodátionnal történő oxidációja során, valamint a klorit- és a tetrationátion közti reakcióban a reaktánsok kezdeti koncentrációjának arányától függôen, jól definiált éles határvonal jeleníti meg a kialakult mintázatot úgy, hogy állandó súrúségkülönbség jön létre a front mindkét oldalán. A legtöbb kísérletet Hele-Shaw edényben hajtottam végre, ami két egymáshoz közeli párhuzamos plexi lapból állt, amik közé különböző vastagságú távtartót helyeztem el, attól függően, hogy mi volt a vizsgálatom célja. Abban az esetben, amikor a Marangoni instabilitás hatását kívántam megvizsgálni, további $1 \mathrm{~cm}$ magas és $1 \mathrm{~mm}$ széles falakat építettem be a távtartó két oldalára, hogy azok megkönnyítsék a cella feltölthetôségét. Függőleges reakcióedényben vízszintesen haladó frontok hosszútávú viselkedésének mennyiségi leírásához a Hele-Shaw cellát úgy módosítottam, hogy a hosszát kétszeresére növeltem, szélességét pedig 3 és $10 \mathrm{~mm}$ között változtattam. A diffúzív frontinstabilitást a jodát-arzénessav rendszerben egy reaktor segítségével tanulmányoztam. A háromdimenziós szerkezetek vizsgálatára pedig egy üvegcsövet alkalmaztam, ami megkönnyítette az oldalnézeti és a felülnézeti kép egyszerre történő rögzítését. A front terjedését képfeldolgozó rendszer segítségével követtem nyomon, majd ezt követően a rögzített képek alapján kvantitatíven jellemeztem a kialakult szerkezeteket.

A mintázatképződés kezdeti szakaszának mennyiségi leírásához meghatároztam a disz- 
perziós görbéket, míg a minta hosszútávú viselkedésének figyelemmel kíséréséhez az erre sokkal inkább alkalmasabb keveredési hossz értékeket számoltam ki. Először megalkottam az egyes frontpozíciókat a rögzített képek alapján, majd ezeket különböző hullámhosszúságú komponensekre bontottam fel, és ezek amplitúdójának időbeli változása alapján meg tudtam határozni az adott hullámhosszúságú komponensek növekedési együtthatóit, amivel az $\omega-k$ diszperziós grafikonhoz jutottam. Ezek után a frontprofilok jellemzésére alkalmas keveredési hosszt $\left(L_{m}\right)$ és amplitúdót $(A)$ határoztam meg. Az előbbi az átlagos frontalaktól való átlagos eltérésként definiálható, míg az utóbbi pedig a legelőrehaladottabb és a leglemaradottabb pontok közötti távolságként. A keveredési hossz figyelembe veszi a front összes pontját, míg az amplitúdó csak két pontból jellemzi a reakciófrontot. Az átlagos frontalak elkészítéséhez az átlagos frontpozíciót ki kell vonni minden egyes pozícióból, majd a görbéket a front terjedési irányára merőleges irányba eső koordináta szerint kell átlagolni.

Sikerült kimutatni a diffúzív instabilitást konvekciómentes közegben a jodát-arzénessav rendszerben úgy, hogy lecsökkentettem az autokatalizátor fluxusát a reaktánsokéhoz képest. A kettôs autokatalízissel bíró reakcióban jóval nagyobb amplitúdójú és hullámhosszú cellák alakultak ki a hidrogénion szelektív immobilizálásával - karboxilátcsoportokat tartalmazó poliakrilamid-gélben -, mint mikor a jodidiont $\alpha$-ciklodextrinnel kötötték meg pufferált közegben. A kialakuló front továbbra is fennálló kis mértékú instabilitásának az a magyarázata, hogy a két autokatalizátor egyidejúleg van jelen a rendszerben, valamint az, hogy ezek közül az egyik a hidrogénion, aminek vizes oldatban nagy a mozgékonysága. Továbbá az is elmondható, hogy a képződő hidrogénion immobilizálása nem növelhető határtalanul, mert a diffúzív instabilitás egy megkötési értéken túl csökken, mivel az autokatalizátor fluxusának megfelelő mértékú csökkentése a reakció sebességét túlságosan lecsökkenti. A diffúziós viszonyok pontos feltérképezése érdekében az in situ módon mért diffúziós koefficiensek alapján megállapítható, hogy elhanyagolható az eltérés a savas, valamint a lúgos közegú oldatokban mérhető diffúziós együtthatók között.

Elegendően hosszú és keskeny reakcióedényben állandó sebességgel terjedô állandó alakzatok jöttek létre a skálázási törvény kísérleti tanulmányozása során, amit szintén a jodátarzénessav rendszerben végeztem el. Elmondható, hogy a keveredési hossz az elméleti számítások során jósolt eredményétől eltérően nem négyzetes arányosság szerint változott az edény magasságával, valamint, hogy a hatványkitevő értéke függött a reaktánsok kezdeti koncentrációinak arányától. A hőmérséklet csökkentésének hatását is megvizsgáltam, és azt tapasztaltam, hogy a keveredési hossz értékek csökkentek, de ez a skálázási törvényben szereplő hatványkitevőre nem volt befolyással. A keveredési hossz és a centiméteres nagyságrendű oldatmagasság között fennálló skálázási összefüggésre kapott eredményeket összehasonlítva a klorit-tetrationát rendszer eredményeivel, megállapítható, hogy létezik egy univerzális skálázási kitevő $(1,32 \pm 0,08)$, amelynek az értéke független a kísérletek során 
fellépő sưrűségváltozás előjelétől.

A háromdimenzióban létrejövő mintázatok vizsgálatakor azt tapasztaltam, hogy oszcilláló szerkezetek kialakításához polielektrolit hozzáadása szükséges az adott rendszer esetében. Az exoterm CT reakció során végbemenô hőfelszabadulás stabilizálja a mintázatképződést egy adott oldatréteg-vastagságtól kezdődően vízszintesen haladó reakciófrontok esetében. Megállapítottam, hogy lehetséges vastag oldatrétegekben állandó sebességgel terjedő állandó alakzatokat létrehozni, továbbá azt is, hogy a mintázatképződés egységes volt. Felülnézetből az alakzat hátsó részén a rendelkezésre álló térnek megfelelően különböző nagyságú, de azonos nyílási szögú $\mathrm{V}$ formájú minták keletkeztek a reakció lejátszódása során. A stabil alakzatot jellemző felülnézeti és oldalnézeti keveredési hossz független volt az oldatvastagságtól egy meghatározott edényszélesség felett.

A munkám befejező részében pedig sikerült kimutatni a Marangoni instabilitást. Először a klorition és a tetrationátion közti reakcióban próbáltam tenzid hozzáadásával befolyásolni a kezdeti felületi feszültség értékeket, de ott nem lehetett ezt a jelenséget egyértelmúen azonosítani. Ezután a IAA reakcióban képződött felületaktív jód hatására már szemmel látható módosulás következet be a mintázatban. Megállapítható volt, hogy a légréteg megjelenése, vagyis a zárt rendszerről nyitott rendszerre való áttérés, változást eredményezett a mintázatképződésben. A rendszeren véghez vitt hőmérséklet-csökkentés a kialakult alakzatok hosszának, vagyis a keveredési hossznak a csökkenését eredményezte, valamint a felületi feszülttség különbség csökkenésének következtében az instabilitás megszúnését okozta. A légréteg megnövelése nem okozott jelentős eltérést, mivel a keletkezett frontalakok azonosak lettek a reakció feletti légtérmagasság megduplázásának a hatására. 


\section{8. fejezet}

\section{Summary}

There is a huge impact of various transport processes in our surrounding, which may affect our everyday's life. They have an important role in the daily weather with causing various formations in the atmosphere (for example hurricanes, clouds). The most common material transport can also generate sea currents in the oceans. Different tectonic plates, or chemical contaminations can be moved via them. Because these phenomena affect us strongly, it is essential to study them experimentally. In my work, I will investigate them through autocatalytic model reactions in more detail.

To the realization of pattern formation may have more options depending on the type of transport processes, the chemical reactions, and the existing external fields. Generally, materials can be transferred through diffusion, convection, and in the presence of external electrical field, ionic migration. The fluid motion can be influenced by the change in density, in viscosity, or in the surface tension. In my dissertation I experimentally investigated in detail diffusive instabilities and also convection arising from density or/and surface tension changes during an autocatalytic reaction. By the end of the twentieth century computers began to spread suddenly, and the number of established theoretical models is rapidly increased which demanded experimental support with quantitative description.

Interfaces separating reactants from products evolving in the autocatalytic iodate-arsenous acid and the chlorite-tetrathionate reactions are investigated to confirm the theoretical models. The density of reactants and products are different in both exothermic reaction because not only the chemical composition changes but also substantial heat may be released. When these reactions are carried out in reaction vessels with different orientations in the presence of gravity field, fluid motion induced in the system leads to distortions in the interface. Convection can also result in a new type of hydrodynamic instability, called Marangoni instability, when material is transported along the liquid/gas interface due to surface tension gradient. The interface is also distorted, since the liquid with a higher surface tension pulls the liquid with a smaller surface tension. 
During my doctoral research, I investigated chemical fronts in various autocatalytic reactions. The first goal was to detect diffusive instability in the iodate-arsenous acid reaction with binding only the hydrogen ions. Besides monitoring the spatiotemporal pattern formations and quantitatively characterizing the evolving structures, I have measured the diffusion coefficients of kinetically important components in situ with pulsed field gradient spin echo (PFGSE) NMR method. Theoretical calculations predicted that the mixing length, characterizing the pattern, increases with the square function of the vessel height when the height of the reaction vessel is increased. Previous studies, however, suggested that this proportionality is not valid, so my aim was to determine the scaling law experimentally in the iodatearsenous acid reaction under several chemical compositions. In addition, I investigated the effect of widening in the third dimension on the self-organization of the chlorite-tetrathionate reaction. Finally, the Marangoni instability was studied in the two model reactions.

When the arsenous acid is oxidized with iodate ion, or the tetrathionate ion with chlorite ion, a sharp interface can develop depending on the initial concentration ratio. This welldefined line is called a chemical front and it creates a constant density difference at the two sides. In most of the experiments, Hele-Shaw reaction vessels were used consisting of two parallel Plexiglas walls separated by spacers of different thickness depending on the purpose of the investigation. To study Marangoni instability, 1-cm high and 1-mm thick extra walls were inserted to the two sides of the spacer which besides creating a flat liquid/gas interface also facilitates the loading of the vessel. We doubled the lengths of vertical HeleShaw vessels while their widths were varied between 3 and $10 \mathrm{~mm}$ in order to describe the long time behavior of the horizontally propagating fronts. A glass rectangular slab was the suitable vessel for testing the three-dimensional structures, since it facilitated the recording of images parallel from side and top view. The diffusive instability of the iodate-arsenous acid reaction was investigated with a special reactor. The front propagation was recorded by an image processing system, after which the structures were characterized quantitatively.

I determined dispersion relations to quantitatively describe the initial front evolution, while for the characterization of the long time behavior I calculated the mixing lengths. First, front profiles were created from the saved images of the traveling front. Then the front shapes were decomposed into components with different wavelengths. Their amplitude initially grows exponentially in time, with the exponent termed as growth rate. The growth rate $(\omega)$ of perturbations with different wavenumbers $(k)$ were calculated resulting in the dispersion curve of $\omega-k$. Then the evolving pattern was quantitatively described by the mixing length $\left(L_{m}\right)$ and the amplitude $(A)$. The former was defined as the average deviation of the front profiles, while the latter as the distance between the most advanced and the slowest points. The mixing length is a better definition since it considers all points of the front, while the amplitude is given from only two points of the reaction front. The average front profile was 
prepared by subtracting the average front position from each point, and then averaging the curves in the direction perpendicular to the front propagation.

The diffusion-driven instability was detected experimentally in the iodate-arsenous acid reaction when the autocatalyst was slowed down in convection free environment. The IAA system has two autocatalysts: iodide and hydrogen ions. Cellular patterns with greater amplitudes develop when hydrogen ions are immobilized selectively - in carboxylate containing polyacrylamide gels - compared to those when iodide ions were bound to cyclodextrin in a buffered medium. The cell amplitudes, and hence, the instability are still smaller compared to the CT system because two autocatalysts are in the system and one of them is hydrogen ion which has higher mobility in aqueous solutions. Furthermore, we have shown that the immobilization of hydrogen ion can not be increased without any limit above which the diffusive instability decreases because of the decrease in the reaction rate. The diffusion coefficients of certain compounds were measured by in situ PFGSE-NMR both in acidic and in basic solutions. The results clearly illustrate that their difference is negligible.

In a sufficiently long and narrow reaction vessel, a front, characterized with its mixing length, with constant shape and velocity evolves in the IAA reaction when the solution height is varied. The mixing length scales with the height of the reaction vessel, but the scaling exponent significantly differs from that suggested by model calculations. Furthermore, the exponent not only differs from the numerically predicted two but also greatly depends on the stoichiometric ratio of the reactants. I have also investigated the effect of reducing the temperature from $25^{\circ} \mathrm{C}$ to $4{ }^{\circ} \mathrm{C}$. The mixing length decreases on decreasing the temperature, while the scaling exponent remains unchanged. The relationship between the mixing length and the height of the solution is similar in the chlorite-tetrathionate system. The exponents of the systems equal within the experimental error. We thus concluded that there exists a universal scaling exponent $(1,32 \pm 0,08)$ for thin reaction fronts, the value of which is independent of the sign of the density change during the experiments.

I have found experimentally that oscillatory pattern can developed only by adding polyelectrolyte to the reactant solution when three-dimensional structure was studied. In the exothermic CT reaction heat liberates and hence the spatiotemporal pattern is stabilized which can be observed for horizontally propagating reaction fronts in a sufficiently thick solution layer. We have shown that the stable front with constant velocity and shape may develop. Two characteristic regions are found: a leading symmetric edge and a V-shaped trailing cusp. The final stable pattern from the side view is independent of the solution thickness. The cusp has a constant angle for solution thickness in the range of $11-21 \mathrm{~mm}$, in which case the front speed is also independent of the thickness.

In the last part of my dissertation, Marangoni instability is demonstrated. First, the surface tension is influenced with surfactants in the chlorite-tetrathionate reactions but the 
change is not sufficient to observe the instability. Then, the IAA reaction is used because during the reaction the surface-active iodine forms as a product. The introduction of the air gap yields a different structure with greater mixing lengths, since the reactant solution with higher surface tension pulls the product solution with lower surface tension. When the temperature is reduced from $25{ }^{\circ} \mathrm{C}$ to $4{ }^{\circ} \mathrm{C}$, the mixing length not only decreases but also Marangoni instability is eliminated, because the surface tension difference between the reactant and product solutions is reduced. The doubling of the air gap does not cause any deviation in the profiles since they are the same within the experimental error. 


\section{Irodalomjegyzék}

[1] P. W. Atkins, Fizikai kémia III: Változás, Tankönyvkiadó, Budapest (1992).

[2] A képek forráshelyei: ${ }^{1}$

- http://eoimages.gsfc.nasa.gov/images/imagerecords/15000/15395/ Katrina2_TMO_2005240_lrg.jpg

- http://static6.origos.hu/i/1005/20100510brentonsz.jpg

- http://www.magyar-mernok.hu/files/tudor/vulkán.jpg

[3] R. E. Liesegang, Ueber einige Eigenschaften von Gallerten, Naturwissenchaftliche Wochenschrift 11, 353-362 (1896).

[4] D. E. H. Jones, U. Walter, The Silicate Garden Reaction in Microgravity: A Fluid Interfacial Instability, J. Coll. and Sci. 203, 286-293 (1998).

[5] G. Póta, G. Stedman, Exotic behaviour of chemical reaction systems, Models in Chemistry 131, 229-268 (1994).

[6] D. Horváth, V. Petrov, S. K. Scott, K. Showalter, Instabilities in propagating reaction-diffusion fronts, J. Chem. Phys. 98, 6332-6343 (1993).

[7] M. Fuentes, M. N. Kuperman, J. Boissonade, E. Dulos, F. Gauffre, P. De Kepper, Dynamical effects induced by long range activation in a nonequilibrium reaction-diffusion system, Phys. Rev. E. 66, 056205 (2002).

[8] K. Showalter, Quadratic and cubic reaction-diffusion fronts, Nonlinear Science Today 4, 1-10 (1995).

[9] D. Horváth, K. Showalter, Instabilities in propagating reaction-diffusion fronts of the iodatearsenous acid reaction, J. Chem. Phys. 102, 2471-2478 (1995).

[10] D. Horváth, Á. Tóth, Diffusion-driven front instabilities in the chlorite-tetrathionate reaction, J. Chem. Phys. 108, 1447-1451 (1998).

\footnotetext{
${ }^{1}$ Valamennyi internetes forráshely 2012. 07. 16-án még elérhető volt.
} 
[11] T. Rica, É. Pópity-Tóth, D. Horváth, Á Tóth, Double-diffusive cellular fingering in the horizontally propagating fronts of the chlorite-tetrathionate reaction, Physica D 239, 831-837 (2010).

[12] Á. Tóth, I. Lagzi, D. Horváth, Pattern formation in reaction-diffusion systems: Cellular acidity fronts, J. Phys. Chem. 100, 14837-14839 (1996).

[13] Zs. Virányi, Á. Tóth, D. Horváth, Lateral instability induced by an inhomogeneous electric field, Chem. Phys. Lett. 401, 575-578 (2005).

[14] M. Fuentes, M. N. Kuperman, P. De Kepper, Propagation and interaction of cellular fronts in a closed system, J. Phys. Chem. A 105, 6769-6774 (2001).

[15] Á. Tóth, D. Horváth, W. van Saarloos, Lateral instabilities of cubic autocatalytic reaction fronts in a constant electric field, J. Chem. Phys. 111, 10964-10968 (1999).

[16] L. Rayleigh, Investigation of the character of the equilibrium of an incompressible heavy fluid of variable density, Proc. Math. Soc. 14, 170-177 (1883).

[17] G. Taylor, The instability of liquid surfaces when accelerated in a direction perpendicular to their planes. I., Proc. Roy. Soc. A 201, 192-196 (1950).

[18] D. J. Lewis, The instability of liquid surfaces when accelerated in a direction perpendicular to their planes. II., Proc. Roy. Soc. A 202, 81-96 (1950).

[19] P. G. Saffman, G. Taylor, The penetration of a fluid into a porous medium or Hele-Shaw cell containing a more viscous liquid, Proc. Roy. Soc. A 245, 312-329 (1958).

[20] S. Hill, Channelling in packed columns, Chem. Eng. Sci. 1, 247-253 (1952).

[21] A. De Wit, G. M. Homsy, Viscous fingering in periodically heterogeneous porous media. I. Formulation and linear stability, J. Chem. Phys. 107, 9609-9618 (1997).

[22] A. De Wit, G. M. Homsy, Viscous fingering in periodically heterogeneous porous media. II. Numerical simulations, J. Chem. Phys. 107, 9619-9628 (1997).

[23] T. Rica, D. Horváth, Á. Tóth, Density fingering in acidity fronts: Effect of viscosity, Chem. Phys. Lett. 408, 422-425 (2005).

[24] C. Normand, Y. Pomeau, M. G. Velarde, Convective instability: A physicist's approach, Rev. Mod. Phys. 49, 581-624 (1977).

[25] Gy. Bazsa, I. R. Epstein, Traveling waves in the nitric acid-iron(II) reaction, J. Phys. Chem. 89, 3050-3053 (1985).

[26] I. Nagypál, Gy. Bazsa, I. R. Epstein, Gravity-induced anisotropies in chemical waves, J. Am. Chem. Soc. 108, 3635-3640 (1986). 
[27] J. A. Pojman, I. R. Epstein, Convective effects on chemical waves. 1. Mechanisms and stability criteria, J. Phys. Chem. 94, 4966-4972 (1990).

[28] J. A. Pojman, I. R. Epstein, T. J. McManus, K. Showalter, Convective effects on chemical waves. 2. Simple convection in the iodate-arsenous acid system, J. Phys. Chem. 95, 1299-1306 (1991).

[29] J. Masere, D. A. Vasquez, B. F. Edwards, J. W. Wilder, K. Showalter, Nonaxisymmetric and axisymmetric convection in propagating reaction-diffusion fronts, J. Phys. Chem. 98, 65056508 (1994).

[30] D. A. Vasquez, J. M. Littley, J. W. Wilder, B. F. Edwards, Convection in chemical waves, Phys. Rev. E 50, 280-284 (1994).

[31] J. A. Pojman, I. P. Nagy, I. R. Epstein, Convective effects on chemical waves. 3. Multicomponent convection in the iron(II)-nitric acid system, J. Phys. Chem. 95, 1306-1311 (1991).

[32] J. A. Pojman, A. Komlósi, I. P. Nagy, Double-diffusive convection in traveling waves in the iodate-sulfite system explained, J. Phys. Chem. 100, 16209-16212 (1996).

[33] A. Komlósi, I. P. Nagy, Gy. Bazsa, J. A. Pojman, Convective chemical fronts in the 1,4cyclohexanedione-bromate-sulfuric acid-ferroin system, J. Phys. Chem. A 102, 9136-9141 (1998).

[34] J. Huang, D. A. Vasquez, B. F. Edwards, P. Kolodner, Onset of convection for autocatalytic reaction fronts in a vertical slab, Phys. Rev. E 48, 4378-4386 (1993).

[35] J. Huang, B. F. Edwards, Pattern formation and evolution near autocatalytic reaction fronts in a narrow vertical slab, Phys. Rev. E 54, 2620-2627 (1996).

[36] A. De Wit, Fingering of chemical fronts in porous media, Phys. Rev. Lett. 87, 054502 (2001).

[37] J. Martin, N. Rakotomalala, D. Salin, M. Böckmann, Buoyancy-driven instability of an autocatalytic reaction front in a Hele-Shaw cell, Phys. Rev. E 65, 051605 (2002).

[38] L. Šebestíková, J. D’Hernoncourt, M. J. B. Hauser, S. C. Müller, A. De Wit, Flow-field development during finger splitting at an exothermic chemical reaction front, Phys. Rev. E 75, 026309 (2007).

[39] J. Yang, A. D’Onofrio, S. Kalliadasis, A. De Wit, Rayleigh-Taylor instability of reactiondiffusion acidity fronts, J. Chem. Phys. 117, 9395-9408 (2002).

[40] D. A. Vasquez, A. De Wit, Dispersion relations for the convective instability of an acidity front in Hele-Shaw cells, J. Chem. Phys. 121, 935-941 (2004).

[41] M. Böckmann, S. C. Müller, Growth rates of the buoyancy-driven instability of an autocatalytic reaction front in a narrow cell, Phys. Rev. Lett. 85, 2506-2509 (2000). 
[42] http://www-math.mit.edu/ bush/tears.jpg

[43] A. De Wit, Miscible density fingering of chemical fronts in porous media: Nonlinear simulations, Phys. Fluids 16, 163-175 (2004).

[44] L. Rongy, A. De Wit, Steady Marangoni flow traveling with chemical fronts, J. Chem. Phys. 124, 164705 (2006).

[45] L. Rongy, A. De Wit, Solitary Marangoni-driven convective structures in bistable chemical systems, Phys. Rev. E 77, 046310 (2008).

[46] L. Rongy, Influence of Marangoni and buoyancy convection on the propagation of reactiondiffusion fronts, PhD disszertáció, Brüsszel (2008).

[47] D. Horváth, T. Bánsági Jr., Á. Tóth, Orientation-dependent density fingering in an acidity front, J. Chem. Phys. 117, 4399-4402 (2002).

[48] L. Szirovicza, I. Nagypál, E. Boga, An algorithm for the design of propagating acidity fronts, J. Am. Chem. Soc. 111, 2842-2845 (1989).

[49] A. K. Horváth, I. Nagypál, I. R. Epstein, Three autocatalysts and self-inhibition in a single reaction: A detailed mechanism of the chlorite-tetrathionate reaction, Inorg. Chem. 45, 98779883 (2006).

[50] A. K. Horváth, I. Nagypál, G. Peintler, I. R. Epstein, Autocatalysis and self-inhibition: coupled kinetic phenomena in the chlorite-tetrathionate reaction, J. Am. Chem. Soc. 126, 6246-6247 (2004).

[51] A. K. Horváth, A three-variable model for the explanation of the "supercatalytic" effect of hydrogen ion in the chlorite-tetrathionate reaction, J. Phys. Chem. 109, 5124-5128 (2005).

[52] I. Nagypál, I. R. Epstein, Fluctuations and stirring rate effects in the chlorite-thiosulfate reaction, J. Phys. Chem. 90, 6285-6292 (1986).

[53] T. Bánsági Jr., D. Horváth, Á. Tóth, Convective instability of an acidity front in Hele-Shaw cells, Phys. Rev. E 68, 026303 (2003).

[54] T. Bánsági Jr., D. Horváth, Á. Tóth, Multicomponent convection in the chlorite-tetrathionate reaction, Chem. Phys. Lett. 384, 153-156 (2004).

[55] Tóth T., A reakcióedény paramétereinek hatása a közegmozgásra autokatalitikus frontokban, PhD disszertáció, Szeged (2009).

[56] A. Hanna, A. Saul, K. Showalter, Detailed studies of propagating fronts in the iodate oxidation of arsenous acid, J. Am. Chem. Soc. 104, 3838-3844 (1982). 
[57] G. A. Papsin, A. Hanna, K. Showalter, Bistability in the iodate oxidation of arsenous acid, J. Phys. Chem. 85, 2575-2582 (1981).

[58] P. De Kepper, I. R. Epstein, K. Kustin, Bistability in the oxidation of arsenite by iodate in a stirred flow reactor, J. Am. Chem. Soc. 103, 6121-6127 (1981).

[59] S. Kotrlỳ, L. Šůcha, Handbook of chemical equilibria in analytical chemistry, Ellis Horwood Limited, (1985).

[60] S. Dushman, The rate of the reaction between iodic and hydriodic acids, J. Phys. Chem. 8 , 453-482 (1904).

[61] J. R. Roebuck, The rate of the reaction between arsenious acid and iodine in acid solution; The rate of the reverse reaction; and the equilibrium between them, J. Phys. Chem. 6, 365-398 (1902).

[62] J. Harrison, K. Showalter, Propagating acidity fronts in the iodate-arsenous acid reaction, J. Phys. Chem. 90, 225-226 (1986).

[63] http://www.nobelprize.org/

[64] R. Rymden, J. Carlfors, P. Stilbs, Substrate binding to cyclodextrins in aqueous solution: a multicomponent self-diffusion study, J. Incl. Phen. 1, 159-167 (1983).

[65] S. Simova, S. Berger, Diffusion measurements vs. chemical shift titration for determination of association constants on the example of camphor-cyclodextrin complexes, J. Incl. Phen. 53, 163-170 (2005).

[66] K. F. Morris, C. S. Johnson, Diffusion-ordered two-dimensional nuclear magnetic resonance spectroscopy, J. Am. Chem. Soc. 114, 3139-3141 (1992).

[67] R. Huo, R. Wehrens, L. M. C. Buydens, Robust DOSY NMR data analysis, Chemometrics and Intelligent Laboratory Systems 85, 9-19 (2007).

[68] Batta Gy., Korszerú méréstechnikák az NMR-ben, Magyar Kém. F. Előadások 109-110, (3) 127-135 (2004).

[69] P. J. Hore, Mágneses magrezonancia, Nemzeti Tankönyvkiadó Rt. , Debrecen-Budapest (2004).

[70] J. P. Hornak, Teaching NMR using online textbooks, Molecules 4, 353-365 (1999).

[71] P. J. Hore, J. A. Jones, S. Wimperis, NMR: The toolkit, Oxford University Press, Oxford (2000).

[72] E. O. Stejskal, J. E. Tanner, Spin diffusion measurements: Spin echoes in the presence of timedependent field gradient, J. Chem. Phys. 42, 288-292 (1965). 
[73] Kropok A. Zs., Diffúzióállandó meghatározása PFGSE-NMR spektroszkópiával, diplomamunka, Szeged (2007).

[74] Pópity-Tóth É., Diffúzióállandók meghatározása pulzusgradiens spin echó NMR módszer segítségével, OTDK, Debrecen (2009).

[75] L. Rongy, N. Goyal, E. Meiburg, A. De Wit, Buoyancy-driven convection around chemical fronts traveling in covered horizontal solution layers, J. Chem. Phys. 127, 114710 (2007).

[76] O. Miholics, T. Rica, D. Horváth, Á. Tóth, Oscillatory and stationary convective patterns in a reaction driven gravity current, J. Chem. Phys. 135, 204501 (2011).

[77] Bánsági T., Konvektív instabilitás a klorit-tetrationát rendszerben, PhD disszertáció, Szeged (2004).

[78] Virányi Zs., Migráció- és diffúzióvezérelt instabilitás autokatalitikus ionreakcióban, PhD disszertáció, Szeged (2007).

[79] Rica T., Polimeroldatok hatása a közegmozgásra autokatalitikus frontokban, PhD disszertáció, Szeged (2011).

[80] H. S. Hele-Shaw, The flow of water, Nature 58, 33-36 (1898).

[81] M. Piotto, V. Saudek, V. Sklenár, Gradient-tailored excitation for single-quantum NMR spectroscopy of aqueous solutions, J. Bio. NMR 2, 661-665 (1992).

[82] J. L. Pons, T. E. Malliavin, M. A. Delsuc, Gifa V. 4: A complete package for NMR data set processing, J. Bio. NMR 8, 445-452 (1996).

[83] R. C. O. Sebastiao, C. N. Pacheco, J. P. Braga, D. Piló-Veloso, Diffusion coefficient distribution from NMR-DOSY experiments using Hopfield neural network, J. Magn. Res. 182, 22-28 (2006).

[84] Filákovics Zs., Laterális instabilitás a jodát-arzénessav rendszerben, diplomamunka, Szeged (2011).

[85] J. H. Merkin, I. Z. Kiss, Dispersion curves in the diffusional instability of autocatalytic reaction fronts, Phys. Rev. E. 72, 026219 (2005).

[86] H. E. Gottlieb, V. Kotlyar, A. Nudelman, NMR chemical shifts of common laboratory solvents as trace impurities, J. Org. Chem. 62, 7512-7515 (1997).

[87] http://www. chemexper.com/CRM/

[88] A. Kolozsi, A. Lakatos, G. Galbács, A. O. Madsen, E. Larsen, B. Gyurcsik, A pH-metric, UV, $N M R$, and $X$-ray crystallographic study on arsenous acid reacting with dithioerythritol, Inorg. Chem. 47, 3832-3840 (2008). 
[89] L. Rongy, G. Schuszter, Z. Sinkó, T. Tóth, D. Horváth, Á. Tóth, A. De Wit, Influence of thermal effects on buoyancy-driven convection around autocatalytic chemical fronts propagating horizontally, Chaos 19, 023110 (2009).

[90] G. G. Casado, L. Tofaletti, D. Müller, A. D'Onofrio, Rayleigh-Taylor instabilities in reactiondiffusion systems inside Hele-Shaw cell modified by the action of temperature, J. Chem. Phys. 126, 114502 (2007).

[91] I. Bou Malham, N. Jarrige, J. Martin, N. Rakotomalala, L. Talon, D. Salin, Lock-exchange experiments with an autocatalytic reaction front, J. Chem. Phys. 133, 244505 (2010).

[92] É. Pópity-Tóth, D. Horváth, Á. Tóth, The dependence of scaling law on stoichiometry for horizontally propagating vertical chemical fronts, J. Chem. Phys. 135, 074506 (2011).

[93] N. Jarrige, I. Bou Malham, J. Martin, N. Rakotomalala, D. Salin, L. Talon, Numerical simulations of a buoyant autocatalytic reaction front in tilted Hele-Shaw cells, Phys. Rev. E 81, 066311 (2010).

[94] J. Martin, N. Rakotomalala, L. Talon, D. Salin, Viscous lock-exchange in rectangular channels, J. Fluid Mech. 673, 132-146 (2011).

[95] L. Šebestíková, M. J. B. Hauser, Buoyancy-driven convection may switch between reactive states in three-dimensional chemical waves, Phys. Rev. E 85, 036303 (2012).

[96] K. Showalter, J. J. Tyson, Luther's 1906 discovery and analysis of chemical waves, J. Chem. Educ. 64, 742-744 (1987).

[97] J. H. Perry, Vegyészmérnökök kézikönyve 1., Múszaki könyvkiadó, Budapest (1968).

[98] T. Tóth, D. Horváth, Á. Tóth, Thermal effects in the density fingering of the chloritetetrathionate reaction, Chem. Phys. Lett. 442, 289-292 (2007).

[99] J. D‘Hernoncourt, A. Zebib, A. De Wit, Reaction driven convection around a stably stratifield chemical front, Phys. Rev. Lett. 96, 154501 (2006).

[100] J. D‘Hernoncourt, A. Zebib, A. De Wit, On the classification of buoyancy-driven chemohydrodynamic instabilities of chemical fronts, Chaos 17, 013109 (2007).

[101] H. Landolt, Ueber die zeitdauer der reaction zwischen jodsäure und schwefliger säure, Ber. Dtsch. Chem. Ges. 19, 1317-1365 (1886). 


\section{Köszönetnyilvánítás}

Ezúton szeretnék köszönetet mondani Dr. Dékány Imrének és Dr. Erdőhelyi Andrásnak, a Fizikai Kémiai és Anyagtudományi Tanszék korábbi, és jelenlegi vezetőjének, amiért lehetôvé tették számomra, hogy a tanszékükön végezhessem el a doktori disszertációm megírásához szükséges munkámat. Továbbá még megköszönöm a tanszék összes dolgozójának önzetlen segítségét.

Köszönettel tartozom témavezetőimnek, Dr. Tóth Ágotának és Dr. Horváth Dezsőnek, a rengeteg szakmai segítségért, amit annak érdekében nyújtottak, hogy a jelen munka elkészülhessen. Köszönöm az építő kritikáikat és végtelen türelmüket.

Szeretném megköszönni Dr. Véronique Pimienta, Dr. Király Zoltán és Dr. Páhi Barbara Annamária szakmai segítségét, amit a felületi feszültség mérések során nyújtottak. Továbbá köszönöm Dr. Bányai Istvánnak az NMR spektrumok felvételét és Dr. Martinek Tamásnak a NMR spektroszkóp kezelésének betanítását.

Külön köszönet illeti a csoportunkban dolgozó és korábban megforduló összes hallgatót, valamint Schuszter Gábor doktorandusztársamat a laboratóriumban kialakított kiváló légkörért. Köszönöm még Tóth-Szeles Eszter és Bohner Bíborka lelki támogatását, László Balázs kísérleti munkáját, valamint Bába Péternek, hogy rendelkezésemre bocsátotta a portói borral megtöltött pohárról készült felvételét.

Végül köszönöm szüleimnek és testvéremnek, hogy kitartásra sarkaltak, illetve, hogy mindig mellettem álltak az egyetemen eltöltött évek alatt. Külön köszönet illeti meg a férjemet, Gábort, amiért a legnehezebb pillanatokban is elviselt és erôt adott. A támogatásával és bíztatásával hozzásegített a céljaim eléréséhez. 